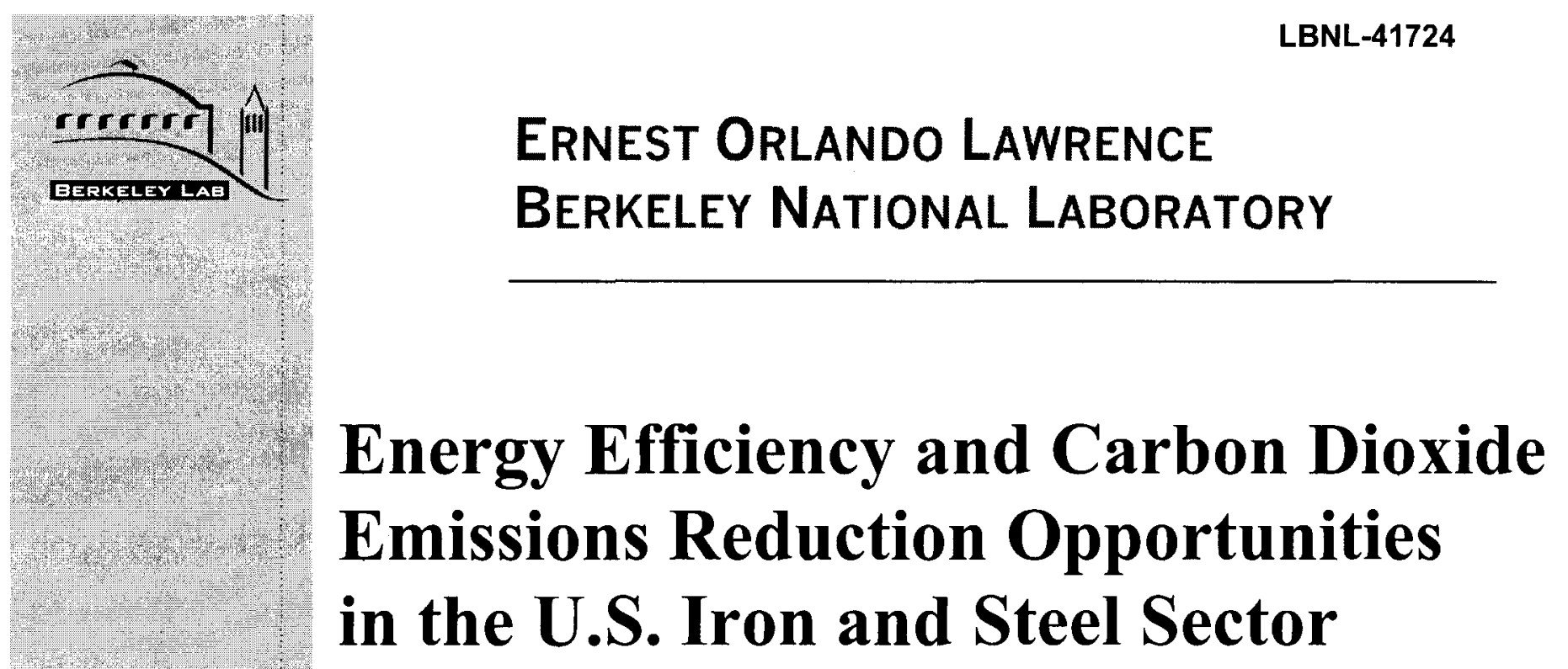

Ernst Worrell, Nathan Martin, and Lynn Price

\title{
Environmental Energy
}

Technologies Division

July 1999

This work was supported by the Climate Protection Division, Office of Air and

Radiation, U.S. Environmental Protection Agency through the U.S. Department of Energy under Contract No. DE-AC03-76SF00098. 


\section{Disclaimer}

This document was prepared as an account of work sponsored by the United States Government. While this document is believed to contain correct information, neither the United States Government nor any agency thereof, nor The Regents of the University of California, nor any of their employees, makes any warranty, express or implied, or assumes any legal responsibility for the accuracy, completeness, or usefulness of any information, apparatus, product, or process disclosed, or represents that its use would not infringe privately owned rights. Reference herein to any specific commercial product, process, or service by its trade name, trademark, manufacturer, or otherwise, does not necessarily constitute or imply its endorsement, recommendation, or favoring by the United States Government or any agency thereof, or The Regents of the University of California. The views and opinions of authors expressed herein do not necessarily state or reflect those of the United States Government or any agency thereof, or The Regents of the University of California.

Ernest Orlando Lawrence Berkeley National Laboratory is an equal opportunity employer. 
LBNL-41724

\title{
Energy Efficiency and Carbon Dioxide Emissions Reduction Opportunities in the U.S. Iron and Steel Sector
}

\author{
Ernst Worrell, Nathan Martin, Lynn Price
}

\author{
Energy Analysis Department \\ Environmental Energy Technologies Division \\ Ernest Orlando Lawrence Berkeley National Laboratory \\ University of California \\ Berkeley, California 94720
}

July 1999

This work was supported by the Climate Protection Division, Office of Air and Radiation, U.S. Environmental Protection Agency through the U.S. Department of Energy under Contract No. DE-AC03-76SF00098. 


\title{
Energy Efficiency and Carbon Dioxide Emissions Reduction Opportunities in the U.S. Iron and Steel Sector
}

\author{
Ernst Worrell, Nathan Martin, Lynn Price \\ Energy Analysis Department \\ Environmental Energy Technologies Division \\ Ernest Orlando Lawrence Berkeley National Laboratory
}

July 1999

\begin{abstract}
This paper presents an in-depth analysis of the U.S. iron and steel industry, identifying cost-effective energy and carbon dioxide emissions savings that can be achieved both today and in the near future. First we discuss trends and make international energy efficiency comparisons for this industry at the aggregate level (Standard Industrial Classification 331 and 332), which includes blast furnaces and steel mills (SIC 3312), electrometalurgical products (SIC 3313), and gray and ductile iron foundries (SIC 3321). Then we focus on a smaller portion of the industry, blast furnaces and steel mills (SIC 3312), for a detailed analysis of energy use and carbon dioxide emissions by process, specific energy efficiency technologies and measures to reduce energy use and carbon dioxide emissions, and the energy efficiency and carbon dioxide emissions reduction potential for steelmaking in the U.S. Reviewing the industry as a whole, we found that U.S. steel plants are relatively old and production has fluctuated dramatically in the recent past. Metallurgical coal is still the primary fuel for the sector but gas and electricity use has been increasing. Between 1958 and 1994, physical energy intensity for iron and steelmaking (SIC 331, 332) dropped $27 \%$, from $35.6 \mathrm{GJ} / \mathrm{t}$ to $25.9 \mathrm{GJ} / \mathrm{t}$, while carbon dioxide intensity (carbon dioxide emissions expressed in tonnes of carbon per tonne of steel) dropped $39 \%$, from $0.82 \mathrm{tC} / \mathrm{t}$ to $0.50 \mathrm{tC} / \mathrm{t}$. Compared to other large steel producers, the U.S. still tends to have higher energy intensities and has a large technical potential to achieve best practice levels of energy use for steel production. In our detailed analysis of the U.S. iron and steel sector (SIC 3312), we examined 48 specific energy efficiency technologies and measures and estimated energy savings, carbon dioxide emissions reductions, investment costs, and operation and maintenance costs for each of these measures. Based on this information, we constructed an energy conservation supply curve for U.S. iron and steelmaking which found a total cost-effective reduction potential of $3.8 \mathrm{GJ} / \mathrm{t}$, equivalent to an achievable energy savings of $18 \%$ of 1994 U.S. iron and steel energy use and a roughly equivalent savings (19\%) of 1994 U.S. iron and steel carbon dioxide emissions.
\end{abstract}




\section{Table of Contents}



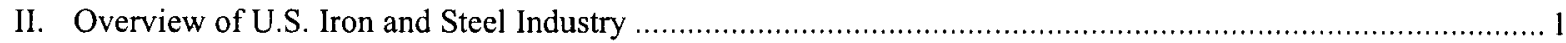

III. Energy Use and Carbon Dioxide Emissions in the U.S. Iron and Steel Industry (SIC 331, 332) .................. 3

Historical Energy Use and Carbon Dioxide Emissions Trends ............................................ 3

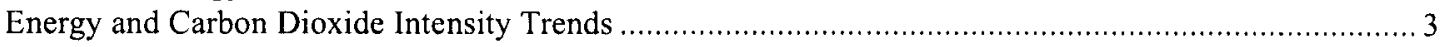

IV. International Comparison of U.S. Energy Use for Steelmaking ..................................................... 4

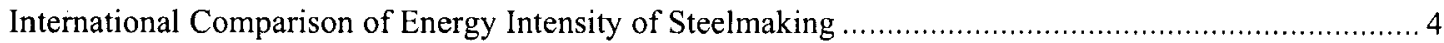



V. 1994 Baseline Energy Use and Carbon Dioxide Emissions for Energy Use in U.S. Blast Furnaces and Steel

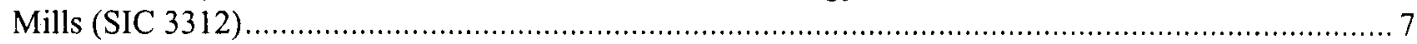

Energy Use and Carbon Dioxide Emissions by Process in U.S. Steelmaking ................................... 7

VI. Technologies and Measures to Reduce Energy Use and Carbon Dioxide Emissions ................................... 9

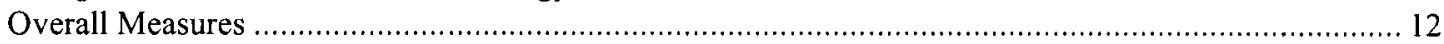

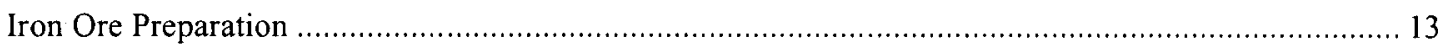

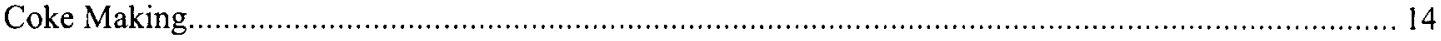





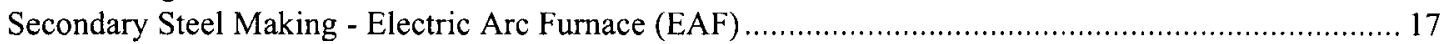

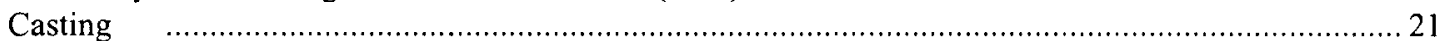



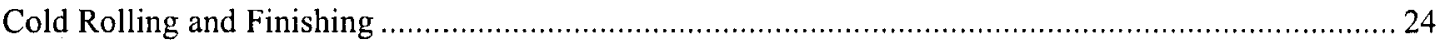

VII. Energy Efficiency and Carbon Dioxide Emissions Reduction Potential for Steelmaking in the U.S..............26

Energy Conservation Supply Curves................................................................................2 26

Energy Conservation Supply Curve for U.S. Integrated Steelmaking ............................................2 27

Energy Conservation Supply Curve for U.S. Secondary Steelmaking ...........................................2 28

Energy Conservation Supply Curve for Total Steelmaking (Blast Furnaces and Steel Mills - SIC 3312). 29



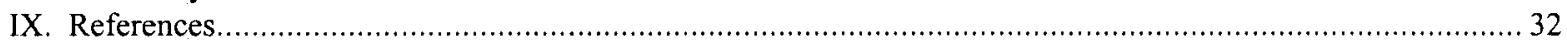

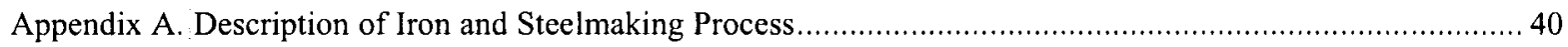

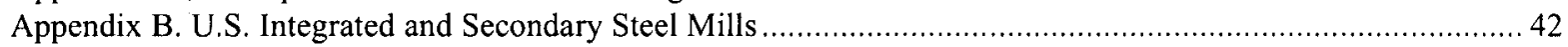

Appendix C. Comparison of Economic and Physical Indicators of Energy Intensity in Steel Production............. 48

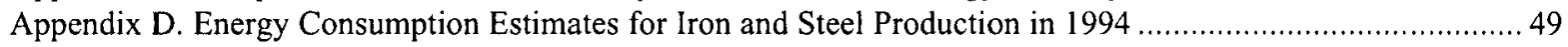

Appendix E. Advanced Technologies for Energy Efficiency Improvement in the U.S. Steel Industry ................. 51

\section{Tables}

Table 1. Best Practice Weighting Factors for Various Steel Products .................................................... 6

Table 2. Energy Use and Carbon Dioxide Emissions by Process in U.S. Steel Production, 1994 .......................... 7

Table 3. State-of-the-Art Energy Efficiency Measures in the U.S. Iron and Steel Industry. ................................... 9

Table 4. Energy Savings, Costs, and Carbon Dioxide Emissions Reductions for Energy-Efficiency Technologies and Measures Applied to Integrated Steel Production in the U.S. in 1994 ................................. 10

Table 5. Energy Savings, Costs, and Carbon Dioxide Emissions Reductions for Energy-Efficiency Technologies and Measures Applied to Secondary Steel Production in the U.S. in 1994 ..................................... 11

Table 6. Cost of Conserved Energy for Selected Measures in Integrated Steelmaking ...................................28

Table 7. Cost of Conserved Energy for Selected Measures in Secondary Steelmaking......................................29

Table 8. Summary of Cost-Effective 1994 Energy Savings and Carbon Dioxide Emission Reductions................. 30

Table B-1. 1997 Blast Furnaces in U.S. Integrated Steel Mills. ..............................................................42



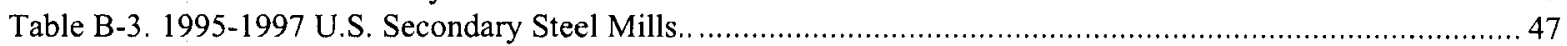

Table D-1. Sources for Estimating Energy Use and Carbon Dioxide Emissions by Process in U.S. Steel Production, 1994. 


\section{Figures}

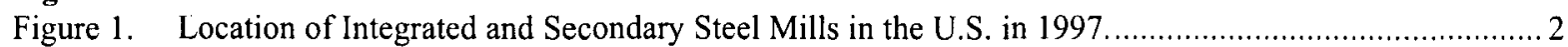

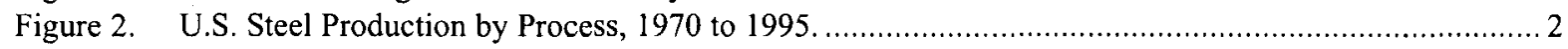

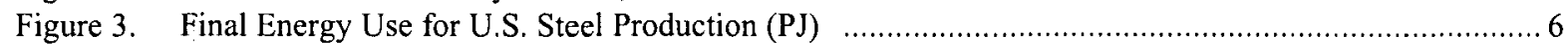

Figure 4. Carbon Dioxide Emissions from Energy Used For U.S. Steel Production (MtC) ........................... 3

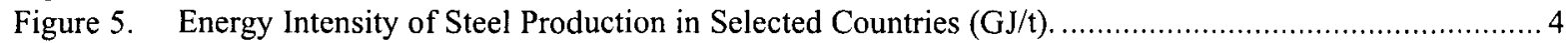

Figure 6. Comparison of Actual and Best Practice Energy Intensities for Selected Countries, 1991 ................. 5

Figure 7. Relative Changes in Energy Intensity Between 1980 and 1991 and the Contribution of Structure and

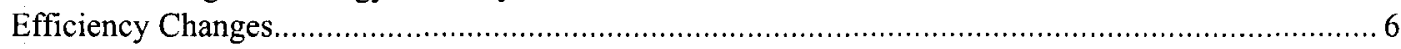

Figure 8. Energy Conservation Supply Curve for Integrated Steelmaking............................................27

Figure 9. Energy Conservation Supply Curve for Secondary Steelmaking .......................................... 29

Figure 10. Energy Conservation Supply Curve for Total Steelmaking, ...............................................30

Figure A-1. Iron and Steel Production Routes ........................................................................4 40

Figure C-1. Comparison of Physical and Economic Energy Intensity Indicators for Steel Production in the U.S., 1985-1991. 


\section{Introduction}

The manufacturing sector consumed 23 EJ of primary energy in the United States in 1994, almost one-quarter of all energy consumed that year (U.S. DOE, EIA 1997). ' Within manufacturing, a subset of raw materials transformation industries (primary metals, pulp and paper, cement, chemicals, petroleum refining) require significantly more energy than other manufacturing industries.

This report presents an in-depth analysis of one of these energy-intensive industries -- iron and steel -- identifying energy savings and carbon dioxide emissions reductions potentials. We analyze the iron and steel industry on two levels. First, when reviewing industry trends in Sections II and III and when making international comparisons in Section IV, we discuss this industry at the aggregate level (Standard Industrial Classification 331 and 332), which includes blast furnaces and steel mills (SIC 3312), electrometallurgical products (e.g. ferroalloys) (SIC 3313), and gray and ductile iron foundries (SIC 3321). ${ }^{2}$ Second, we focus on a smaller portion of the industry, blast furnaces and steel mills (SIC 3312) for a detailed analysis of energy use and carbon dioxide emissions by process (Section $\mathrm{V}$ ), specific energy efficiency technologies and measures to reduce energy use and carbon dioxide emissions (Section VI), and the energy efficiency and carbon dioxide emissions reduction potential for steelmaking in the U.S. (Section VII).

\section{Overview of U.S. Iron and Steel Industry}

The U.S. iron and steel industry is made up of integrated steel mills that produce pig iron from raw materials (iron ore, coke) using a blast furnace and steel using a basic oxygen furnace (BOF) and secondary steel mills that produce steel from scrap steel, pig iron, or direct reduced iron (DRI) using an electric arc furnace (EAF). The majority of steel produced in the U.S. is from integrated steel mills, although the share of secondary steel mills (or "minimills") is increasing, growing from 15\% of production in 1970 to $40 \%$ in 1995 (AISI, 1997).

There were 142 operating steel plants in the U.S. in 1997 (see Figure 1). At that time, there were 14 integrated steel companies operating 20 integrated steel mills with a total of 40 blast furnaces (I\&SM, 1997a). These mills are concentrated in the Great Lakes region, near supplies of coal and iron ore and near key customers such as the automobile manufacturers. The blast furnaces in these mills range in age - accounting for furnace rebuilds - from 2 to 67 years, with an average age of 29 years. Production rates per plant vary between 0.5 and 3.1 million metric tons (Mt) per year. Total production of U.S. blast furnaces in 1997 was slightly over $54 \mathrm{Mt}$ (I\&SM, 1997a).

Secondary steel mills are located throughout the U.S, with some concentration in the South, near waterways for shipping and in areas with lower-cost electricity and labor (U.S. DOE, EIA, 1996; Hogan, 1987). In 1997 there were 85 secondary steel companies operating 122 minimills with 226 EAFs. These facilities are spread throughout 35 states, with the largest number of plants in Pennsylvania, Ohio, and Texas. The electric arc furnaces at these mills range in age from 0 (just starting production in 1997) to 74 years, with an average age of 24 years. Total annual nominal capacity listed in 1994 was $50.4 \mathrm{Mt}$ and the average power consumption is $480 \mathrm{kWh} / \mathrm{t}$ (436 $\mathrm{kWh} / \mathrm{short}$ ton) (I\&SM, 1997b). Between 1995 and 1997 an additional $12 \mathrm{Mt}$ of electric arc furnace capacity was built. Appendix B provides more detailed information on U.S. integrated and secondary steel mills.

Figure 2 shows that steel production in the U.S. has fluctuated dramatically since 1970, when production was just below $120 \mathrm{Mt}$. Production peaked at $136 \mathrm{Mt}$ in 1973 and fluctuated between 100 and $130 \mathrm{Mt}$ until it crashed to 68 Mt in 1982 as a result of a dramatic number of integrated mill closures. Since 1982, production has grown slowly, with two major declines in 1985-86 and 1991. In 1995, production reached $95 \mathrm{Mt}$. During this period, primary steel production using inefficient open hearth furnaces dropped from $44 \mathrm{Mt}$ in 1970 to $6 \mathrm{Mt}$ in 1982 and was completely phased out by 1992 . Primary steel production using a basic oxygen furnace fluctuated between 40 and $75 \mathrm{Mt}$ over the period. Secondary production more than doubled, growing from 18 to $38 \mathrm{Mt}$ between 1970 and 1995 (AISI, 1997).

\footnotetext{
${ }^{1}$ To convert from EJ to Quads, from PJ to TBtu, and from GJ to MBtu, multiply by 0.95 ; to convert from metric tons to short tons, multiply by 1.1 ; to convert from $\mathrm{GJ} /$ metric ton to MBtu/short ton, multiply by 0.86 .

${ }^{2}$ We focus on SIC 3312, 3313, and 3321 because energy consumption values are provided for these subsectors only by the U.S. Energy Information Administration.
} 
Figure 1. Location of Integrated and Secondary Steel Mills in the U.S. in 1997.

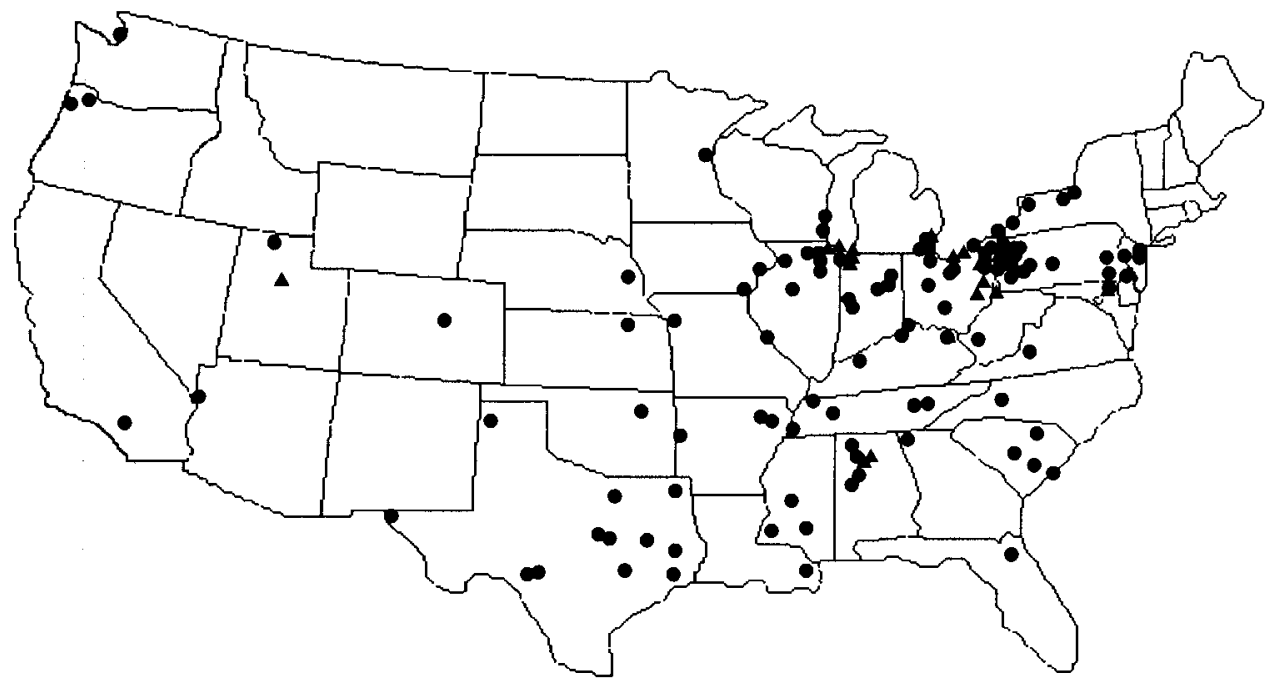

- Integrated Steel Production

Secondary Steel Production

Source: I\&SM, 1997a; I\&SM 1997b; Hogan and Koeble, 1996a.

Figure 2. U.S. Steel Production by Process, 1970 to 1995.

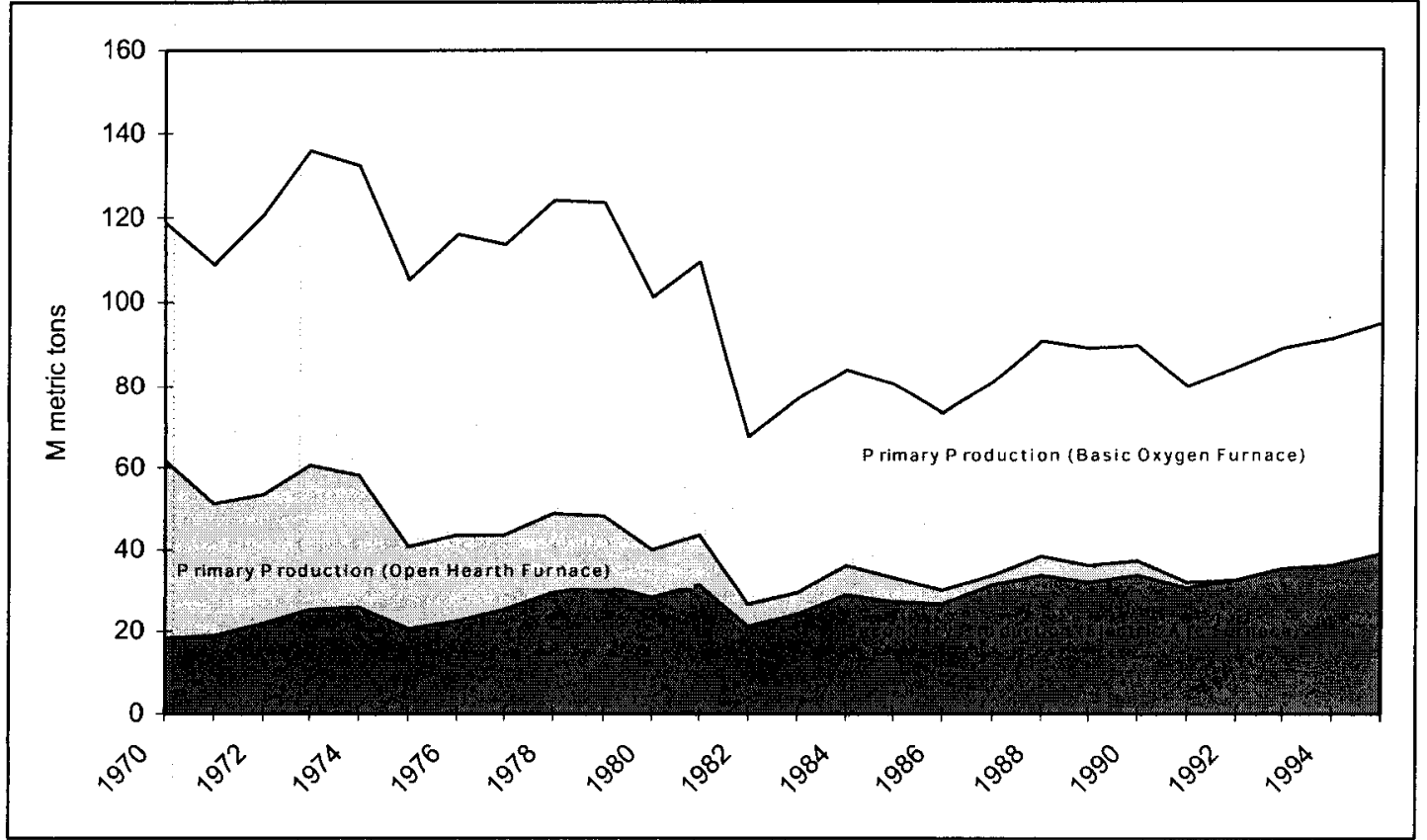

Source: AISI, various years. 


\title{
III. Energy Use and Carbon Dioxide Emissions ${ }^{3}$ in the U.S. Iron and Steel Industry (SIC 331, 332)
}

\author{
Historical Energy Use and Carbon Dioxide Emissions Trends
}

Final energy use for the iron and steel industry (SIC 331, 332) fluctuated significantly between 1958 and 1994 , starting at $2.6 \mathrm{EJ}$ (2.8 EJ primary energy) in 1958, climbing to $3.9 \mathrm{EJ}$ (4.4 EJ primary energy) in 1973, dropping to $1.9 \mathrm{EJ}$ (2.3 EJ primary energy) in 1982, and remaining level at $1.9 \mathrm{EJ}$ of final energy (2.4 EJ primary energy) in 1994 (see Figure 3). ${ }^{4}$ Between 1958 and 1994 the share of coal and coke used as energy sources dropped from about $75 \%$ to $57 \%$ of total fuels, followed by a drop in the share of oil from $10 \%$ to $3 \%$. The share of natural gas used in the industry increased from $10 \%$ to $28 \%$. The share of electricity increased from $4 \%$ to $11 \%$ during the same period, in large part due to increased secondary steel production. Carbon dioxide emissions trends (expressed in million metric tonnes $(\mathrm{MtC}$ ) of carbon) have followed energy use trends (see Figure 4), with emissions of 64 $\mathrm{MtC}$ in 1958, $96 \mathrm{MtC}$ in 1973, and $45 \mathrm{MtC}$ in 1994 (LBNL, IES, 1998). ${ }^{5}$

Figure 3. Final Energy Use for U.S. Steel Production (PJ) Used

\section{Energy Use}

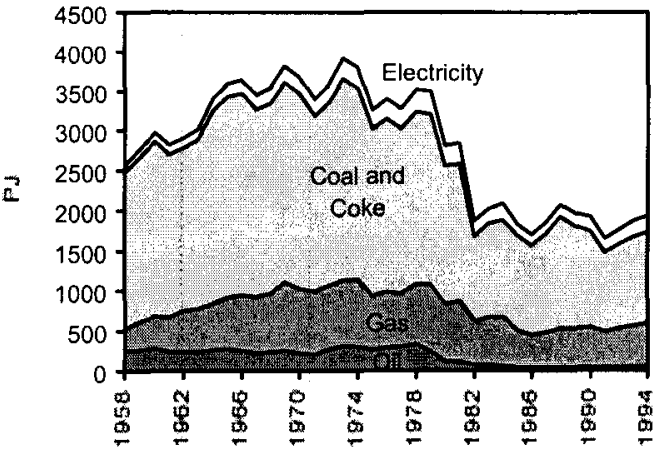

Figure 4. Carbon Dioxide Emissions from Energy For U.S. Steel Production (MtC)

\section{Carbon Dioxide Emissions}

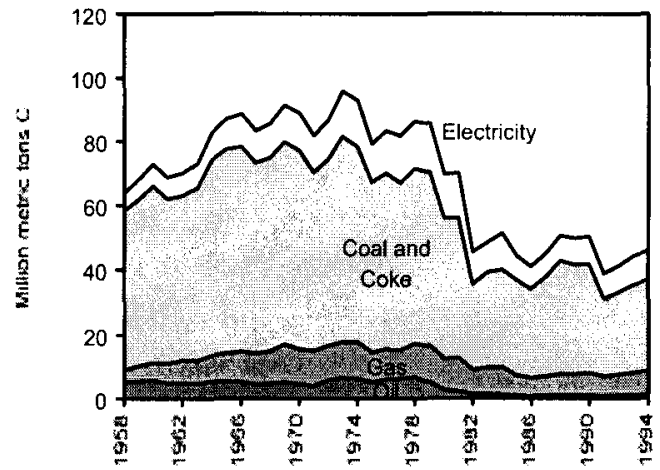

Source: LBNL, IES, 1998.

\section{Energy and Carbon Dioxide Intensity Trends}

Physical energy intensity of U.S. steel production, defined as primary energy use for SIC 331 and 332 per metric ton of steel produced, dropped $27 \%$, from $35.6 \mathrm{GJ} / \mathrm{t}$ to $25.9 \mathrm{GJ} / \mathrm{t}$, between 1958 and $1994 .^{6,7}$ Decomposition analyses indicate that about two-thirds of the decrease between 1980 and 1991 was due to efficiency improvements, while the remainder was due to structural changes (Worrell et al., 1997a). Carbon dioxide intensity dropped from $0.82 \mathrm{tC} / \mathrm{t}$ to $0.50 \mathrm{tC} / \mathrm{t}$, during this period, reflecting the general decrease in energy use per tonne of steel produced

\footnotetext{
${ }^{3}$ In this report carbon dioxide emissions are expressed in metric tons carbon. To convert to carbon dioxide multiply by $44 / 12$.

${ }^{4}$ Primary energy is calculated using a conversion rate from final to primary electricity of 3.08 , reflecting the difference between an average power plant heat rate of $10,500 \mathrm{Btu} / \mathrm{kWh}$ and a site rate of $3412 \mathrm{Btu} / \mathrm{kWh}$, including transmission and distribution losses.

${ }^{5}$ The carbon conversion factors used for calculating carbon emissions from energy consumption are taken from U.S. DOE, EIA, 1996. Electricity conversion factors vary annually based on the fuel mix used for power generation. Roughly $1 \%$ to $2 \%$ of the carbon emissions attributed to OHF and BOF production is fixed in the steel, but we have not made the subtraction here for the overall figure.

${ }^{6}$ Throughout this report, we define energy intensity in terms of physical output rather than economic output. Worrell et al. (1997a) demonstrated that economic indicators of energy intensity do not always accurately reflect physical trends and concluded that physical energy intensity measurements should be used when possible (Worrell et al., 1997a). Appendix C provides more information regarding comparisons of economic and physical indicators.

Energy consumption values from 1991 through 1994 include SIC 3312 (blast furnaces and steel mills) 3313 (electrometallurgical products) and 3321 (gray and ductile iron foundries) in order to better match historical aggregate data. Due to limited coverage in the U.S. DOE, EIA Manufacturing Energy Consumption Survey, data for 1985 through 1990 reflect energy use for SIC 3312 only, and therefore may be roughly 5-8\% lower than energy use for the more aggregate SIC $331-332$.
} 
as well as fuel switching. The most important change was the growing use of scrap-based electric arc furnaces for secondary steel production, which grew from $17 \%$ to $39 \%$ of total steel production during this period. Efficiency improvement can be explained mainly by the increased use of continuous casting, which grew from $0 \%$ in 1971 to $89 \%$ in 1994, and the closing of inefficient open hearth furnace steelmaking, which dropped from $30 \%$ in 1971 to $0 \%$ after 1991. In addition, the increased use of pellets as blast furnace feed contributed to the energy savings (Price et al., 1997; IISI, 1996b).

Despite these overall improvements, energy intensity of steel production in the U.S. increased slightly between 1991 and 1994, growing from $25.2 \mathrm{GJ} / \mathrm{t}$ to $25.9 \mathrm{GJ} / \mathrm{t}$, reversing the long-term downward trend ${ }^{8}$ Based on trends in three key areas (increased share of electric arc furnaces from $38 \%$ to $39 \%$, retirement of all remaining open hearth furnaces, and increase in the use of continuous casting from $76 \%$ in 1991 to $89 \%$ in 1994), this increase is unexpected. Trends that may have contributed to the increased energy use include a move toward more extensively treated, higher quality cold rolled steel and increased capacity utilization leading to the use of older, less-efficient integrated steel mills (Price et al., 1997).

\section{International Comparison of U.S. Energy Use for Steelmaking}

\section{International Comparison of Energy Intensity of Steelmaking}

Energy intensities for eight of the world's largest steel-producing countries are plotted in Figure 5 and show a general downward trend in most countries between 1971 and 1994. ${ }^{9}$ Iron and steel production is least energyintensive in S. Korea, Germany, Japan, and France and most energy-intensive in China. ${ }^{10}$ Energy intensity of steelmaking in the U.S. dropped over $20 \%$ between 1971 and 1994. As noted above, the 1994 energy intensity is slightly higher than that in 1991, indicating a change in the longer-term trend of decreasing energy use per tonne of steel. Japan, Poland, and France also show a slight increase in energy intensity in recent years (Price et al., 1997).

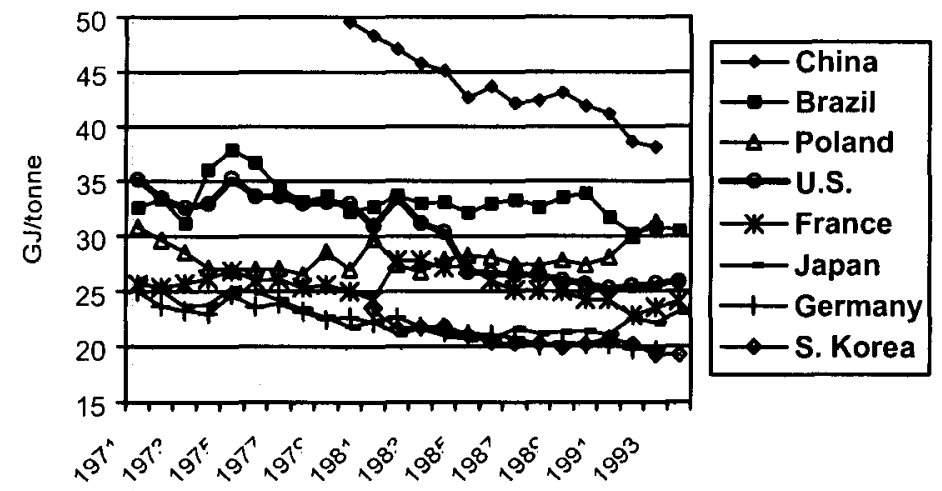

Figure 5. Energy Intensity of Steel Production in Selected Countries (GJ/t). Source: Price et al., 1997.

\footnotetext{
${ }^{8}$ These energy intensity values are calculated using energy use data from the U.S. Manufacturing Energy Consumption Survey (MECS) and accounts for energy used in coke production and for coke shipments (U.S. DOE, EIA, 1994; U.S. DOE, EIA, 1997). We note that energy use data of the American Iron and Steel Institute show an $8 \%$ decline in primary energy intensity between 1990 and 1994 (U.S. DOE, OIT, 1996).

${ }^{9}$ The former Soviet Union is among the top steel producing countries worldwide, but is not included in this comparison due to the lack of sector-specific energy use data.

${ }^{10}$ Chinese steel industry energy use has been lowered by six percent to correct for the fact that energy is also used for so-called "non-productive use" such as residential energy use by employees and energy use for mining of raw materials (Ross and Feng, 1991).
} 


\section{Best Practice Comparison}

To provide an indication of how the energy intensity of the total iron and steel sector in the U.S. compares to operating plants with the lowest energy intensities globally, we first determined the "best practice" energy intensities for specific processes at plants in operation in The Netherlands and Germany. Best practice reflects the lowest specific energy consumption required to produce certain steel products at actual plants. Table I provides the best practice weighting factors which are based on 1988 energy intensity values for basic oxygen furnace slab production, electric arc furnace slab production, hot rolling, and cold rolling in these plants (Worrell et al., 1997a). We then calculated the energy intensity that would have been achieved in the U.S. in both 1991 and 1994 to produce the same mix of products that was actually produced in those years using the 1988 "best practice" energy intensities.

Figure 6 shows this comparison of the actual average energy intensities of all operating plants and the "best practice" energy intensities for the U.S. in 1991 and 1994 as well as for six other countries in 1991. The x-axis indicates the share of secondary (EAF) steelmaking in each country; EAF steelmaking is a much less energyintensive process but also produces a different quality of steel product than integrated steelmaking. Countries with a higher share of EAF process would be expected to have lower overall energy intensities for production of steel ${ }^{11}$. However, energy use is also affected by the production of energy-intensive products like cold rolled steel. Figure 6 also accounts for differences in product mix.

As shown in Figure 6, China, Brazil, Poland, and the U.S. have the largest potential energy savings, while France, Japan, and especially Germany have lower potentials. ${ }^{12}$ The difference in the U.S. best practice and actual energy intensities was about $11 \mathrm{GJ} / \mathrm{t}$ (or 43\%) in both 1991 and 1994, despite the fact that the U.S. had the highest share of EAF steelmaking ( $38 \%$ in $1991,39 \%$ in 1994). When compared to best practice in other countries, U.S. energy use per tonne of steel is high in the blast furnace, the basic oxygen furnace (due to the lack of basic oxygen furnace gas recovery), the reheating furnace, and in the hot strip mill (Worrell et al., 1993; U.S. DOE, OIT, 1996; IISI, 1996b).

Figure 6. Comparison of Actual and Best Practice Energy Intensities for Selected Countries, 1991 (and 1994 for



\footnotetext{
11 Bock et al. (1994) using a different definition of best practice, studied electricity intensities in U.S. EAF mills and found a potential reduction in electricity intensity of around $16 \%$ for mills in 1988 from average to best practice levels.

${ }_{12}^{12}$ Potential energy savings for Germany may have increased since 1991 due to the unification with former East Germany.
} 
Source: Price et al., 1997.

Table 1. Best Practice Weighting Factors for Various Steel Products.

\begin{tabular}{l|c|c|c}
\hline Product & $\begin{array}{c}\text { Fuel } \\
(\mathrm{GJ} / \mathrm{t})\end{array}$ & $\begin{array}{c}\text { Electricity } \\
(\mathrm{GJ} / \mathrm{t})\end{array}$ & $\begin{array}{c}\text { Primary energy } \\
(\mathrm{GJ} / \mathrm{t})\end{array}$ \\
\hline${\text { Basic Oxygen Furnace }- \text { Slab }^{14}}^{14}$ & 14.24 & 0.36 & 15.3 \\
Electric Arc Furnace - Slab $^{15}$ & 0.79 & 1.52 & 5.4 \\
Hot Rolling $^{16}$ & 1.82 & 0.37 & 2.9 \\
Cold Rolling $^{17}$ & 1.10 & 0.53 & 2.7 \\
\hline
\end{tabular}

Figure 7 shows the relative changes in primary energy intensity in seven countries between 1980 and 1991 and decomposes those changes into the portion attributed to efficiency improvement and that attributed to structural change (changes in process and product mix). The first bar for each country represents the aggregate change in physical energy intensity between 1980 and 1991 while the second and third bars represent the contribution of efficiency and structural changes, respectively, to the overall change in physical energy intensity during the period. Energy use for steel production in the U.S. dropped 17\% from 1980 to 1991; of this, a decline of $6 \%$ was due to structural changes like the shift to EAFs and $11 \%$ was due to efficiency improvements (Worrell et al., 1997a). This analysis suggests that energy efficiency, as opposed to overall energy intensity, improved at a rate of about $1 \%$ per year in the U.S. over the period 1980 to 1991 .

Figure 7. Relative Changes in Energy Intensity Between 1980 and 1991 and the Contribution of Structure and Efficiency Changes.

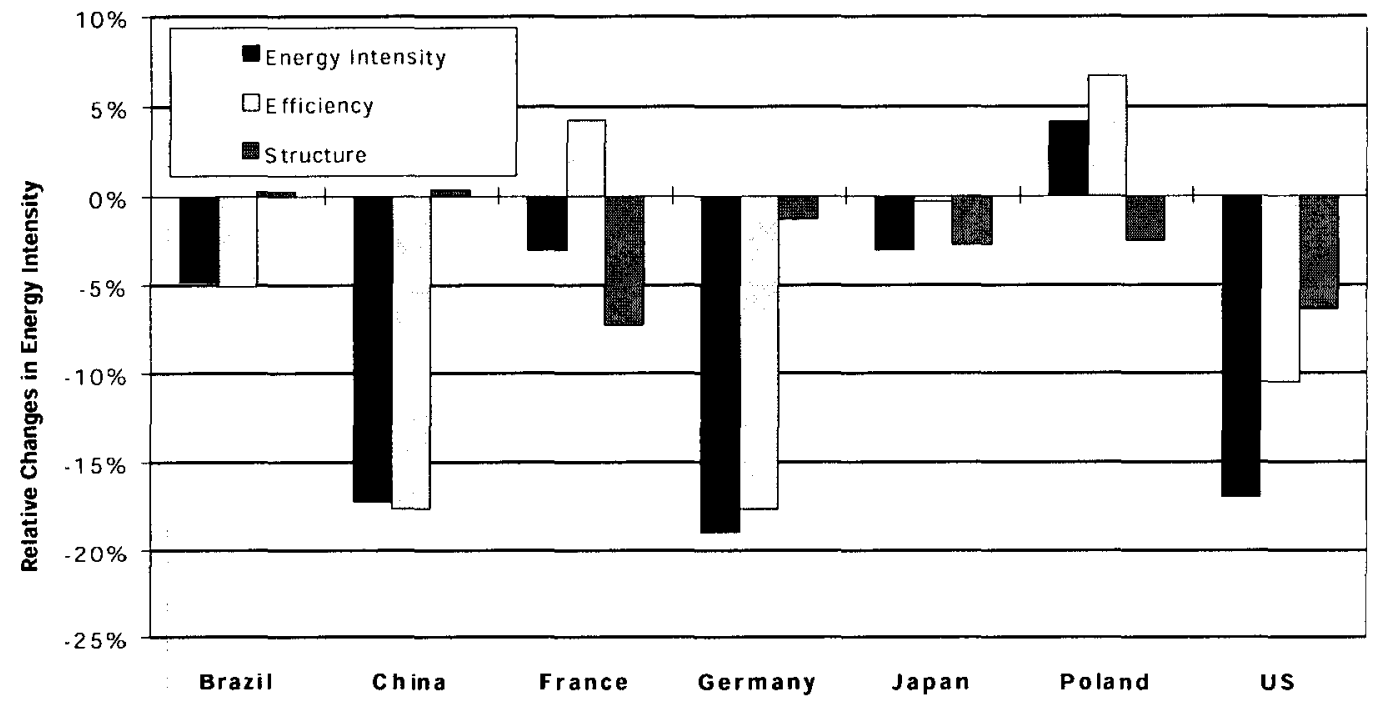

${ }^{13}$ Calculated intensity assuming an electricity generation efficiency of $33 \%$.

${ }^{14}$ Equivalent to the 1988 energy intensity of an integrated steel plant in The Netherlands, assuming $10 \%$ scrap addition in the BOF (Worrell et al., 1993).

${ }^{15}$ Equivalent to the energy intensity of an EAF plant in Germany (Teoh, 1989) and the energy intensity for continuous casting equivalent to the integrated steel plant (Worrell et al., 1993).

${ }^{16}$ Equivalent to the 1988 energy intensity of a hot strip mill at an integrated steel plant in The Netherlands (Worrell et al., 1993). The energy intensity of wire rod production is comparable to the given energy intensity (IISI, 1982).

${ }^{17}$ Equivalent to the 1988 energy intensity of a cold rolling mill at an integrated steel plant (Worrell et al., 1993) 
Source: Worrell et al., 1997a.

\title{
V. 1994 Baseline Energy Use and Carbon Dioxide Emissions for Energy Use in U.S. Blast Furnaces and Steel Mills (SIC 3312)
}

\author{
Energy Use and Carbon Dioxide Emissions by Process in U.S. Steelmaking
}

For our detailed analysis of the U.S. iron and steel industry, we focus on a smaller portion of the industry, blast furnaces and steel mills (SIC 3312). The main energy-using processes for integrated steel production are sintermaking, cokemaking, ironmaking, steelmaking. ${ }^{18}$ Only the steelmaking step is used for production of secondary steel. ${ }^{19}$ Following steel production, energy is used for casting, hot rolling, cold rolling, and finishing. In 1994 , integrated steel mills in the U.S. produced 55.4 Mt of steel and secondary steel mills produced $35.87 \mathrm{Mt}$, for a total U.S. production of $91.3 \mathrm{Mt}$. Table 2 provides an estimate of the energy use and carbon dioxide emissions from energy use by process for production of steel in the U.S. in 1994. ${ }^{20}$ Primary energy use for integrated steelmaking was about three times greater than energy use in secondary steelmaking, consuming 1439 PJ compared to $425 \mathrm{PJ}$. The primary energy intensity of integrated and secondary steel production in 1994 was 26.0 $\mathrm{GJ} / \mathrm{t}$ and $11.8 \mathrm{GJ} / \mathrm{t}$, respectively, for a total sector primary energy intensity of $20.4 \mathrm{GJ} / \mathrm{t}^{21}$ Total carbon dioxide emissions from steelmaking in 1994 were $34.4 \mathrm{MtC}$, with $80 \%$ of these emissions from integrated steelmaking. The carbon dioxide intensity of integrated steelmaking was $0.5 \mathrm{tC} / \mathrm{t}$ crude steel while the carbon dioxide intensity for secondary steelmaking was $0.2 \mathrm{tC} / \mathrm{t}$ crude steel, resulting in a total sector carbon dioxide intensity of $0.4 \mathrm{tC} / \mathrm{t}$ crude steel.

Table 2. Energy Use and Carbon Dioxide Emissions by Process in U.S. Steel Production. 1994.

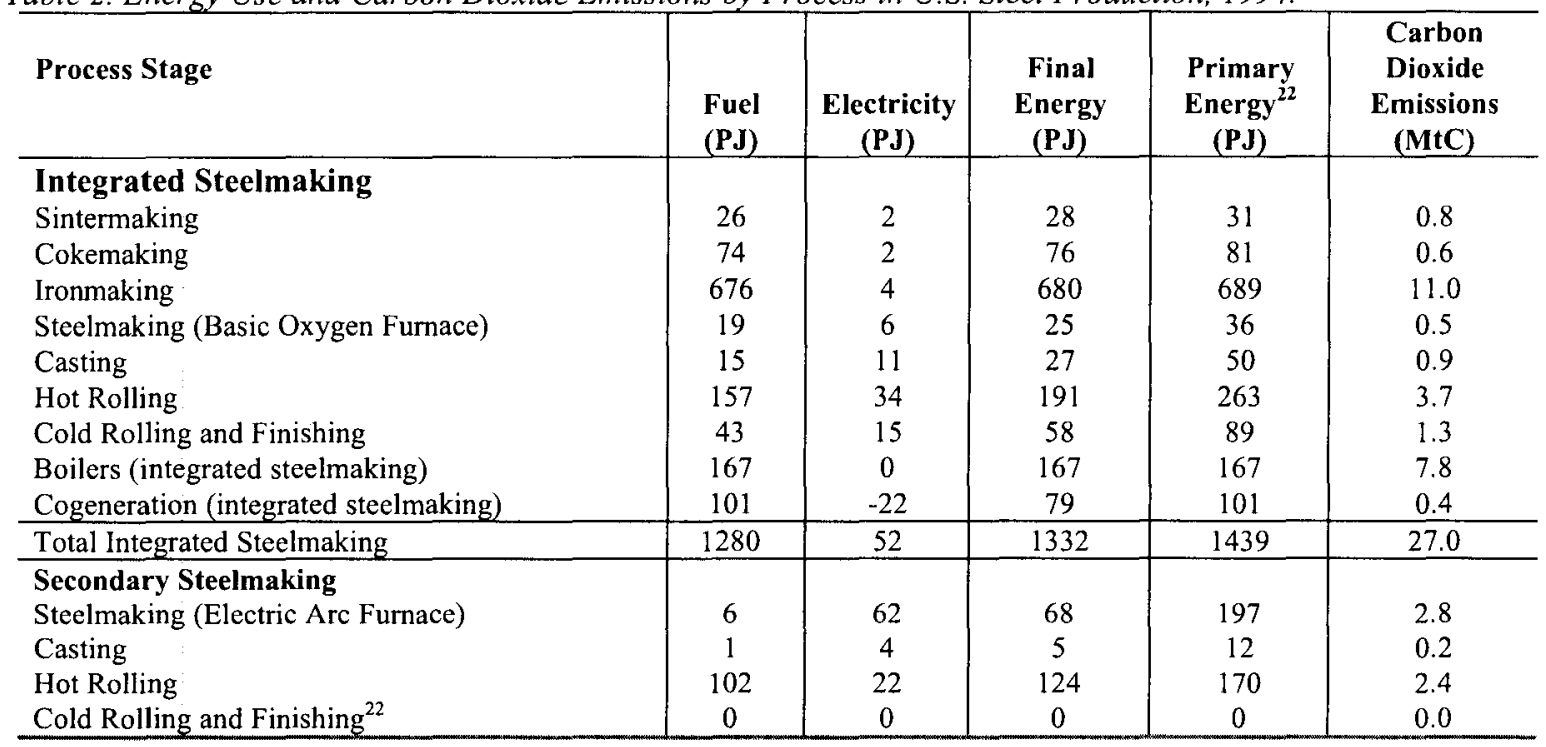

\footnotetext{
${ }^{18}$ Pelletizing, the production of iron ore pellets, is normally undertaken at the mining site and is not included in our baseline.

${ }^{19}$ Secondary steel is produced from scrap and/or direct reduced iron (DRI, also called sponge iron). While DRI production is growing, it comprised only $2 \%$ of secondary steel inputs in 1994 (AISI, 1997).

${ }^{20}$ Energy consumption data in Table 2 are based on data from the American Iron and Steel Association's Annual Statistical Report (AISI, 1997). When data on specific sub-processes were not available, consumption estimates were based on process energy intensity estimates and throughput from available literature (especially, U.S. DOE, OIT, 1996). Oxygen production is not included in the energy use estimates. Appendix D provides details on the estimation made for each process step.

${ }^{21}$ Primary energy is calculated using a conversion rate from final to primary electricity of 3.08 , reflecting the difference between an average plant heat rate of $10,500 \mathrm{Btu} / \mathrm{kWh}$ and a site rate of $3412 \mathrm{Btu} / \mathrm{kWh}$, including transmission \& distribution losses.

${ }^{22}$ In 1994, no EAF plants used a cold rolling mill. Since then, however, at least 3 mills are using this process.
} 


\begin{tabular}{l|c|c|c|c|c}
\hline Boilers (secondary steelmaking) & 42 & 0 & 42 & 42 & 2.0 \\
Cogeneration (secondary steelmaking) & 11 & -2 & 9 & 11 & 0.04 \\
\hline Total Secondary Steelmaking & 162 & 85 & 248 & 425 & 7.4 \\
\hline Total Primary and Secondary Steelmaking & $\mathbf{1 4 4 3}$ & $\mathbf{1 3 7}$ & $\mathbf{1 5 8 0}$ & $\mathbf{1 8 6 4}$ & $\mathbf{3 4 . 4}$ \\
\hline
\end{tabular}

${ }^{23}$ In EAF mills steam is used for the vacuum degasser and for the production of specialty steels. 


\section{Technologies and Measures to Reduce Energy Use and Carbon Dioxide Emissions}

To analyze the potential for reducing energy use and carbon dioxide emissions from steelmaking in the U.S., we compiled information on the costs, energy savings, and carbon dioxide emissions reductions of a number of technologies and measures. Below we provide a detailed description of each of these technologies and measures along with associated costs and energy and other related information. These technologies and measures fall into two categories: state-of-the-art measures that are currently in use in steel mills worldwide (see Table 3) and advanced measures that are either only in limited use or are near commercialization (see Appendix E). We focus on retrofit measures using commercially available technologies, but many of these technologies are applicable for new plants as well. For each technology or measure, we estimate costs and energy savings per tonne of crude steel produced in 1994. We then calculate carbon dioxide emissions reductions based on the fuels used at the process step to which the technology or measure is applied. Table 4 provides total production, fuel, electricity, and primary energy savings per tonne of crude steel; annual operating costs; capital costs per tonne of crude steel; percentage of production to which the measure is applied nationally; and carbon dioxide emissions reductions for each measure applied to the production of primary steel in an integrated mill. Table 5 provides similar information for production of secondary steel.

Table 3. State-of-the-Art Energy Efficiency Measures in the U.S. Iron and Steel Industry.

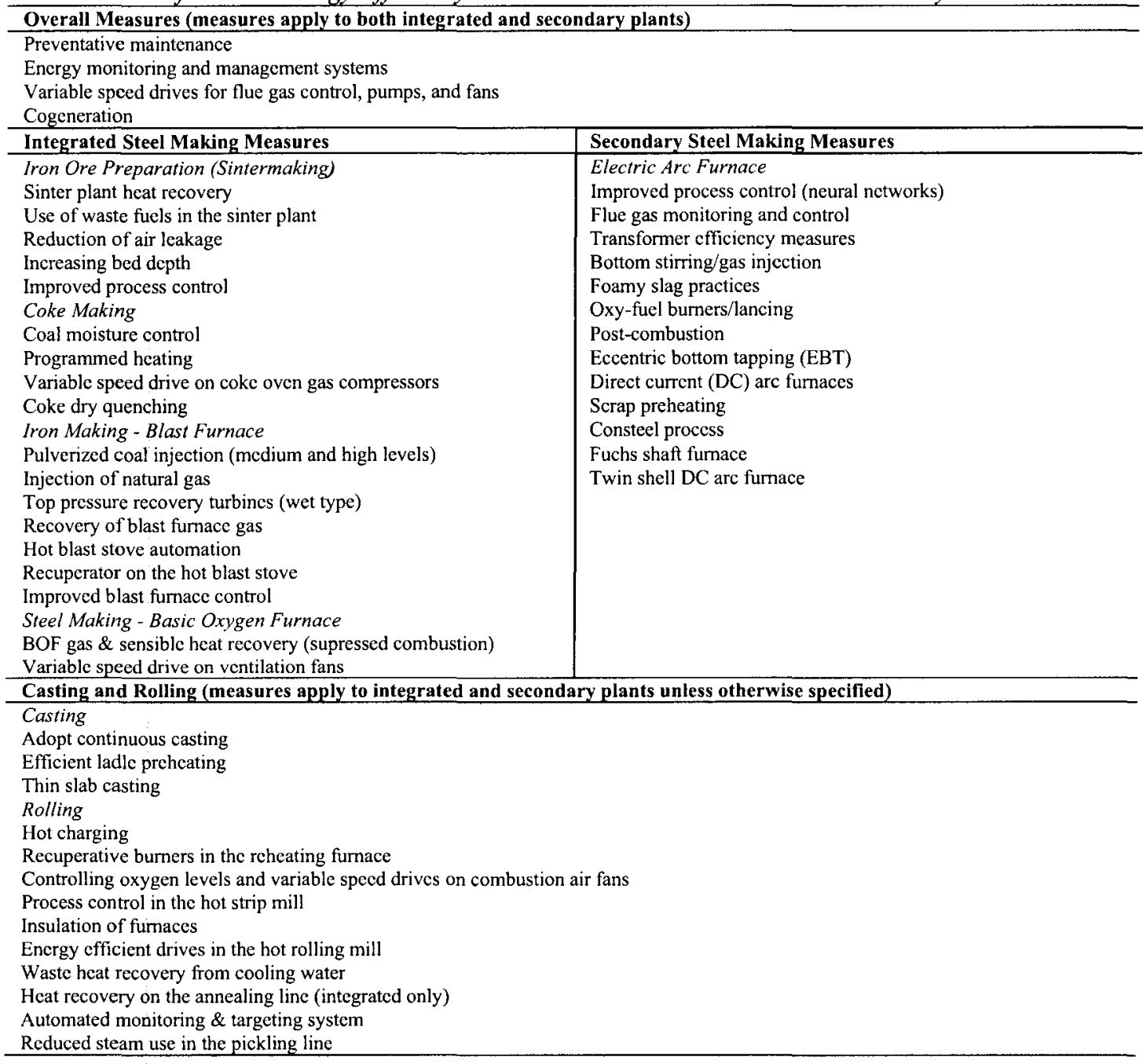


Table 4. Energy Savings, Costs, and Carbon Dioxide Emissions Reductions for Energy-Efficiency Technologies and Measures Applied to Integrated Steel Production in the U.S. in 1994

\begin{tabular}{|c|c|c|c|c|c|c|c|c|}
\hline Option & $\begin{array}{c}\text { Production } \\
\text { (Mtonne) }\end{array}$ & $\begin{array}{c}\text { Fucl Savings } \\
\text { (GJ/tonne } \\
\text { crude stecl) }\end{array}$ & $\begin{array}{c}\text { Electricity } \\
\text { Savings } \\
\text { (GJ/tonne } \\
\text { crude steel) } \\
\end{array}$ & $\begin{array}{c}\text { Primary } \\
\text { Energy } \\
\text { Savings } \\
\text { (GJ/tonne } \\
\text { crude steel) } \\
\end{array}$ & $\begin{array}{c}\text { Annual } \\
\text { Operating } \\
\text { Costs } \\
\text { (US\$/tonne } \\
\text { crude sted) } \\
\end{array}$ & $\begin{array}{c}\text { Retrofit } \\
\text { Capital Cost } \\
\text { (USS/tonne } \\
\text { crude steel) }\end{array}$ & $\begin{array}{c}\text { Carbon } \\
\text { Dioxide } \\
\text { Emissions } \\
\text { Reduction } \\
(\mathrm{kgC} / \mathrm{t}) \\
\end{array}$ & $\begin{array}{c}\text { Share of } \\
\text { Production } \\
\text { Measure } \\
\text { Applied } \\
\text { (percent) } \\
\end{array}$ \\
\hline Iron Ore Preparation (Sinterfing) &  & T.? & (1) & 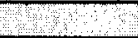 & & (1)? & - & \\
\hline Sinter plant heat recovery & 12.1 & 0.12 & 0.00 & 0.12 & 0.00 & 0.66 & 3.41 & $100 \%$ \\
\hline Reduction of air lcakage & 12.1 & 0.00 & 0.00 & 0.01 & 0.00 & 0.02 & 0.12 & $100 \%$ \\
\hline Increasing bed depth & 12.1 & 0.02 & 0.00 & 0.02 & 0.00 & 0.00 & 0.59 & $100 \%$ \\
\hline Improved process control & 12.1 & 0.01 & 0.00 & 0.01 & 0.00 & 0.03 & 0.30 & $100 \%$ \\
\hline Use of waste fuels in sinter plant & 12.1 & 0.04 & 0.00 & 0.04 & 0.00 & 0.04 & 1.16 & $74 \%$ \\
\hline Coke Making & 1310. & (2) & 4.070 & 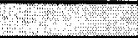 & 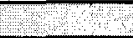 & 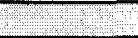 & 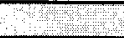 & ton \\
\hline Coal moisture control & 16.6 & 0.09 & 0.00 & 0.09 & 0.00 & 14.69 & 0.55 & $100 \%$ \\
\hline Programmed heating & 16.6 & 0.05 & 0.00 & 0.05 & 0.00 & 0.07 & 0.31 & $100 \%$ \\
\hline $\begin{array}{l}\text { Variable speed drive coke oven gas } \\
\text { compressors }\end{array}$ & 16.6 & 0.00 & 0.00 & 0.00 & 0.00 & 0.09 & 0.01 & $100 \%$ \\
\hline Coke dry quenching & 16.6 & 0.37 & 0.00 & 0.37 & 0.15 & 20.99 & 2.25 & $100 \%$ \\
\hline Iron Making - Blast Furnace 4 &  & $4+3$ & 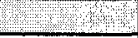 & vis.us & मn, & एक & 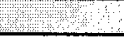 & +3 \\
\hline $\begin{array}{l}\text { Pulverized coal injection to } 130 \\
\mathrm{~kg} / \mathrm{thm}\end{array}$ & 49.4 & 0.69 & 0.00 & 0.69 & -1.78 & 6.24 & 11.42 & $80 \%$ \\
\hline $\begin{array}{l}\text { Pulverized coal injection to } 225 \\
\mathrm{~kg} / \mathrm{thm}\end{array}$ & 49.4 & 0.51 & 0.00 & 0.51 & -0.89 & 4.64 & 8.45 & $30 \%$ \\
\hline Injection of natural gas to $140 \mathrm{~kg} / \mathrm{hm}$ & 49.4 & 0.80 & 0.00 & 0.80 & -1.78 & 4.46 & 13.35 & $20 \%$ \\
\hline $\begin{array}{l}\text { Top pressure recovery turbines (wet } \\
\text { type) }\end{array}$ & 49.4 & 0.00 & 0.10 & 0.30 & 0.00 & 17.84 & 4.29 & $20 \%$ \\
\hline Recovery of blast fumace gas & 49.4 & 0.06 & 0,00 & 0.06 & 0.00 & 0.27 & 0.98 & $60 \%$ \\
\hline Hot blast stove automation & 49.4 & 0.33 & 0.00 & 0.33 & 0.00 & 0.27 & 5.49 & $60 \%$ \\
\hline Recuperator hot blast stove & 49.4 & 0.07 & 0.00 & 0.07 & 0.00 & 1.25 & 1.19 & $100 \%$ \\
\hline $\begin{array}{l}\text { Improved blast fumace control } \\
\text { systems }\end{array}$ & 49.4 & 0.36 & 0.00 & 0.36 & 0.00 & 0.32 & 5.93 & $50 \%$ \\
\hline \multicolumn{2}{|l|}{ Sleelmaking - Basic Oxyget Furnace } & 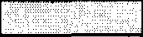 & 3 & 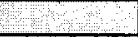 & 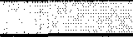 &  & -5 & \\
\hline BOF gas + sensible heat recovery & 55.4 & 0.92 & 0.00 & 0.92 & 0.00 & 22.00 & 12.55 & $100 \%$ \\
\hline $\begin{array}{l}\text { Variable speed drive on ventilation } \\
\text { fans }\end{array}$ & 55.4 & 0.00 & 0.00 & 0.01 & 0.00 & 0.20 & 0.14 & $100 \%$ \\
\hline Integrated Casting ? & +3 & ty? & 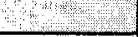 & $4:$ &  & But & 40 & 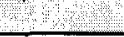 \\
\hline Adopt continuous casting & 49.5 & 0.24 & 0.08 & 0.49 & -5.35 & 11.95 & 36.06 & $9 \%$ \\
\hline Efficient ladle preheating & 49.5 & 0.02 & 0.00 & 0.02 & 0.00 & 0.05 & 0.27 & $84 \%$ \\
\hline Thin slab casting & 49.5 & 3.13 & 0.57 & 4.89 & .31 .33 & 134.25 & 177.60 & $20 \%$ \\
\hline Integrated Hof Rolling & (n) & 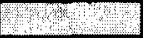 & 10 & (.). & +14. & 40 & 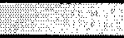 & 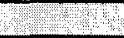 \\
\hline Hot charging & 48.3 & 0.52 & 0.00 & 0.52 & -1.15 & 13.09 & 7.18 & $22 \%$ \\
\hline Process control in hot strip mill & 48.3 & 0.26 & 0.00 & 0.26 & 0.00 & 0.61 & 3.59 & $69 \%$ \\
\hline Recuperative burners & 48.3 & 0.61 & 0.00 & 0.61 & 0.00 & 2.18 & 8.38 & $20 \%$ \\
\hline Insulation of furnaces & 48.3 & 0.14 & 0.00 & 0.14 & 0.00 & 8.73 & 1.91 & $30 \%$ \\
\hline $\begin{array}{l}\text { Controlling oxygen levels and VSDs } \\
\text { on combustion air fans }\end{array}$ & 48.3 & 0.29 & 0.00 & 0.29 & 0.00 & 0.44 & 3.95 & $50 \%$ \\
\hline Energy-efficient drives (rolling mill) & 48.3 & 0.00 & 0.01 & 0.03 & 0.00 & 0.17 & 0.39 & $50 \%$ \\
\hline Waste heat recovery (cooling water) & 48.3 & 0.03 & 0.00 & 0.03 & 0.06 & 0.70 & 0.46 & $69 \%$ \\
\hline \multicolumn{9}{|l|}{$\begin{array}{l}\text { Integrated Cold Rolling and } \\
\text { Frishing. }\end{array}$} \\
\hline Heat recovery on the annealing line & 31.7 & 0.17 & 0,01 & 0.19 & 0.00 & 1.55 & 2.73 & $50 \%$ \\
\hline Reduced steam use (pickling line) & 31.7 & 0.11 & 0.00 & 0.11 & 0.00 & 1.61 & 1.55 & $80 \%$ \\
\hline $\begin{array}{l}\text { Automated monitoring and targeting } \\
\text { system }\end{array}$ & 31.7 & 0.00 & 0.12 & 0.38 & 0.00 & 0.63 & 5.51 & $50 \%$ \\
\hline General : $: 40$ & 4 & +4 & Sut? & (1) & 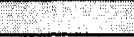 & 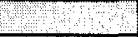 & में & 3 \\
\hline Preventative maintenance & 55.4 & 0.43 & 0.02 & 0.49 & 0.02 & 0.01 & 9.74 & $100 \%$ \\
\hline $\begin{array}{l}\text { Energy monitoring and management } \\
\text { system }\end{array}$ & 55.4 & 0.11 & 0.01 & 0.14 & 0.00 & 0.15 & 2.60 & $100 \%$ \\
\hline Cogeneration & 55.4 & 0.03 & 0.35 & 1.1 & 0.00 & 14.52 & 22.39 & $100 \%$ \\
\hline $\begin{array}{l}\text { Variable speed drive: flue gas control, } \\
\text { pumps, fans }\end{array}$ & 55.4 & 0.00 & 0.02 & 0.06 & 0.00 & 1.30 & 0.40 & $50 \%$ \\
\hline
\end{tabular}


Table 5. Energy Savings, Costs, and Carbon Dioxide Emissions Reductions for Energy-Efficiency Technologies and Measures Applied to Secondary Steel Production in the U.S. in 1994.

\begin{tabular}{|c|c|c|c|c|c|c|c|c|}
\hline Option & $\begin{array}{l}\text { Production } \\
\text { (Mtonne) }\end{array}$ & $\begin{array}{c}\text { Fuel } \\
\text { Savings } \\
\text { (GJ/tonne } \\
\text { crude steel) }\end{array}$ & $\begin{array}{c}\text { Electricity } \\
\text { Savings } \\
\text { (GJ/tonne } \\
\text { crude steel) } \\
\end{array}$ & \begin{tabular}{|c|} 
Primary \\
Energy \\
Savings \\
(GJ/tonne \\
crude steel) \\
\end{tabular} & $\begin{array}{c}\text { Annual } \\
\text { Operating } \\
\text { Costs } \\
\text { (US\$/tonne } \\
\text { crude steel) } \\
\end{array}$ & $\begin{array}{c}\text { Retrofit } \\
\text { Capital } \\
\text { Cost } \\
\text { (US\$/tonne } \\
\text { crude steel) } \\
\end{array}$ & $\begin{array}{c}\text { Carbon } \\
\text { Dioxide } \\
\text { Emissions } \\
\text { Reductions } \\
(\mathrm{kgC} / \mathrm{q}) \\
\end{array}$ & $\begin{array}{c}\text { Share of } \\
\text { Production } \\
\text { Measure } \\
\text { Applied } \\
\text { (percent) } \\
\end{array}$ \\
\hline \multicolumn{9}{|l|}{ Steelmaking Electric Are Fumace } \\
\hline $\begin{array}{l}\text { Improved process control (neural } \\
\text { network) }\end{array}$ & 35.9 & 0.00 & 0.11 & 0.33 & -1.00 & 0.95 & 4.81 & $90 \%$ \\
\hline Fluegas Monitoring and Control & 35.9 & 0.00 & 0.05 & 0.17 & 0.00 & 2.00 & 2.40 & $50 \%$ \\
\hline $\begin{array}{l}\text { Transformer efficiency - UHP } \\
\text { transformers }\end{array}$ & 35.9 & 0.00 & 0.06 & 0.19 & 0.00 & 2.75 & 2.72 & $40 \%$ \\
\hline $\begin{array}{l}\text { Bottom Stirring / Stirring gas } \\
\text { injection }\end{array}$ & 35.9 & 0.00 & 0.07 & 0.22 & -2.00 & 0.60 & 3.20 & $11 \%$ \\
\hline Foamy Slag Practice & 35.9 & 0.00 & 0.07 & 0.20 & -1.80 & 10.00 & 2.88 & $35 \%$ \\
\hline Oxy-fuel burners & 35.9 & 0.00 & 0.14 & 0.44 & -4.00 & 4.80 & 6.41 & $25 \%$ \\
\hline $\begin{array}{l}\text { Eccentric Bottom Tapping (EBT) on } \\
\text { existing furnace }\end{array}$ & 35.9 & 0.00 & 0.05 & 0.17 & 0.00 & 3.20 & 2.40 & $52 \%$ \\
\hline DC-Arc furnace & 35.9 & 0.00 & 0.32 & 1.00 & -2.50 & 3.90 & 14.42 & $5 \%$ \\
\hline $\begin{array}{l}\text { Scrap preheating - Tunnel furnace } \\
\text { (CONSTEEL) }\end{array}$ & 35.9 & 0.00 & 0.22 & 0.66 & -1.90 & 5.00 & 9.61 & $20 \%$ \\
\hline $\begin{array}{l}\text { Scrap preheating, post combustion - } \\
\text { Shaft furnace (FUCHS) }\end{array}$ & 35.9 & -0.70 & 0.43 & 0.63 & -4.00 & 6.00 & 9.62 & $20 \%$ \\
\hline Twin Shell DC w/ scrap preheating & 35.9 & 0.00 & 0.07 & 0.21 & -1.10 & 6.00 & 3.04 & $10 \%$ \\
\hline Secondary Casting & theren & P. & ?.? & 3 & - & & DY? & \\
\hline Efficient ladle preheating & 32.1 & 0.02 & 0,00 & 0.02 & 0.00 & 0.05 & 0.27 & $100 \%$ \\
\hline Thin slab casting & 32.1 & 2.86 & 0.57 & 4.62 & -31.33 & 134,29 & 64.68 & $20 \%$ \\
\hline Secondary Hot Rolling & s.t.p. & Wम & 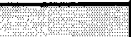 & trat. & का? & ${ }^{2}$ &  & (m) \\
\hline Process control in hot strip mill & 31.3 & 0.26 & 0.00 & 0.26 & 0.00 & 0.61 & 3.59 & $88 \%$ \\
\hline Recuperative burners & 31.3 & 0.61 & 0.00 & 0.61 & 0.00 & 2.18 & 8.38 & $88 \%$ \\
\hline Insulation of furnaces & 31.3 & 0.14 & 0.00 & 0.14 & 0.00 & 8.73 & 1.92 & $30 \%$ \\
\hline $\begin{array}{l}\text { Controlling oxygen levels and VSDs } \\
\text { on combustion air fans }\end{array}$ & 31.3 & 0.29 & 0.00 & 0.29 & 0.00 & 0.44 & 3.95 & $50 \%$ \\
\hline $\begin{array}{l}\text { Energy-efficient drives in the rolling } \\
\text { mill }\end{array}$ & 31.3 & 0.00 & 0.01 & 0.03 & 0.00 & 0.17 & 0.39 & $50 \%$ \\
\hline $\begin{array}{l}\text { Waste heat recovery from cooling } \\
\text { water }\end{array}$ & 31.3 & 0.03 & 0.00 & 0.03 & 0.06 & 0.70 & 0.46 & $88 \%$ \\
\hline General Technologles & 4 & 103 & +4? & (2) & Pि & 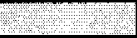 & 40 & \\
\hline Preventative maintenance & 35.9 & 0.09 & 0.05 & 0.24 & 0.02 & 0.01 & 4.09 & $100 \%$ \\
\hline $\begin{array}{l}\text { Energy monitoring \& management } \\
\text { system }\end{array}$ & 35.9 & 0.02 & 0.01 & 0.06 & 0.00 & 0.15 & 1.02 & $100 \%$ \\
\hline
\end{tabular}

Advanced technologies and measures for reducing energy use and carbon dioxide emissions include smelt reduction processes (e.g. COREX, CCF, DIOS, AISI, and HISmelt) for integrated steelmaking, the Contiarc and Comelt processes for secondary steelmaking, and strip casting. These technologies are not currently in commercial use (except the COREX process). The major developments are described in Appendix E.

Fuel and electricity savings for each efficiency measure in Tables 4 and 5 were usually calculated as savings per tonne product (e.g. $0.5 \mathrm{GJ} / \mathrm{t}$ sinter). To convert savings from a per tonne product basis to a per tonne crude steel basis we multiplied the savings by the ratio of throughput (production from a specific process) to total crude steel ${ }^{24}$. Operating and capital costs are also calculated on a crude steel basis according to the same methodology as fuel and electricity savings. Our determination of the share of production to which each measure is applied was based on a variety of information sources on the U.S. iron and steel industry in 1994 and expert judgment. Finally, carbon dioxide emissions reductions for each measure were calculated based on a weighted average carbon dioxide emissions coefficient (tC/GJ) for each process step. We have attempted to account for interactive effects when estimating the potential savings through assessing the possible degree of implementation, as well as interactive effects caused by the order of implementation of technologies. We generally assumed that the most cost-effective technology was implemented first, unless technical reasons determine the order of implementation.

${ }^{24}$ For example, if a measure saved $1 \mathrm{GJ} / \mathrm{t}$ iron, the equivalent savings per tonne of primary crude steel would equal $0.89 \mathrm{GJ} / \mathrm{t}$ crude steel ( 1 * 49.4 Mt iron production/55.4 Mt integrated crude steel production). 


\section{Overall Measures}

Preventative maintenance involves training personnel to be attentive to energy consumption and efficiency. Successful programs have been launched in many industries (Caffal, 1995; Nelson, 1994). Examples of good housekeeping in steel making include timely closing of furnace doors to reduce heat leakage and reduction of material wastes in the shaping steps. We estimate energy savings of $2 \%$ of total energy use, or fuel savings of 0.45 $\mathrm{GJ} / \mathrm{t}$ of product and electricity savings of $0.04 \mathrm{GJ}_{\mathrm{e}} / \mathrm{t}$ of product, based on savings experienced at an integrated steel plant in The Netherlands (Worrell et al., 1993). We assume minimal investment costs for good housekeeping options ( $\$ 0.01 / t)$, although training and in-house information are needed, resulting in increased annual operating costs. Based on good housekeeping projects at Rover (a large car manufacturing plant in the UK), we estimate annual operating costs of about $\$ 11,000$ per plant, or approximately $\$ 0.02 / \mathrm{t}$ crude steel (Caffal, 1995). We apply this measure to all integrated and secondary steel making in the U.S. in 1994.

Energy monitoring and management systems. This measure includes site energy management systems for optimal energy recovery and distribution between various processes and plants. A wide variety of such energy management systems exist (Worrell et al., 1997; Caffal, 1995). Based on experience at the Hoogovens steel mill (The Netherlands) and British Steel (Port Talbot, UK), we estimate energy savings of $0.5 \%$, or fuel savings of 0.12 $\mathrm{GJ} / \mathrm{t}$ of product and electricity savings of $0.01 \mathrm{GJ}_{\mathrm{e}} / \mathrm{t}$ of product, for U.S. integrated sites (Farla et al., 1998; ETSU, 1992). We estimate the costs of such a system to be approximately $\$ 0.15 / \mathrm{t}$ crude steel based on the costs for the system installed at Hoogovens $(\$ 0.8 \mathrm{M})$ (Farla et al., 1998). This measure is applied to $100 \%$ of U.S. steel production facilities.

Cogeneration. All plants and sites that need electricity and heat (i.e. steam) in the steel industry are excellent candidates for cogeneration. Conventional cogeneration uses a steam boiler and steam turbine (back pressure turbine) to generate electricity. Steam systems generally have a low efficiency and high investment costs. Current steam turbine systems use the low-cost waste fuels, which may have been vented before, e.g. Inland Steel and US Steel Gary Works (Hanes, 1999). Modern cogeneration units are gas turbine based, using either a simple cycle system (gas turbine with waste heat recovery boiler), a Cheng cycle or STIG (with steam injection in the gas turbine), or a combined cycle integrating a gas turbine with a steam cycle for larger systems. The latter system can also be used to 're-power' existing steam turbine systems. Gas turbine systems mainly use natural gas. Integrated steel plants produce significant levels of off-gases (coke oven gas, blast furnace gas, and basic oxygen furnace-gas). Specially adapted turbines can burn these low calorific value gases at electrical generation efficiencies of $45 \%$ (low heating value, LHV) but internal compressor loads reduce these efficiencies to 33\% (Mitsubishi, 1993). Mitsubishi Heavy Industries has developed such a turbine and it is now used in several steel plants, e.g. Kawasaki Chiba Works (Japan) (Takano et al., 1989) and Hoogovens (The Netherlands) (Anon., 1997c). These systems are also characterized by low NOx emissions (20 ppm) (Mitsubishi, 1993).

In our advanced cogeneration measure, we assume that steel production facilities that have ready access to coke oven gas (55\% of integrated plants) repower their steam turbine generating systems with a combination off-gas turbine/steam turbine system. Currently, $25 \mathrm{PJ}$ of electricity is cogenerated by the iron and steel industry, $72 \%$ (18 PJ) by steam turbine technology (AISI, 1996; EIA, 1997). Given the low level of steam demand in secondary steel making plants, we assume that most of the cogeneration (90\%) occurs in integrated facilities, which would result in a repowering of $55 \%$ of the electricity steam turbine generation systems $(10 \mathrm{PJ})$ with combined off-gas turbine/steam turbine systems. This measure results in an increase in electricity generation of $11 \mathrm{PJ}$, or $1.1 \mathrm{GJ} / \mathrm{t}$ crude steel primary energy. Investments for the turbine systems are $\$ 1090 / \mathrm{kWe}$ (Anon.,1997c). Total investment costs are estimated at $\$ 800$ million or $\$ 14.5 / \mathrm{t}$ crude steel.

Variable speed drives for flue gas control, pumps, fans. Based on experience in the UK, we assume that electricity savings of $42 \%$ are possible through the use of variable speed drives (VSDs) on pumps and fans (Anon., 1994). We assume that this technology can be applied to $5 \%$ of electricity use in integrated steel making (Worrell et al., 1993), resulting in a savings of $0.04 \mathrm{GJ} / \mathrm{t}$ crude steel. Based on a 3.25 year payback of an installed system in the UK and assuming an electricity price of 3 pence $/ \mathrm{kWh}$ (IEA, 1995), we calculate the costs to be $\$ 1.3 / \mathrm{t}$ product. This equals a payback period of 3.4 years under U.S. 1994 conditions. 


\section{Iron Ore Preparation ${ }^{25}$}

Iron ore is prepared in sinter plants where iron ore fines, coke breeze, water treatment plant sludges, dusts, and limestone (flux) are sintered into an agglomerated material (U.S. DOE, OIT, 1996). In 1994, 12.1 Mt of sinter were produced in the U.S. (AISI, 1996). Fuel consumption for this process $26 \mathrm{PJ}$ and electricity consumption was 2 $\mathrm{PJ}$ resulting in a primary energy intensity of $2.6 \mathrm{GJ} / \mathrm{t}$ sinter.

Sinter plant heat recovery. Heat recovery at the sinter plant is a means for improving the efficiency of sinter making. The recovered heat can be used to preheat the combustion air for the burners and to generate high pressure steam which can be run through electricity turbines. Various systems exist for new sinter plants (e.g. Lurgi EOS process) and existing plants can be retrofit (Stelco, 1993; Farla et al., 1998). In 1994, only 15\% of the blast furnace feed consisted of sinter; the remainder of the feed was composed of pellets, pelletized at the mining site (AISI, 1996). We apply this measure to all exising sinter plants and estimate the fuel savings (steam and coke) associated with production of this $12.2 \mathrm{Mt}$ of sinter to be $0.55 \mathrm{GJ} / \mathrm{t}$ sinter, based on a retrofitted system at Hoogovens in The Netherlands, with increased electricity use of $1.5 \mathrm{kWh} /$ tonne sinter (Rengersen et al., 1995). NOx, SOx and particulate emissions are also reduced with this system. The measure has capital costs of approximately $\$ 3 / \mathrm{t}$ sinter (Farla et al., 1998). We do not estimate costs for new sinter plants since it is unlikely that such plants will be built in the U.S., due to the large investment required. New iron making technologies (discussed below) aim at the use or lump ore or ore fines, instead of using agglomerated ores.

Reduction of air leakage. Reduction of air leakages will reduce power losses for the fans by approximately 3-4 $\mathrm{kWh} / \mathrm{t}$ sinter (Dawson, 1993), and could have a positive effect on the heat recovery equipment. These savings may need small investments for repair of the existing equipment. We estimate these costs at $\$ 0.1 / t$ sinter capacity.

Increasing bed depth. Increasing bed depth in the sinter plant results in lower fuel consumption, improved product quality, and a slight increase in productivity. The savings amount to $0.3 \mathrm{~kg}$ coke/t sinter per $10 \mathrm{~mm}$ bed thickness increase, and an electricity savings of $0.06 \mathrm{kWh} / \mathrm{t}$ sinter (Dawson, 1993). We assume a bed thickness in the US of $550 \mathrm{~mm}$ in 1994, which can be increased to $650 \mathrm{~mm}$. This will result in a fuel savings of $0.09 \mathrm{GJ} / \mathrm{t}$ sinter and an electricity savings of $0.002 \mathrm{GJ} / \mathrm{t}$ sinter. No investment costs are assumed for this measure.

Improved process control. Improved process controls in various systems have resulted in energy savings, and many different control systems have been developed. Based on general experience with industrial control and mangement systems, the savings may be estimated at $2-5 \%$ of energy use (Worrell et al.,1997). We conservatively use a figure of $2 \%$ savings or a primary energy savings $0.05 \mathrm{GJ} / \mathrm{t}$ sinter. Capital costs are assumed to be $\$ 0.15 / \mathrm{t}$ sinter (See also the measure on Energy management and monitoring systems).

Use of waste fuels in the sinter plant can reduce the energy demand in sinter making. The energy demand in sinter making is met by mixing iron ore with breeze from coke making and gas in burners. Sinter making is also used to "scavenge" byproducts such as millscale and iron-containing dusts and sludges. It is possible to use waste oils (especially from cold rolling mills) which are currently landfilled (U.S. DOE, OIT, 1996), however the use will be limited by emission limits due to incomplete combustion. A well-monitored combustion process could reduce the use of gas in the burners (Cores et al.,1996). It is difficult to estimate the savings for this measure, since it depends on the composition and quantity of lubricants and the installed gas clean-up system at the sinter plant. However, based on a survey of European mills, the average sludge production from cold rolling mills is $1 \mathrm{~kg} / \mathrm{t}$ rolled material. The variation can be large, though, ranging from 0.01 to $10 \mathrm{~kg} / \mathrm{t}$ steel. The oil content is less than $10 \%$ and the sludge contains around $45-55 \%$ iron. While this does not represent much energy, it is beneficial to process this sludge in the sinter plant to recover the iron losses. About $50 \%$ of the sludge is recycled in the sinter plant in Europe. Along with the oil recovery sludges, there are also oil, creases, and emulsions produced at a rate of $1.3 \mathrm{~kg} / \mathrm{t}$ rolled steel (Roederer and Gourtsoyannis, 1996). Assuming that the high heating value of these oils is the same as that of heavy fuel oil, total oil production is estimated to be around $1.2 \mathrm{~kg}$ oil $/ \mathrm{t}$ rolled steel (assuming

\footnotetext{
${ }^{25}$ Two energy efficiency measures that we do not include are the use of higher quality iron ores in iron ore preparation and reduction of the basicity of the sinter (Aichinger, 1993). These measure are not considered due to lack of data on current implementation and future potential in the U.S.
} 
$7.5 \%$ in oil recovery sludges and $90 \%$ in oils, creases, and emulsions). We assume a calorific value of $34 \mathrm{MJ} / \mathrm{kg}$, or an energy savings of $41 \mathrm{MJ} / \mathrm{t}$ rolled steel, or $0.18 \mathrm{GJ} / \mathrm{t}$ sinter. (Cores et al., 1996). This is measure is applied to integrated plants with sinter plants on site (allowing for waste recovery), or $74 \%$ of the rolling sludges and oils $(1.68 \mathrm{PJ})$. Bethlehem steel has developed a waste recovery and waste injection system, at a cost of about $\$ 25 \mathrm{M}$ to recycle 200 ktons of various materials (Schriefer, 1997). We estimate the tonnage of waste fuels recycled to be 4,800 tons at an estimated production of $4 \mathrm{Mt}$ rolled steel. With an estiamted sinter production of $3 \mathrm{Mt}$, this results in a cost of $\$ 0.20 / \mathrm{t}$ sinter.

Other measures include the use of higher quality iron ores, low $\mathrm{FeO}$-content, and replacing $\mathrm{SiO}_{2}$ by $\mathrm{MgO}$, reduction of the basicity of the sinter, increasing the bed depth, and the use of coarse coke breeze (Aichinger,1993; Dawson,1993). The implementation of these other measures is not included due to lack of data regarding energy savings and costs.

\section{Coke Making}

Currently there are 50 active coke batteries in the U.S. with a total production in 1994 of $16.6 \mathrm{Mt}$ coke (Hogan and Koelble, 1996b). Coke making consumed $74 \mathrm{PJ}$ of fuel and $2 \mathrm{PJ}$ of electricity, resulting in a primary specific energy consumption of $4.9 \mathrm{GJ} / \mathrm{t}$ (U.S. DOE, OIT, 1996).

Coal moisture control uses the waste heat from the coke oven gas to dry the coal used for coke making. The moisture content of coal varies, but it is generally around $8-9 \%$ for good coking coal (IISI, 1982). Drying reduces the coal moisture content to a constant 3-5\% (Stelco, 1993; Uematsu, 1989) which in turn reduces fuel consumption in the coke oven by approximately $0.3 \mathrm{GJ} / \mathrm{t}$. The coal can be dried using the heat content of the coke oven gas or other waste heat sources. Coal moisture control costs for a plant in Japan were $\$ 21.9 / \mathrm{t}$ of steel (Inuoe, 1995). Based on Japanese coke use data in 1990, we assume approximately $450 \mathrm{~kg}$ coke/t of crude steel, resulting in coal moisture control costs of $\$ 49 / \mathrm{t}$ coke or $\$ 14.7 / \mathrm{t}$ crude steel. We apply this measure to $100 \%$ of U.S. coke production in 1994.

Programmed heating instead of conventional constant heating of the coke ovens ensures optimization of the fuel gas supply to the oven at the various stages of the coking process and reduces the heat content of the coke before charging (IISI, 1982). Use of programmed heat can lead to fuel savings of about $10 \%$ (IISI, 1982), estimated to be $0.17 \mathrm{GJ} / \mathrm{t}$ coke. Small capital costs regarding the computer control system for the coke oven are incurred. We estimate these costs to be $\$ 75 \mathrm{~K}$ per coke battery for a large energy management system (derived from Caffal, 1995 ), which is equivalent to approximately $\$ 0.23 / \mathrm{t}$ coke for the coking capacity of the integrated steel mills (excluding merchant coke producers). This measure is also applied to $100 \%$ of U.S. coke production in 1994.

Variable speed drive coke oven gas compressors can be installed to reduce compression energy. Coke oven gas is generated at low pressures and is pressurized for transport in the internal gas grid. However, the coke oven gas flows vary over time due to the coking reactions. We assume that the compressors are driven with steam turbines, since we lack information on the coke oven gas compressors in the U.S., and that this measure can therefore be applied to all U.S. coke making facilities. Installing a variable speed drive system on a compressor at a coke plant in The Netherlands saved 6-8 MJ/t coke, at an investment of $\$ 0.3 / \mathrm{t}$ coke (Farla et al., 1998).

Coke dry quenching is an alternative to the traditional wet quenching of the coke, and this process reduces dust emissions, improves the working climate, and recovers the sensible heat of the coke. Dry coke quenching is typically implemented as an environmental control technology. Various systems are used in Brazil, Finland, Germany, Japan, and Taiwan (IISI, 1993), but all essentially recover the heat in a vessel where the coke is quenched with an inert gas (nitrogen). The heat is used to produce steam (approximately $400-500 \mathrm{~kg} \mathrm{steam} / \mathrm{t}$ ), equivalent to 800-1200 MJ/t coke (Stelco, 1993; Dungs and Tschirner, 1994). The steam can be used on site or to generate electricity. For new coke plants the costs are estimated to be $\$ 50 / t$ coke, based on the construction costs of a recently built plant in Germany (Nashan, 1992). However, it is very unlikely that new coke plants will be constructed in the U.S., so we use retrofit capital costs in the calculation. Retrofit capital costs depend strongly on the lay-out of the coke plant and can be very high, up to $\$ 70$ to $\$ 90 / \mathrm{GJ}$ saved (Worrell et al., 1993). We assume 
$\$ 70 / t$ coke. Operating and maintenance costs are estimated to increase by $\$ 0.5 / \mathrm{t}$ coke. We apply this measure to all U.S. coke making facilities.

\section{Iron Making - Blast Furnace}

Iron making is the most energy-intensive step in integrated steel making. In 1994 there were 40 blast furnaces in the U.S., producing $49.3 \mathrm{Mt}$ of iron (AISI, 1995). Iron making consumed $676 \mathrm{PJ}$ fuel and 4 PJ electricity, resulting in a primary specific energy consumption of $13.9 \mathrm{GJ} / \mathrm{t}$.

One of the main energy efficiency measures in the iron making stage is the injection of fuels into the blast furnace, especially the injection of pulverized coal (PCI). Pulverized coal injection replaces the use of coke, reducing coke production and hence saving energy consumed in coke making (above) and reducing emissions of coke ovens and associated maintenance costs. Coal injection has increased in recent years due to environmental legislation combined with the high average age of U.S. coke plants. Closing of old coke plants is leading to increased coke imports. In 1994 coke was mainly imported from Japan, China, and Australia (Hogan and Koelble, 1996b).

Increased fuel injection requires energy for oxygen injection, coal, and electricity and equipment to grind the coal. The coal replaces part of the coke that is used to fuel the chemical reactions. Coke is still used as support material in the blast furnace. The maximum fuel injection depends on the geometry of the blast furnace and impact on the iron quality (e.g. sulfur). Coal injection is common practice in many European blast furnaces and is increasing in the U.S. to reduce the amount of coke required. Maximum theoretical coal injection rates are around $280-300 \mathrm{~kg} / \mathrm{t}$ hot metal. In the U.S. the coal injection rate varies. A 1994 survey of seven blast furnaces in the U.S. gave fuel injection rates between 41 and $226 \mathrm{~kg} / \mathrm{t}$ hot metal (Lanzer and Lungen, 1996). The highest injection rates, of 225 $\mathrm{kg} / \mathrm{t}$, have been reached at USX Gary (Schuett et al., 1997). Coke replacement rates vary between $85 \%$ and $100 \%$ (Schuett et al., 1997). We assume that $1 \mathrm{~kg}$ of coke will be replaced by $1.08 \mathrm{~kg}$ of injection fuel, a replacement rate of $92 \%$.

The investments for coal grinding equipment are estimated to be $\$ 50-55 / \mathrm{t}$ coal injected (Farla et al., 1998). O\&M costs show a net decrease due to reduced coke purchase costs and/or reduced maintenance costs of existing coke batteries, which is partly offset by the increased costs of oxygen injection and increased maintenance of the blast furnace and coal grinding equipment. We estimate the reduced operation costs on the basis of 1994 prices of steam coal and coking coal to be $\$ 15 / \mathrm{t}$ (IEA, 1995). This is a low estimate, as cost savings of up to $\$ 33 / \mathrm{t}$ are possible, resulting in a net reduction of $4.6 \%$ of the costs of hot metal production (Oshnock, 1995a).

Pulverized coal injection to $130 \mathrm{~kg} / \mathrm{t}$ hot metal. In this measure, the average coal injection rate is increased from the current average of $2 \mathrm{~kg} / \mathrm{t}$ hot metal (U.S. DOE, OIT, 1996) to $130 \mathrm{~kg} / \mathrm{t}$ hot metal for all blast furnaces. This net increase of $128 \mathrm{~kg} / \mathrm{t}$ hot metal leads to fuel savings of $0.77 \mathrm{GJ} / \mathrm{t}$ hot metal with capital costs of $\$ 7 / \mathrm{t} \mathrm{hot} \mathrm{metal} \mathrm{(Farla}$ et al., 1998). Operation costs will decrease by $\$ 2 / \mathrm{t}$ hot metal (IEA, 1995). ${ }^{26}$ This measure is applied to $80 \%$ of all blast furnaces; injection of natural gas (see below) is applied to the remaining $20 \%$. Injection of pulverized coal may lead to reduced capacity utilization of the blast furnace (Hanes, 1999). Hence, the economic benefits may vary by plant.

Pulverized coal injection to $225 \mathrm{~kg} / \mathrm{t}$ hot metal. In this measure, the injection rate is increased to $225 \mathrm{~kg} / \mathrm{t} \mathrm{hot}$ metal (as reached at USX Gary blast furnace 13) for the large volume blast furnaces only (defined as those with production rates of 2.3-3.6 Mt/year, which is approximately $30 \%$ of total production) (Schuett et al., 1997). This leads to fuel savings of $0.57 \mathrm{GJ} / \mathrm{t}$ hot metal, with an extra investment of $\$ 5.2 / \mathrm{t}$ hot metal and reduced operating costs of $\$ 1 /$ hot metal.

Injection of natural gas. ${ }^{27}$ This measure is only applied to a portion of medium sized furnaces, defined as those with production rates of $1.3-2.3 \mathrm{Mt} / \mathrm{year}$, represent $20 \%$ of total furnaces. Currently, coal is seen as the favorable

\footnotetext{
${ }^{26}$ Costs are calculated as follows: $128 \mathrm{~kg}$ coal $/ \mathrm{t}$ hot metal $=0.128 \mathrm{t} \mathrm{coal} / \mathrm{t}$ hot metal $* \$ 55$ capital costs $=\$ 7 / \mathrm{t}$ hot metal.

${ }^{27}$ The implementation level of this measure will interact with the level of pulverized coal injection. Following further research, we may revise both this and the pulverized coal injection measure to reflect an increased emphasis on the use of natural gas
} 
injection fuel because of its low price. Injection of natural gas is an alternative. Maximum injection rates are lower than for coal (Oshnock, 1995b). Replacement rates for natural gas vary between 0.9 and $1.15 \mathrm{~kg}$ natural gas $/ \mathrm{kg}$ coke (Oshnock, 1995b). Natural gas injection tests by the Gas Research Institute show a maximum injection rate of $130-150 \mathrm{~kg} / \mathrm{t}$ hot metal, with estimated costs savings of \$4-5/t hot metal (Anonymous, 1995). Assuming a replacement rate of $1 \mathrm{~kg}$ natural gas $/ \mathrm{kg}$ coke, savings from replacing $140 \mathrm{~kg}$ of coke are estimated to be $0.9 \mathrm{GJ} / \mathrm{t}$ hot metal. We assume that operating costs will decrease similar to that seen in the lower PCI injection measure $(\$ 2 / \mathrm{t}$ hot metal).

Top pressure recovery turbines (wet type) are used to recover the pressure in the furnace. ${ }^{28}$ Although the pressure difference is low, the large gas volumes make the recovery economically feasible. The pressure difference is used to produce $15-40 \mathrm{kWh} / \mathrm{t}$ hot metal (Stelco, 1993). Turbines are installed at blast furnaces worldwide, especially in areas where electricity prices are relatively high (e.g. Western Europe, Japan). The standard turbine has a wet gas cleanup system. The top gas pressure in the U.S. is generally too low for economic power recovery (I\&SM, 1997). A few large blast furnaces (representing $20 \%$ of production) have sufficiently high pressure. Future upgrades of blast furnaces might lead to increasing top pressures to improve productivity. We assume a power recovery of $30 \mathrm{kWh} / \mathrm{t}$ hot metal in the U.S., with typical investments of about $\$ 20 / \mathrm{t}$ hot metal (Inoue, 1995) for $20 \%$ of the 1994 U.S. blast furnace capacity.

Recovery of blast furnace gas during charging of the blast furnace is designed to recover the $1.5 \%$ of gas that is lost during charging. A recovery system has been developed and installed by Hoogovens in The Netherlands. The savings are estimated to be $66 \mathrm{MJ} / \mathrm{t}$ hot metal at a cost of $\$ 0.3 / \mathrm{t}$ hot metal (Farla et al., 1998). We assume that such systems can be installed in $60 \%$ of U.S. blast furnace capacity based on an estimate of the number of bell-type charging mechanisms in the U.S.

Hot blast stove automation can help to reduce the energy consumption of the stoves, increase the reliability of the operation, increase stove life-time, and optimize gas mix (Beentjes et al., 1989; Derycke et al., 1990; Kowalski et al., 1990). The energy savings of such systems are estimated to be between 5\% (Beentjes et al., 1989) and 12 to 17\% (Derycke et al., 1990). Based on the high fuel consumption of hot blast stoves in the U.S. (U.S. DOE, OIT, 1996) we assume savings of $370 \mathrm{MJ} / \mathrm{t}$ hot metal (Derycke et al., 1990). The installation of a hot blast stove automation system at Sidmar, Gent (Belgium) had a payback of two months (Derycke et al., 1990). We assume an investment cost of $\$ 0.3 / \mathrm{t}$ hot metal, to be implemented in all small blast furnaces, or $60 \%$ of the total U.S. blast furnace capacity (equivalent to $30.3 \mathrm{Mt}$ in 1994). We assume that all blast furnaces with capacities over $4500 \mathrm{t}$ hot metal/day have already installed automatic control systems.

Recuperator hot blast stove. Hot blast stoves are used to heat the combustion air of the blast furnace. The exit temperature of the hot blast stove flue gases is approximately $250^{\circ} \mathrm{C}$. The heat can be recovered to preheat the combustion air of the stoves. Various recovery systems have been developed and implemented (Stelco, 1993). Fuel savings vary between 80 and $85 \mathrm{MJ} / \mathrm{t}$ hot metal (Farla et al., 1998; Stelco, 1993). We assume savings of $80 \mathrm{MJ} / \mathrm{t}$ hot metal. The costs of recuperation systems are high and depend strongly on the size of the stoves (i.e. the blast furnace). We estimate the costs to be $\$ 18-20 /$ GJ saved (Farla et al., 1998), equivalent to $\$ 1.4 / \mathrm{t}$ hot metal. An efficient hot blast stove can run without the need for natural gas. We apply this measure to $100 \%$ of 1994 U.S. blast furnaces.

Improved blast furnace control systems have been developed in Japan and Europe that provide improved control over systems currently used in Canada (Stelco, 1993) and presumably in the U.S. A successful control system has

over coal due to $\mathrm{CO} 2$ concerns. At this time, we do not have adequate data on actual levels of natural gas injection. Other fuels can also be injected, but we have not included any due to lack of data. Injection of plastic wastes has been tested at Stahlwerke Bremen in Germany at rates of $30 \mathrm{~kg} / \mathrm{t}$ hot metal (Janz and Weiss, 1996). Chlorine content (due to PVC) may lead to dioxin formation, making efficient flue gas control equipment necessary.

${ }^{28}$ Top pressure recovery turbines (dry type) use a dry gas clean up system which raises the turbine inlet temperature, increasing the power recovery by about $25-30 \%$ (Stelco, 1993). However, the system is more expensive, estimated at 28 US\$/t hot metal (Inoue, 1995). Due to the high costs, we assume that this system will not be implemented on existing blast furnaces in the U.S. in the near term. 
been installed at Rautaruukki Steel Works in Raahe, Finland, reducing total fuel use to $440-450 \mathrm{~kg} / \mathrm{t}$ hot metal (Stelco, 1993), and increasing productivity and flexibility (Pisila et al,, 1995). British Steel has developed an expert system for blast furnace control (Fitzgerald, 1992). We estimate the savings of improved blast furnace control strategies at half of the savings reached at Rautaruukki, i.e. $0.4 \mathrm{GJ} / \mathrm{t}$ hot metal (Pisila et al., 1995), with the other half attributed to charge material upgrading. Capital costs are estimated to be $\$ 0.5 \mathrm{M}$ per blast furnace. With 40 blast furnaces and a combined capacity of $55.5 \mathrm{Mt}$ this is equivalent to $\$ 0.36 / \mathrm{t}$ hot metal (Hogan and Koelble, 1996a). No large changes in operating costs are expected. We apply this measure to $50 \%$ of 1994 U.S. blast furnaces.

\section{Iron Making - Alternatives}

Direct reduced iron (DRI), hot briquetted iron (HBI,) and iron carbide are all alternative iron making processes (McAloon, 1994). Because of the small production quantities (in the reference year 1994) we do not discuss energy efficiency measures in the alternative iron making processes separately. In 1994 only one producer (Georgetown Steel) produced $480 \mathrm{kt}$ DRI (Midrex, 1995), using a gas-based Midrex process built in 1971. The energy consumption of a state-of-the-art Midrex-unit is 10 to $11 \mathrm{GJ} / \mathrm{t}$ iron and $110 \mathrm{kWh} / \mathrm{t}$ (Midrex, 1993). DRI is produced through the reduction of iron ore pellets below the melting point of the iron. DRI is mainly used as a high quality iron input in electric arc furnace (EAF) plants. The U.S. steel industry also imports DRI from countries in Latin America. New DRI plants are being constructed in Alabama (a mothballed plant built originally in 1975 in Scotland) and in Louisiana (a new Midrex Megamod module) and other plants have been announced. A new alternative iron production process, the iron carbide process, has been pioneered by Nucor which has one plant operating in Trinidad and another plant scheduled to be built in Texas. The growing production by EAF plants in the U.S., high scrap prices, and the need for high quality inputs due to the expansion of EAF producers in the flat steel market will increase the future demand for alternative iron inputs.

Steel Making - Basic Oxygen Furnace (BOF)

In basic oxygen furnace (BOF) steelmaking a charge of molten iron and scrap steel along with some other additives (manganese and fluxes) is heated and refined to produce crude steel. BOF crude steel production in 1994 was 55.3 Mt with fuel and electricity consumption of $19 \mathrm{PJ}$ and $6 \mathrm{PJ}$, respectively. Primary energy intensity for this process step in our base year (1994) was $0.7 \mathrm{GJ} / \mathrm{t}$.

BOF gas and sensible heat recovery (supressed combustion) is the single most energy-saving process improvement in this process step, making the BOF process a net energy producer. By reducing the amount of air entering over the convertor, the $\mathrm{CO}$ is not converted to $\mathrm{CO}_{2}$. The sensible heat of the off-gas is first recovered in a waste heat boiler, generating high pressure steam. The gas is cleaned and recovered. The total savings vary between 535 and $916 \mathrm{MJ} / \mathrm{t}$ steel, depending on the way the steam is recovered (Stelco, 1993). Supressed combustion reduces dust emissions and since the metal content of the dust is high, about $50 \%$ of the dust can be recycled in the sinter plant (Stelco, 1993). The costs will depend on the need for extra gas holders. Supressed combustion is very common in integrated steel plants in Europe and Japan. In the U.S. no BOF gas seems to be recovered (U.S. DOE, OIT, 1996; Hanes, 1999), so we apply this measure to $100 \%$ of U.S. BOF steelmaking. We assume an energy recovery rate of $916 \mathrm{MJ} / \mathrm{t}$ crude steel (Stelco, 1993), with estimated capital costs of $22 \$ / \mathrm{t}$ crude steel, based on plants in Japan (Inoue, 1995) and The Netherlands (Worrell et al., 1993).

Variable speed drive on ventilation fans. The BOF process is basically a batch process. The volumes of flue gases vary widely over time, making variable speed drives an option. Large fans are used in the BOF plant to control air quality. At Hoogovens the use of variable speed drives has been shown to save power (Worrell et al., 1993) in the BOF, reducing the power demand by approximately $20 \%$, or $0.9 \mathrm{kWh} / \mathrm{t}$ crude steel (Farla et al., 1998). With total costs of $\$ 1 \mathrm{M}(1988)$ the investment costs are $\$ 0.2 / \mathrm{t}$ crude steel (Farla et al., 1998). We assume that such variable speed drives could be used in all U.S. BOF steelmaking facilities.

Secondary Steel Making - Electric Arc Furnace (EAF)

Electric arc furnace or secondary steelmaking involves the production of steel from scrap metal which is melted and refined using electricity in an electric arc furnace (U.S. DOE, OIT, 1996). Electric arc furnaces are on average 
smaller capacity compared to blast furnace/BOF capacity and use less energy. In 1994 there were 122 secondary steel mills with 226 electric arc furnaces. EAF steel production in 1994 was $35.9 \mathrm{Mt}$ and energy consumption for the furnaces was $6 \mathrm{PJ}$ fuel and $62 \mathrm{PJ}$ of electricity, reflecting a primary energy intensity of $5.5 \mathrm{GJ} / \mathrm{t}$.

Improved process control (neural networks) can help to reduce electricity consumption beyond that achieved through classical control systems. For example, neural networks or "fuzzy logic" systems analyze data and emulate the best controller. For EAFs, the first "fuzzy logic" control systems have been developed using current, power factor and power use to control the electrodes in the bath (Staib and Bliss, 1995). The average power savings are estimated to be up to $8 \%$ (or $38 \mathrm{kWh} / \mathrm{t}$ ), with an average increase in productivity of $9-12 \%$ and reduced electrode consumption of $25 \%$ (Staib and Bliss, 1995). The actual savings depend on the scrap used and the furnace operation. Furnace maintenance costs are reduced as well. We assume an average efficiency improvement of 30 $\mathrm{kWh} / \mathrm{t}$ (or $0.1 \mathrm{GJ} / \mathrm{t}$ ). In 1994, advanced control systems were installed at 16 furnaces in the U.S. (Kimmerling, 1997), with a total capacity of $5.8 \mathrm{Mt}$ (equivalent to $9 \%$ of the U.S. EAF capacity in 1994). The capital and commissioning costs are estimated to be $\$ 250,000$ per furnace, with annual costs savings at roughly $\$ 1 / \mathrm{t}$ (Kimmerling, 1997). Since the average capacity of EAF plants was $260 \mathrm{kt} / \mathrm{year}$ in 1994, we estimate the capital costs to be $\$ 0.95 / t$. The measure is assumed to be applicable for $90 \%$ of the U.S. EAF capacity.

Flue gas monitoring and control using variable speed drives can reduce the energy use for the flue gas fans, reducing the heat losses in the flue gas (Stockmeyer et al., 1990; Walli,1991; Worrell et al.,1997). The flue gas flow varies over time, which makes the use of variable speed drives possible. Flue gas VSDs have been installed in various countries (e.g. Germany, UK). The electricity savings are estimated to be $15 \mathrm{kWh} / \mathrm{t}$ (Stockmeyer et al.,1990), with a payback period of 2 to 3 years (Walli,1991; Worrell et al.,1997). We estimate the capital investments to be $\$ 2 / \mathrm{t}$, and apply this measure to all furnaces with a size of $100 \mathrm{t}$ or larger, equivalent to $50 \%$ of the U.S. EAF capacity.

Ultra high power transformers. Transformer losses can be as high as $7 \%$ of the electrical inputs (CMP, 1992). The losses will depend mainly on the sizing and age of the transformer. When replacing the transformer it is possible to convert furnace operation to ultra high power, increasing productivity, as well as reducing energy losses. Ultra high power furnaces are those with a transformer capacity of over $700 \mathrm{kVA} / \mathrm{t}$ heat size (IISI, 1983). The savings are estimated at $1 \mathrm{kWh} / \mathrm{t}$ per MW power increase. The weighted 1994 average transformer capacity is estimated to be $480 \mathrm{kVA} / \mathrm{t}$ heat size for all non-ultra high power (UHP) furnaces. In $199438 \%$ of EAF capacity can be classified as UHP furnaces. Many EAF operators have installed new transformers and electric systems to increase the power of the furnaces, e.g. Co-Steel (Raritan, NJ), SMI (Sequin, TX), Bayou Steel (Laplace, LA) (Ninneman, 1997). UHP operation might lead to heat fluxes, and increased refractory wear, making cooling of the furnace panels necessary (Teoh, 1990). This results in heat losses partially offsetting the power savings. The increased power can be reached by installing new transformers or paralleling existing transformers. The replacement of a 93 MVA transformer at Co-Steel (Raritan, NJ) with one rated at 120-144 MVA in 1997 was included in a project totally costing $\$ 6.2 \mathrm{M}$ (Ninneman,1997). This is equivalent to approximately $8.3 \$ / \mathrm{t}$ steel produced. This is a high cost estimate as the total project costs included other equipment as well. We assume that all transformers for medium to large furnaces over 15 years old can be replaced by more efficient equipment. This is equivalent to approximately 115 furnaces with a capacity of $32.2 \mathrm{Mts}(40 \%$ of the total EAF capacity). We assume that the losses can be reduced to $4 \%$, saving approximately $14 \mathrm{kWh} / \mathrm{t}$. Transformers are assumed to have a lifetime of 15 years. The total energy savings are estimated to be $17 \mathrm{kWh} / \mathrm{t},(14 \mathrm{kWh}$ due to transformer replacement and $3 \mathrm{kWh}$ for upgrading to UHP).

Bottom stirring/stirring gas injection is done by injecting an inert gas (e.g. argon) in the bottom of the EAF, which increases the heat transfer in the melt and the interaction between slag and metal (leading to an increased liquid metal yield of $0.5 \%$ ) (Schade, 1991). This increased stirring in the bath can lead to electricity savings of 11 to $22 \mathrm{kWh} / \mathrm{t}$, with annual net production cost reduction of $\$ 0.5$ to $1.0 / \mathrm{t}$ accounting for increased labor and argon costs, based on tests at Lukens Steel Co. in 1990 (Schade, 1991). Increased liquid steel yield increases the net cost savings to $\$ 0.9-2.3 / t$ (Jones, 1993). Furnaces with oxygen injection are sufficiently turbulent, reducing the need for inert gas stirring (see below). We assume power savings of $20 \mathrm{kWh} / \mathrm{t}$ and cost savings of $\$ 1.5 / \mathrm{t}$. No data are available on the current application rate in U.S. EAFs. We assume potential application in $11 \%$ of the $1994 \mathrm{EAF}$ 
capacity (i.e. small AC furnaces without oxygen injection). The capital costs for retrofitting existing furnaces are estimated to be \$0.6/t (1987) (Riley and Sharma, 1987) for increased refractory costs and installing tuyeres. The annual costs for inert gas purchases are estimated to be $\$ 1.1 / \mathrm{t}$ (Riley and Sharma, 1987). The productivity increase (excluding saved energy costs, including saved electrode costs, labor and alloys) is estimated to be $\$ 3.1 / \mathrm{t}$ (Riley and Sharma, 1987). The lifetime of the tuyeres is limited to 100-200 heats (Riley and Sharma, 1987), or approximately 6 months.

Foamy slag practice helps to reduce the heat losses through radiation from the melt by covering the arc and melt surface with foamy slag. Foamy slag can be obtained by injecting carbon (granular coal) and oxygen, or lancing of oxygen only. Foamy slag practice seems to be common with a large number of operators in the U.S., so the potential savings are limited. However, not all operators have implemented the practice well. We will assume that all medium to large furnaces without oxygen injection can still implement this technology. Approximately $30-40 \%$ of the 1994 capacity (Jones, 1998) could still implement foamy slag practice, or improve the application. The net energy savings (accounting for energy use for oxygen production) are estimated at 5-7 kWh/tonne steel (derived from Adolph et al., 1990). Based on the costs of installing oxygen lances the investments are estimated at approximately 10\$/tonne capacity (Jones, 1997b). Foamy slag practice may also increase productivity through reduced tap-to-tap times, which is equivalent to a $\mathrm{n}$ estimated cost saving of $1.8 \$ /$ tonne steel (derived from Adolph et al.,1990).

Oxy-fuel burners/lancing can be installed in EAFs to reduce electricity consumption by substituting electricity with fuels, increase heat transfer and reduce heat losses (foamy slag, see above). Typical savings range from 2.5 to 4.4 kWh per Nm3 oxygen injected (IISI, 1982; CMP, 1987; Haissig, 1994; Stockmeyer et al.,1990), with common injection rates of $18 \mathrm{Nm} 3 / \mathrm{t}$ (IISI,1982). The injection rate can be increased to $26 \mathrm{~m} 3 / \mathrm{t}$ with increased fuel injection. Natural gas injection is $10 \mathrm{scf} / \mathrm{kWh}$, or $0.3 \mathrm{~m} 3 / \mathrm{kWh}$, (CMP, 1992), with typical savings of 20-40 kWh/t (Jones, 1996). Approximately $29 \%$ of the 1994 capacity (or $16 \mathrm{Mt}$ in medium to large furnaces) has no oxy-fuel burners installed (I\&SM, 1997b). These furnaces have an average power consumption of $502 \mathrm{kWh} / \mathrm{t}$. We assume implementation of oxy-fuel burners in $25 \%$ of the existing EAF capacity, with net energy savings of approximately $40 \mathrm{kWh} / \mathrm{t}$. Modification investment costs depend on the furnace size. With an average EAF size of 110 tons, the investments are estimated to be approximately $\$ 4.8 / \mathrm{t}$ (Jones, 1996a). The improved heat distribution leads to reduced tap-to-tap times of about 6\% (CMP, 1995), leading to estimated annual cost savings of $\$ 4.0 / \mathrm{t}$ (CMP, 1987). Oxygen injection also reduces the nitrogen content of the steel, leading to improved product quality (Douglas, 1993). We estimate a lifetime of 10 years for this measure.

Post-combustion of the flue gases of the EAF helps to optimize the benefits of oxygen and fuel injection. The CO can be further oxidized to $\mathrm{CO} 2$, while using the combustion heat of the gases to heat the steel in the EAF ladle (through the fourth hole or in the freeboard) or to preheat the scrap. Electricity savings depend on the amount of oxygen injected, and are estimated to be $2.8 \mathrm{kWh} / \mathrm{m}^{3}$ of post-combustion oxygen injected (Kleimt and Koehle, 1997). Electricity savings can amount to 50 to $80 \mathrm{kWh} / \mathrm{t}$ (Gregory et al., 1996; Jones, 1997a). In the US, Cascade Steel (OR) has installed a post-combustion system, saving approximately $64 \mathrm{kWh} / \mathrm{t}$ (Gregory et al., 1996). We will assume that post combustion will be used for scrap preheating (see below).

Eccentric bottom tapping (EBT). Eccentric bottom tapping is applied in most modern furnaces, leading to slagfree tapping, shorter tap-to-tap times (increased productivity), reduced refractory consumption, reduced electrode consumption ( 0.1 to $0.3 \mathrm{~kg} / \mathrm{t}$ ) and improved ladle life. EBT helps to reduce energy losses and to improved emissions control. The energy savings are estimated to be $15 \mathrm{kWh} / \mathrm{t}(0.05 \mathrm{GJ} / \mathrm{t})(\mathrm{CMP}, 1992)$. Reconstructing an existing EAF furnace at Ipsco, Regina (Saskatchewan, Canada) cost \$2.2 M (Ninneman, 1997). The furnace has an annual production capacity of $688 \mathrm{kt}$, estimating the retrofit costs at $\$ 3.2 / \mathrm{t}$ capacity. It is assumed that all new furnaces have EBT (Ritt, 1996). We assume that EBT can be installed in all medium to large capacity EAF built before 1986 (29.5 Mts), as the technology was introduced commercially around 1983 (Teoh, 1990), or equivalent to $52 \%$ of the production.

DC arc furnaces use direct current (DC) instead of conventional alternating current (AC). In a DC furnace one single electrode is used, and the bottom of the vessel serves as the anode, resulting in improved heat distribution in 
the furnace. This reduces the power consumption. Another major advantage of DC furnaces is the reduced tap-totap time and electrode consumption (down to 1.2-1.6 kg/t steel) (Macauley and Smailer, 1997; Mueller, 1997;), increased refractory life, and improved stability (Jones,1997b; Stelco,1993). DC technology is applicable to large furnaces (80-130 theat size), and small furnaces are expected to remain AC systems. Larger DC-furnaces (using two electrodes) are being investigated. The disadvantage of DC-systems are the up to $10-35 \%$ higher capital costs (Jones, 1997b). Currently, the maximum current is restricted due to the use of one electrode, but UHP DC systems are under development (Palacios and Arana, 1995). In the US, Charter Steel, Florida Steel, Gallatin Steel, North Star, and Nucor (Hickman, Berkeley, Norfolk) are using DC furnaces. The 1994 average power consumption of furnaces over 100 ton heat size is estimated at $473 \mathrm{kWh} / \mathrm{t}(430 \mathrm{kWh} / \mathrm{ton})$. The Nucor-plant (Hickman) achieves a consumption of $368 \mathrm{kWh} / \mathrm{t}, 36 \mathrm{Nm} 3$ oxygen and $0.5-1.8 \mathrm{~kg}$ electrode (Mueller, 1997). The net energy savings are estimated at $90 \mathrm{kWh} / \mathrm{t}$ (accounting for oxygen production at $0.4 \mathrm{kWh} / \mathrm{Nm} 3$ (Hendriks, 1994)). Compared to new $\mathrm{AC}$ furnaces the savings are limited to $10-20 \mathrm{kWh} /$ tonne (Jones, 1998). Based on a cost-estimate for a 100 ton furnace the net extra investments compared to an AC furnace are estimated to be $\$ 2.7 \mathrm{M}$, or $\$ 3.9 / \mathrm{t}$ capacity (1991) (CMP, 1991). Whereas the cost savings are estimated at $\$ 2$ to $\$ 6 /$ ton (CMP, 1991). This includes electrode cost savings, that are approximately $\$ 2 /$ ton steel (CMP, 1992). We assume annual cost savings (excluding energy costs) of $\$ 2.5 /$ t. Introducing DC furnaces competes with oxygen lancing, fuel injection, post combustion, and eccentric bottom tapping. We assume a market penetration of $15 \%$ of capacity in the US, of which two-thirds is assumed to use as a twin shell to preheat scrap (see below).

Scrap preheating is a technology that can reduce the power consumption of EAFs through using the waste heat of the furnace to preheat the scrap charge. Old (bucket) preheating systems had various problems, e.g. emissions, high handling costs, and a relatively low heat recovery rate. Modern systems have reduced these problems, and are highly efficient. The energy savings depend on the preheat temperature of the scrap. Various systems have been developed and are in use at various sites in the U.S. and Europe, i.e. Consteel tunnel-type preheater, Fuchs Finger Shaft, and Fuchs Twin Shaft. Twin shell furnaces (see below) can also be used as scrap preheating systems. All systems can be applied to new constructions, and also to retrofit existing plants.

The Consteel process consists of a conveyor belt with the scrap going through a tunnel, down to the EAF through a "hot heel". Various U.S. plants have installed a Consteel process, i.e. Florida Steel (now AmeriSteel, Charlotte, NC) New Jersey Steel (Sayreville, NJ) and Nucor (Darlington, SC), and one plant in Japan. The installation at New Jersey Steel is a retrofit of an existing furnace (Lahita, 1995). Besides energy savings, the Consteel-process results in an productivity increase of 33\% (Jones, 1997a), reduced electrode consumption of $40 \%$ (Jones, 1997a) and reduced dust emissions (Herin and Busbee, 1996). Electricity use can be decreased to approximately 370-390 $\mathrm{kWh} / \mathrm{t}$ (Herin and Busbee, 1996) without supplementary fuel injection in retrofit situation, while consumption as low as $340-360 \mathrm{kWh} / \mathrm{t}$ have been achieved (Jones, 1997c) in new plants. We estimate the electricity savings to be $60 \mathrm{kWh} / \mathrm{t}$ for retrofit. The extra investments are estimated to be $\$ 2 \mathrm{M}(1989)$ for a capacity of $400-500,000$ ton per year (Bosley and Klesser, 1991), resulting in specific investments of approximately $\$ 4.4$ to $\$ 5.5 /$ t. The annual costs savings due increased productivity, reduced electrode costs and increased yield are estimated to be $\$ 1.9 / \mathrm{t}$ (Bosley and Klesser, 1991).

The FUCHS shaft furnace consists of a vertical shaft that channels the offgases to preheat the scrap. The scrap can be fed continuously (4 plants installed world wide) or through a so-called system of 'fingers' (15 plants installed worldwide) (VAI, 1997). The optimal recovery system is the 'double shaft' furnace ( 3 plants installed worldwide), which can only be applied for new construction. The Fuchs-systems make almost $100 \%$ scrap preheating possible, leading to potential energy savings of 100-120 kWh/t (Hofer, 1997). The energy savings depend on the scrap used, and the degree of post-combustion (oxygen levels). In the U.S. Fuchs systems have been installed at North Star (single shaft (1996), Kingman, AZ), North Star-BHP (double shaft (1996), Delta, OH), Birmingham Steel (finger shaft (1997), Memphis, TN). Two other Finger shaft processes have been ordered by Chapparel (TX) and North Star (Youngstown, $\mathrm{OH}$ ). Carbon monoxide and oxygen concentrations should be well controlled to reduce the danger of explosions, as happened at North Star-BHP. The scrap preheating systems lead to reduced electrode consumption, yield improvement of 0.25-2\% (CMP, 1997; VAI, 1997), up to $20 \%$ productivity increase (VAI, 1997) and 25\% reduced flue gas dust emissions (reducing hazardous waste handling costs) (CMP, 1997). A special system has been developed for retrofitting existing furnaces called the Fuchs Optimized Retrofit Shaft, with a relatively short shaft. Retrofit costs are estimated at $\$ 6 / t$ (Hofer, 1997) for an existing $100 \mathrm{t}$ furnace. 
Using post-combustion the energy consumption is estimated at $340-350 \mathrm{kWh} / \mathrm{t}$ (Jones, 1997d) and $0.7 \mathrm{GJ}$ fuel injection (Hofer, 1996). The production costs savings amount up to $\$ 4.5 / \mathrm{t}$ (excluding saved electricity costs) (Hofer, 1997).

Scrap preheating competes with oxy-fuel injection and post combustion, as these options are basically integrated in most scrap preheating systems. All furnaces over $70 \mathrm{t}$ capacity could be retrofitted cost-effectively (Hofer, 1996), or $74 \%$ of the 1994 U.S. capacity (using on average $470 \mathrm{kWh} / \mathrm{t}$ in 1994), leading to net power savings of approximately $120 \mathrm{kWh} / \mathrm{t}$ and increased fuel consumption of $0.7 \mathrm{GJ} / \mathrm{t}$.

Twin shell furnace. The Twin shell concept comprises two EAF-vessels with a common arc and power supply system. The system increases the productivity by reducing the tap-to-tap time to approximately 45 to 50 minutes (Heinrich, 1995, Ninneman, 1997), and reducing energy costs through reduced heat losses. Also, the hot flue gases of one shell can be used to preheat the second shell. A twin shell AC plant is estimated to use $393 \mathrm{kWh} / \mathrm{t}$ compared to $412 \mathrm{kWh} / \mathrm{t}$, saving $19 \mathrm{kWh} / \mathrm{t}$ (Macauley and Smailer,1997) compared to current state-of-the-art single vessel plants for a $100 \%$ scrap feed. The twin shell DC plant can save even more, $80 \mathrm{kWh} / \mathrm{t}$ compared to the 1994 average large scale AC furnace. The twin-shell concept can only be applied in the construction of a new plant. New plants in the U.S. using the Twin Shell concept are Gallatin Steel, Nucor, Steel Dynamics, and Tuscaloosa Steel, and the resulting energy use varies for each of these plants. The EAF at Gallatin steel has two AC furnaces, and consumes approximately $450 \mathrm{kWh} / \mathrm{t}$ (Jones, 1997b). DC furnaces can be used as well, reducing the power consumption further (see above). The Twin Shell concept competes with the scrap preheating processes discussed above. Twin shells seem to be an appropriate process for mini mills with capacities over $1 \mathrm{Mt}$ per year. Very little cost data exists on the Twin Shell (Jones, 1997b). The capital cost lay-out is expected to be a little more (with estimated payback in the U.S. of 2 years), while the production costs are expected to be $6 \%$ lower than that of a single shell (Jones, 1997b). We will assume extra investments of $\$ 4-6 / t$ (over those of a new single shell furnace, based on the investments at Nucor, Berkeley County, SC), and production cost reduction of $\$ 1.1 / \mathrm{t}$ (derived from (CMP, 1987), excluding energy cost savings). We assume application of the DC twin shell concept to $10 \%$ of the 1994 production capacity.

\section{Casting}

Once crude steel is produced it is cast into different shapes (billets, blooms, slabs, or ingots). Molten steel is poured into a tundish and then released into a mold of one or more strands. A majority of steel in the U.S. is continuously cast which reduces the need for several intermediate process steps. In 1994 we estimate that casting energy use was 17 PJ fuel and 15 PJ of electricity resulting in a primary energy intensity of $0.7 \mathrm{GJ} / \mathrm{t}$ (U.S. DOE, OIT, 1996).

Adopt continuous casting. In the reference year 1994, 9.6 Mt of crude steel were cast in ingots. The ingots have to be reheated in soaking pits and then rolled in roughing mills to produce slabs. Continuous casting replaces these processes by casting slabs directly with a thickness of about 3 inches, or by casting blooms and billets. Continuous casting reduces the energy needs for the soaking pits, and even more importantly reduces material losses by $6 \%$ (continuous casting material losses are estimated to be $2 \%$ ). Most industrialized countries continuously cast close to $100 \%$ of the steel produced. We assume that $98 \%$ continuous casting is possible in the U.S. steel industry, allowing for the production of heavy plate and other products via the ingot-route. The energy savings amount to $2.86 \mathrm{GJ} / \mathrm{t}$ steel cast (Stelco, 1993; U.S. DOE, OIT, 1996). Hogan (1992) estimates the costs savings due to reduced equipment, handling and material losses to be $\$ 31 / \mathrm{t}$. Based on the investment costs of a new bloom caster at British Steel Scunthorpe Works (capacity of $1.25 \mathrm{Mt} / \mathrm{year}$ ) we assume typical investment costs of $\$ 69 / \mathrm{t}$ (Anon., 1996). One integrated plant in the U.S. (Acme) has replaced an ingot caster by a thin slab caster (see below).

Efficient ladle preheating. The ladle of the caster (and the BOF vessel) is preheated with gas burners. Heat losses can occur through lack of lids and through radiation. The losses can be reduced by installing temperature controls (Caddet, 1989), installing hoods, by using recuperative burners (Caddet, 1987), use of oxygen burners (Gitman, 1998), or by efficient ladle management (reducing the need for preheating). Oxygen burners for ladle preheating are used by many steel companies in the U.S. already (Gitman, 1998), but use can be expanded considerably. No data are available on the actual energy use for preheating ladles in the U.S. steel industry. Therefore, we assume typical fuel use of approximately $0.04 \mathrm{GJ} / \mathrm{t}$ crude steel (Worrell et al., 1993). Efficient preheating will reduce 
energy use by $50 \%$ or $0.02 \mathrm{GJ} / \mathrm{t}$ crude steel, with an estimated payback time of 1.1 year (taking into account savings on ladle handling), or $\$ 0.06 / \mathrm{t}$ product, assuming a gas price of $\$ 2.8 / \mathrm{GJ}$ (IEA, 1995).

Thin slab casting is a new technology integrating casting and hot rolling in one process. Pioneered in the U.S. by Nucor at the Crawfordsville and Hickmann plants, various plants are operating, under construction, or ordered worldwide. Originally designed for small scale process-lines, the first integrated plants constructed (Acme, U.S.; Posco, Korea) or announced the construction of thin slab casters (Germany, Netherlands, Spain) with capacities up to $1.5 \mathrm{Mt}$ /year (Worrell and Moore, 1997). Currently, four suppliers (Germany (2), Austria and Italy) supply this technology. We base our description on the CSP-process developed by SMS (Germany) as it represents most of the capacity installed worldwide. Energy savings are estimated to be $4.9 \mathrm{GJ} / \mathrm{t}$ crude steel (primary energy). The energy consumption of a CSP-plant is $94 \mathrm{MJ}$ fuel per ton for the reheating furnace and electricity use of $43 \mathrm{kWh} / \mathrm{t}$ (Flemming, 1995). The investments for a large scale plant are estimated to vary between $\$ 110 / \mathrm{t}$ and $\$ 180 / \mathrm{t}$ product (Anon, 1997a; Anon., 1997b, Schorsch, 1996). We assume therefore an investment cost of $\$ 134 / \mathrm{t}$ crude steel, with estimated operation cost savings of between $\$ 25 / \mathrm{t}$ and $\$ 46 / \mathrm{t}$ product (derived from Ritt, 1997 and Hogan, 1992 , Schorsch, 1996). We therefore assume an operation cost savings of $\$ 31 / \mathrm{t}$ crude steel. The potential capacity of thin slab casting is estimated to be $20 \%$ of U.S. integrated production and $64 \%$ of secondary steel. ${ }^{29}$

\section{Hot Rolling ${ }^{30}$}

After casting, the shaped products are further rolled to produce sheet, strip, plate, and other structural products (U.S. DOE, OIT, 1996). In 1994, 79.6 Mt of steel was hot rolled with an estimated energy requirement of $259 \mathrm{PJ}$ fuel and $56 \mathrm{PJ}$ of electricity, resulting in a primary energy intensity of $5.4 \mathrm{GJ} / \mathrm{t}$. This energy intensity is relatively high compared to other countries and additional data is required to improve this estimate (U.S. DOE, OIT, 1996).

Hot charging is used to charge slabs at an elevated temperature into the reheating furnace of the hot rolling mill. The slabs can be charged at various temperatures. Higher charging temperatures will save more energy. The implementation of the technique depends on the lay-out of the plant, and the distance between the caster and the hot rolling mill. In some plants the caster and reheating furnace are "next door" making hot charging less costly (e.g. LTV in Cleveland and Usines Gustav Boel, Belgium). Handling and transport of the slabs (i.e. a so-called 'hot connection') is required if there is more distance between the caster and the rolling mill (Worrell et al., 1993). Hot charging not only saves energy, but also improves material quality, reduces material losses, improves productivity (by up to 6\%), and may reduce slab stocking (Ritt,1996). Care should be taken to descale the slab before charging in the reheating furnace (Caddet, 1990a). The measure competes with thin slab casting (because in thin slab casting the slab is coupled through a reheating furnace to the rolling stands) and direct rolling. A few plants in the U.S. now hot charge a portion of the production, e.g. LTV (Cleveland), USS (Fairfield), Bethlehem (Burns Harbor), and Geneva Steel, although generally only a small percentage of the slab production (10-15\%) is hot charged (Ritt, 1996). We assume that $60 \%$ of cold rolled products (36\% of the slabs) can ultimately be "hot charged", depending on the lay-out of the plants. A plant-by-plant analysis is required to determine the actual potential. Assuming a charging temperature of $700^{\circ} \mathrm{C}$, the savings may be up to $0.6 \mathrm{GJ} / \mathrm{t}$ "hot charged" steel based on experiences at Bethlehem Steel at Burns Harbor (Ritt, 1996). Additional annual costs savings amount up to $\$ 1.15 / \mathrm{t}$ "hot charged". Investment costs will strongly depend on lay-out and are estimated to be $\$ 15 / \mathrm{t}$ hot rolled steel based on experience at LTV (Wakelin, 1997).

\footnotetext{
${ }^{29}$ Estimate for the potential of thin slab casting in integrated mills is estimated to be $60 \%$ of integrated hot strip and sheet production in 1994 or $11 \mathrm{Mt}$ (AISI, 1996). Estimated potential for secondary mills is based on implementation in slabs in minimills not currently continuously cast. These estimates will need to be refined in the future.

${ }^{30}$ An additional measure is efficient power use in the rolling mill, which can reduce the power demand of the hot rolling mill. Current hot strip mill power use in U.S. is estimated to be $220 \mathrm{kWh} / \mathrm{t}(0.8 \mathrm{GJ} / \mathrm{t})$ (U.S. DOE, OIT, 1996). A modern hot strip mill has a power consumption of about $105 \mathrm{kWh} / \mathrm{t}(0.4 \mathrm{GJ} / \mathrm{t})$ (Worrell et al., 1993). Thus, installation of a modern hot strip mill could represent a savings of up to $115 \mathrm{kWh} / \mathrm{t}(0.4 \mathrm{GJ} / \mathrm{t})$. One component in these mills is motors which are used for the rolling as well as in quench pumps. The quench pumps in a hot rolling mill are estimated to use $2.5 \mathrm{kWh} / \mathrm{t}$ (Anon., 1994), on which savings of $42-76 \%$ are feasible through the application of variable speed drives and installing control equipment. This system required an investment equivalent to $0.24 \$ / \mathrm{t}$ product saving $1.9 \mathrm{kWh} / \mathrm{t}$ hot rolled steel $(7 \mathrm{MJe} / \mathrm{t})$. Reduced maintenance costs amount to $0.02 \$ / t$ product (Anon., 1994). This measure needs further quantification before it can be included in the analysis.
} 
Direct rolling is a variation on hot charging and thin slab casting. The standard slab is rolled directly in the hot strip mill, saving handling and energy costs. The energy savings are estimated to be roughly $50 \%$ of the energy costs of standard cold charging (Parodi, 1993). However, in existing integrated plants this option may be difficult to implement, as the rolling stands need to be located directly next to the continuous caster, leading to high retrofit costs. In the U.S., the caster and rolling mill are often not located next to each other. We therefore assume that direct rolling will not be implemented in the U.S., due to competition of hot charging (see above) or the construction of a new thin slab caster (see above).

Thin slab casting is the casting of thin slabs, which are reheated before rolling (see above).

Process control in hot strip mill saves energy and increases productivity and quality of the rolled steel products (Heesen and Burggraaf, 1991; Schriefer, 1996; Vergote, 1996). Although direct energy savings may be limited, the indirect energy savings may be substantial due to reduced rejection of product, improved productivity, and reduced down-time. Based on a system installed at Sidmar (Belgium) the share of rejects was reduced from $1.5 \%$ to $0.2 \%$ and down-time was reduced from more than $50 \%$ of the time to $6 \%$. The costs of rolling were reduced from $\$ 7 / \mathrm{t}$ to $\$ 4.7 /$ t (Vergote, 1996). Similar systems have been installed in mills in many countries. We estimate the energy savings based on the reduced rejection rate and improved productivity to be $9 \%$ of fuel use. We assume this to be equivalent to $0.3 \mathrm{GJ} / \mathrm{t}$ product. The investment costs for the Sidmar plant were estimated to be $\$ 2 \mathrm{M}$ for a hot strip mill with a capacity of $2.8 \mathrm{Mt}$ (Serjeantson, 1987), equivalent to $\$ 0.7 / \mathrm{t}$ product. This measure will be applicable to all slabs that are not cast in a thin-slab caster or sold, i.e. $69 \%$ of the total steel production. The lifetime of process control equipment is estimated at 10 years.

Recuperative burners in the reheating furnace can reduce energy consumption. Industry-wide average savings for the metals industry are estimated to be up to $30 \%$ (Worrell et al., 1997). Energy use in a reheating furnace will depend on production factors (e.g. stock, steel type), operational factors (e.g. scheduling), and design features. Therefore, in practice energy consumption can vary widely between 0.6 and $3.0 \mathrm{GJ} / \mathrm{t}$ (Flanagan, 1993), with the low figures due to hot charging (see above). Based on a survey of 151 furnaces (representing $20 \%$ of Western world steel production) in Japan, Australia, UK and Canada, it was found that $18 \%$ of the furnaces had no heat recovery and $75 \%$ had separate heat recovery (Flanagan, 1993). As no specific U.S. data were available, we assume a similar distribution for the U.S. Installing recuperative or regenerative burners may require substantial changes in the furnace construction and may have high investment costs. New designs have typically low NOx emissions, despite higher flame temperatures. We assume installing regenerative burners in $20 \%$ of the furnaces used in hot rolling mills, saving approximately $25 \%$ on fuel in these (mostly small) furnaces, based on experiences in the UK (Flanagan, 1993), or roughly estimated at $0.7 \mathrm{GJ} / \mathrm{t}$ product. The investments for a $12 \mathrm{t} /$ hour furnace were approximately $\$ 2-3 / \mathrm{t}$. We assume $\$ 2.5 / \mathrm{t}$ product. The burners are expected to have a lifetime of approximately 10 years.

Insulation of furnaces using ceramic low-thermal mass insulation materials (LTM) can reduce the heat losses through the walls further than conventional insulation materials. A survey of steel reheating furnaces in the steel industry in four countries (not including the U.S.) showed that approximately $30 \%$ of the furnaces had ceramic fiber linings (Flanagan, 1993). We assume a similar figure for the U.S. steel industry. For a continuous furnace, the savings of implementing ceramic fiber lining are estimated to be 2-5\% (Flanagan, 1993). We assume savings of $0.16 \mathrm{GJ} / \mathrm{t}$ product. We assume that $30 \%$ of the furnace capacity can be equipped with ceramic lining during maintenance and reconstruction (assuming an approximate life-time of 30 years) in the period until 2005. Although we did not find recent cost data, we assume relative large investments of approximately $\$ 10 / t$ product, derived from de Beer et al. (1994). The lifetime is estimated at 10 years.

Controlling oxygen levels and variable speed drives on combustion air fans on the reheating furnace helps to control the oxygen level, and hence optimize the combustion in the furnace, especially as the load of the furnace may vary over time. The savings depend on the load factor of the furnace and control strategies applied. Two cases from the UK steel industry demonstrate the variety. Implementing a variable speed drive combustion fan on a walking beam furnace at Cardiff Rod Mill (UK) reduced the fuel consumption by $48 \%$ with a payback period of 16 months (1985 UK conditions) (Caddet, 1994). Another example (without installing variable speed drives) is a walking beam furnace for reheating billets, saving approximately $2 \%$ on fuel use, with a payback of one year (1990 
UK conditions) (Flanagan, 1993). We conservatively assume savings of $10 \%$ (after previous measures have been introduced), equivalent to $0.33 \mathrm{GJ} / \mathrm{t}$ product, at an investment of $0.5 \$ / \mathrm{t}$ product. As no data is available on the current penetration of VSDs in reheating furnaces, we assume that this measure can be implemented in half of the furnaces, with a lifetime of approximately 10 years.

Energy efficient drives in the hot rolling mill can replace the currently used conventional $\mathrm{AC}$ drives. The efficiency of large $\mathrm{AC}$ drives $(>200 \mathrm{kWe}$ ) is estimated to be $91-97 \%$ (Worrell and Moore, 1997). High efficiency motors can save approximately $1-2 \%$ of the electricity consumption (de Almeida and Fonsesca, 1997). Assuming an electricity demand of $200 \mathrm{kWh} / \mathrm{t}$ rolled steel, the electricity savings are estimated to be $4 \mathrm{kWh} / \mathrm{t}$, or $0.01 \mathrm{GJ} / \mathrm{t}$ product. Replacement costs are estimated to be $\$ 5 / \mathrm{kW}$ (the extra costs compared to that of an ordinary drive) (de Almeida and Fonsesca, 1997), equivalent to $\$ 0.05 / \mathrm{kWh}$-saved, or $\$ 0.2 / \mathrm{t}$ rolled steel. Large motors have generally a lifetime of 20 years (de Almeida and Fonsesca, 1997). According to Rosenberg (1997) the average penetration of efficient motors in all industrial applications is between 6 and $8 \%$. We assume that $50 \%$ of the motors will be replaced at the above mentioned costs.

Waste heat recovery from cooling water. Waste heat can be recovered from the cooling water of the hot strip mill. When ejected, the rolled steel is cooled by spraying water at a temperature of $80^{\circ} \mathrm{C}$. An absorption heat pump (or heat transformer) has been installed at Hoogovens (The Netherlands) to generate low pressure steam (1.7-3.5 bar, $130{ }^{\circ} \mathrm{C}$ ), which is delivered to the grid on the site. Fuel savings are estimated to be $0.04 \mathrm{GJ} / \mathrm{t}$ product, with an increased electricity consumption of $0.15 \mathrm{kWh} / \mathrm{t}$ (Farla et al.,1997). Investment costs are $42 \mathrm{Dfl} / \mathrm{GJ}$-saved equivalent to $\$ 0.8 / \mathrm{t}$ product (Worrell et al.,1993), with increased O\&M costs estimated at $\$ 0.07 / \mathrm{t}$ product. The heat transformer could be applied with all quench water in the hot rolling mills, e.g. $69 \%$ of the total production. The life time is estimated to be 15 years.

Cold Rolling and Finishing $\underline{31}$

Steel that has been hot rolled may be cold rolled and further finished to make a product thinner and smoother. In $1994,31.7 \mathrm{Mt}$ (35\%) of product was cold rolled, all in integrated mills. Based on fuel consumption of $43 \mathrm{PJ}$ and electricity consumption of $15 \mathrm{PJ}$, the primary energy intensity was $2.8 \mathrm{GJ} / \mathrm{t}$.

Heat recovery on the annealing line can be done through steam generation using the waste heat, or by installing regenerative or recuperative burners in the annealing furnace (Meunier and Cambier, 1993). We aggregate the various energy saving opportunities in one measure, as the total energy consumption in the annealing stage is limited. Energy use for batch annealing is estimated at $1.0 \mathrm{GJ} / \mathrm{t}$ fuel and $25 \mathrm{kWh} / \mathrm{t}$, and for continuous annealing $0.8 \mathrm{GJ} / \mathrm{t}$ and $45 \mathrm{kWh} / \mathrm{t}$ (IISI, 1982). Energy use can be reduced by up to $40 \%$ (Meunier and Cambier, 1993), by implementing heat recovery (using regenerative burners), improved insulation, process management equipment, as well as variable speed drives. We estimate the savings at $0.3 \mathrm{GJ}$ fuel $/ \mathrm{t}$ and $3 \mathrm{kWh} / \mathrm{t}$. All cold rolled steel is assumed to be treated in the annealing furnace, i.e. $30.9 \mathrm{Mt}$ (1994). The total potential energy savings are estimated at $9 \mathrm{PJ}$. The investment costs are estimated at $\$ 2.7 / \mathrm{t}$, based on practices at Hoogovens (The Netherlands).

Reduced steam use in the pickling line. In the pickling line heat escapes through evaporation from the hydrochloric acid bath. The bath is normally heated to temperatures of $95^{\circ} \mathrm{C}$ (IISI, 1982). The IISI (1982) reports that steam use can be reduced by $5 \mathrm{~kg} / \mathrm{t}$, with an assumed steam use of $30 \mathrm{~kg} / \mathrm{t}$, by installing a system of lids and floating balls on top of the bath. This is equivalent to savings of $17 \%$. For the U.S. steel industry we estimate the savings (including boiler losses) to be $0.19 \mathrm{GJ} / \mathrm{t}$. At a production of $32 \mathrm{Mt}$ cold rolled product, the total fuel savings are estimated to be $6 \mathrm{PJ}$. No investment cost data were available for this study. We estimate the costs on the basis of a conservative estimate by de Beer et al. (1994) at $\$ 2.8 / \mathrm{t}$.

Automated monitoring and targeting system. Installing an automated monitoring and targeting system at a cold strip mill can reduce the power demand of the mill, as well as reducing effluents. A system installed at British Steel at Brinsworth Strip Mills, reduced the energy demand of the cold rolling mill by approximately $15-20 \%$,

\footnotetext{
${ }^{31}$ One measure in cold rolling is continuous annealing, which will reduce the heat losses of the batch furnaces but demands relative high investment costs. We do not assume implementation of this measure as an energy efficiency measure.
} 
depending on the load factor (Caddet, 1990b). The savings are estimated to be $60 \mathrm{kWh} / \mathrm{t}$ assuming an average electricity consumption of $360 \mathrm{kWh} / \mathrm{t}$ (U.S. DOE, OIT, 1996). We assume the implementation of a similar system, at installation costs of $\$ 1.1 / \mathrm{t}$ product $(\$ 0.63 / \mathrm{t}$ crude steel) (Caddet, 1990b), for half of the cold strip mills in the U.S. steel industry, or $17 \%$ of the total steel production. 


\section{Energy Efficiency and Carbon Dioxide Emissions Reduction Potential for Steelmaking in the U.S. Energy Conservation Supply Curves}

Supply curves are a common tool in economics. In the 1970s, energy conservation supply curves were developed by energy analysts as a means of ranking energy conservation investments alongside investments in energy supply in order to assess the least cost approach to meeting energy service needs (Meier et al., 1983). Conservation supply curves rank energy efficiency measures by their "cost of conserved energy" (CCE), which accounts for both the costs associated with implementing and maintaining a particular technology or measure and the energy savings associated with that option over its lifetime. The CCE of a particular option is calculated as:

$\mathrm{CCE}=\frac{\text { Annualized Investment }+ \text { Annual Change in O\&M Costs }}{\text { Annual Energy Savings }}$

The annualized investment is calculated as: Capital Cost $\mathrm{x}$

$$
\frac{d}{\left(1-(1+d)^{-n}\right)}
$$

where $d$ is the discount rate and $n$ is the lifetime of the conservation measure. CCEs are calculated for each measure that can be applied in a certain sector or subsector (e.g. steelmaking) and then ranked in order of increasing CCE (Koomey et al., 1991). Once all options have been properly ranked, a conservation supply curve can be constructed. Defining "cost-effective" involves choosing a discount rate that reflects the desired perspective (e.g. customer, society). Then all measures that fall below a certain energy price, such as the average price of energy for the sector, can be defined as cost-effective. ${ }^{32}$

The CCEs are plotted in ascending order to create a conservation supply curve. This curve is a snapshot of the total annualized cost of investment for all of the efficiency measures being considered at that point in time. The width of each option or measure (plotted on the $\mathrm{x}$-axis) represents the annual energy saved by that option. The height (plotted on the y-axis) shows the option's CCE.

The advantage of using a conservation supply curve is that it provides a clear, easy-to-understand framework for summarizing complex information about energy efficiency technologies, their costs, and the potential for energy savings. The curve can avoid double counting of energy savings by accounting for interactions between measures, is independent of prices, and also provides a framework to compare the costs of efficiency with the costs of energy supply technologies.

This conservation supply curve approach also has certain limitations. In particular, the potential energy savings for a particular sector are dependent on the measures that are listed and/or analyzed at a particular point in time. There may be additional energy efficiency measures or technologies that do not get included in an analysis, so savings may be underestimated. The costs of efficiency improvements (initial investment costs plus operation and maintenance costs) do not include all the transaction costs for acquiring all the appropriate information needed to evaluate and choose an investment and there may be additional investment barriers as well that are not accounted for in the analysis (de Beer et al., 1996; Krause et al., 1995).

Many analysts use internal rate of return (IRR) to rate the cost effectiveness of various investments, which is the value of the discount rate to make the net benefits stream equal to the initial investment. A key difference between CCE and IRR is that with an IRR the fuel price for the analysis period is included in the calculation (since energy savings are quantified on a dollar basis), and therefore has a direct effect on the evaluation of a measure. With the CCE calculation changes in fuel prices will not change the CCE of a measure but will change the number of measures that are considered cost effective.

\footnotetext{
${ }^{32}$ For examples of conservation supply curves in the buildings, transportation, and industrial sectors, see Meier et al., 1983; Ross, 1987; Ledbetter and Ross, 1989; Difiglio et al., 1990; EPRI, 1990; Ross, 1990; Block et al., 1993; Interlaboratory Working Group, 1997; Koomey et al., 1991; Krause et al., 1995; Rosenfeld et al., 1991; DeBeer et al., 1996; National Academy of Sciences, 1992; and Worrell, 1994.
} 
For our analysis, we used a 30\% real discount rate, reflecting the steel industry's capital constraints and preference for short payback periods and high internal rates of return. We use an industry average weighted fuel cost in our calculation based on energy data provided by the American Iron and Steel Institute, and cost data from EIA (U.S. DOE, EIA, 1997). We include a weighted fuel cost separate for integrated or for secondary steel making and we use the source price of electricity.

We also note that several efficiency measures provide environmental benefits in addition to energy and cost savings. For example, coke dry quenching reduces dust and particulate emissions associated with the wet quenching process. The use of coal injection in the blast furnaces reduces coke demand and coke-related NOx, SOx, and particulate emissions. While we believe that including quantified estimates of such other benefits would increase the number of cost-effective efficiency options, we have not included such estimates in this current work. This is a subject, however, that merits continued research.

\section{Energy Conservation Supply Curve for U.S. Integrated Steelmaking}

We identified cost-effective energy savings of $236 \mathrm{PJ}$ and carbon dioxide emissions reductions of $5.0 \mathrm{MtC}$ for integrated steelmaking in 1994 which represents $13 \%$ of total U.S. steelmaking energy use and $15 \%$ of total carbon dioxide emissions. Figure 8 ranks the integrated steelmaking measures in a conservation supply curve; the costeffective measures are those which fall below the average weighted energy supply cost for 1994, and are therefore cost effective at 1994 energy prices using a discount rate of $30 \%$. Some of the largest cost-effective energy savings appear possible with such measures as preventative maintenance, coal injection into the blast furnace, and improvements in monitoring and control systems for the blast furnace and rolling mills. Table 6 provides a list of the measures ranked by their cost of conserved energy, internal rate of return, and their simple payback periods.

Figure 8. Energy Conservation Supply Curve for Integrated Steelmaking.

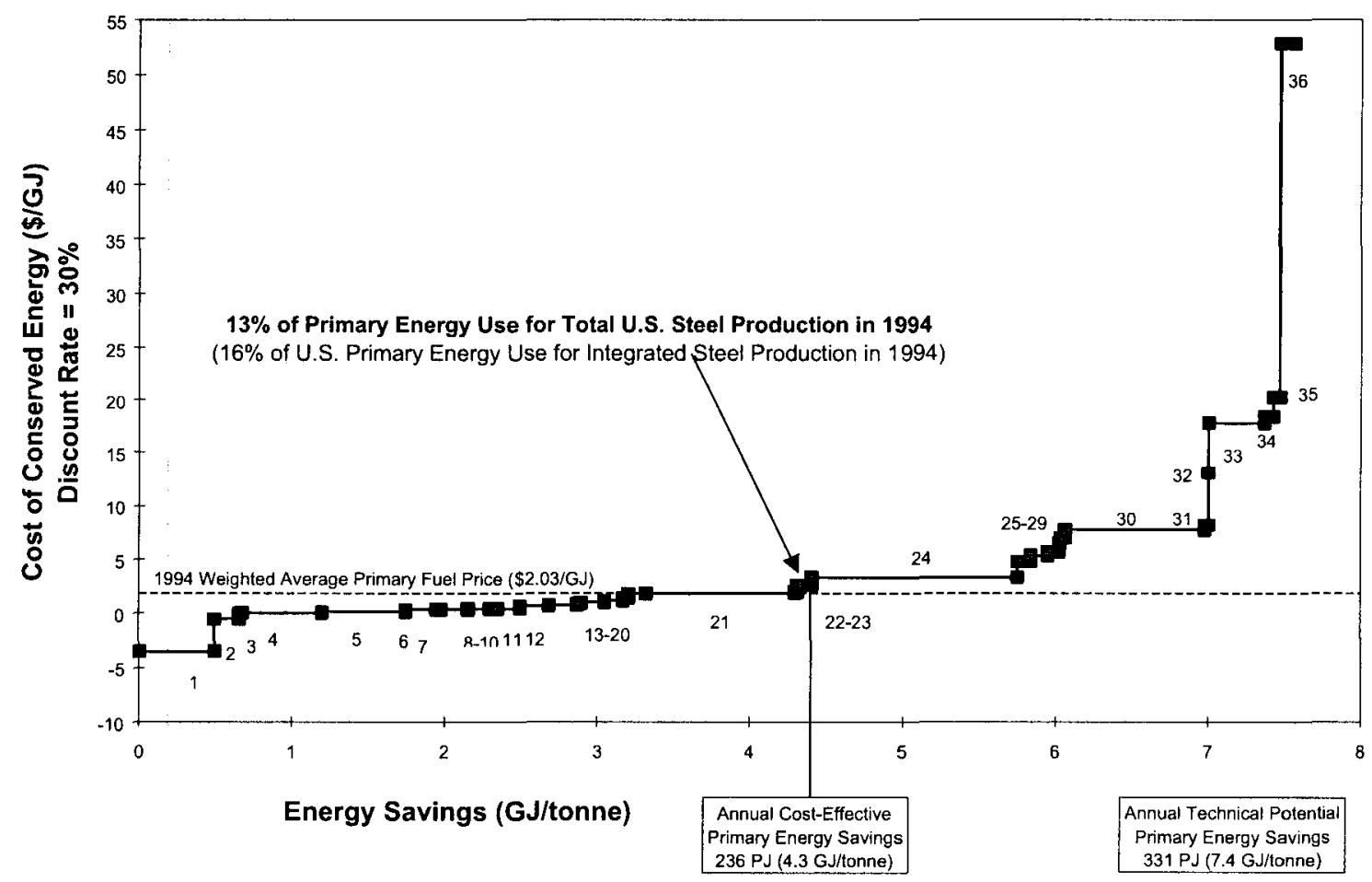


Table 6. Cost of Conserved Energy for Selected Measures in Integrated Steelmaking

\begin{tabular}{|c|c|c|c|c|c|c|}
\hline & \multirow[t]{2}{*}{ Integrated Steelmaking Efficiency Measure } & $\begin{array}{l}\text { Primary } \\
\text { CCE }\end{array}$ & $\begin{array}{c}\text { Primary Energy } \\
\text { Savings }\end{array}$ & $\begin{array}{c}\text { Cumulative } \\
\text { Primary Energy } \\
\text { Savings }\end{array}$ & $\begin{array}{l}\text { Internal } \\
\text { Rate of } \\
\text { Return }\end{array}$ & $\begin{array}{c}\text { Simple Payback } \\
\text { Time }\end{array}$ \\
\hline & & $(\$ / G J)$ & (GJ/tonnc) & (GJ/tonne) & $(\%)$ & (Years) \\
\hline 1 & Adopt continuous casting & -3.52 & 0.50 & 0.5 & $53 \%$ & 1.9 \\
\hline 2 & Injection of natural gas to $140 \mathrm{~kg} / \mathrm{thm}$ & -0.55 & 0.16 & 0.66 & $76 \%$ & 1.3 \\
\hline 3 & Increasing bed depth & 0.00 & 0.02 & 0.68 & $>500 \%$ & 0.0 \\
\hline 4 & Preventative maintenance & 0.04 & 0.52 & 1.20 & $>500 \%$ & 0.0 \\
\hline 5 & Pulverized coal injection to $130 \mathrm{~kg} / \mathrm{thm}$ & 0.14 & 0.55 & 1.75 & $51 \%$ & 2.0 \\
\hline 6 & Hot blast stove automation & 0.33 & 0.20 & 1.94 & $248 \%$ & 0.4 \\
\hline 7 & Use of waste fuels in the sinter plant & 0.35 & 0.03 & 1.97 & $186 \%$ & 0.5 \\
\hline 8 & Improved blast furnace control systems & 0.37 & 0.18 & 2.15 & $224 \%$ & 0.4 \\
\hline 9 & Energy monitoring and management system & 0.43 & 0.14 & 2.30 & $192 \%$ & 0.5 \\
\hline 10 & Programmed heating - coke plant & 0.44 & 0.05 & 2.35 & $149 \%$ & 0.7 \\
\hline 11 & $\begin{array}{l}\text { Controlling oxygen levels and VSDs on combustion } \\
\text { air fans }\end{array}$ & 0.46 & 0.14 & 2.49 & $133 \%$ & 0.8 \\
\hline 12 & Automated monitoring and targeting system & 0.68 & 0.19 & 2.68 & $120 \%$ & 0.8 \\
\hline 13 & Process control in hot strip mill & 0.75 & 0.18 & 2.86 & $86 \%$ & 1.2 \\
\hline 14 & Reduction of air lcakages - sintermaking & 0.83 & 0.01 & 2.87 & $78 \%$ & 1.3 \\
\hline 15 & Efficient ladle preheating & 0.87 & 0.01 & 2.88 & $75 \%$ & 1.3 \\
\hline 16 & Improved process control-sinter plant & 0.94 & 0.01 & 2.89 & $69 \%$ & 1.4 \\
\hline 17 & Pulverized coal injection to $225 \mathrm{~kg} / \mathrm{thm}$ & 1.00 & 0.15 & 3.05 & $41 \%$ & 2.4 \\
\hline 18 & Recuperative burners & 1.16 & 0.12 & 3.17 & $56 \%$ & 1.8 \\
\hline 19 & Recovery of blast furnace gas & 1.39 & 0.04 & 3.20 & $44 \%$ & 2.3 \\
\hline 20 & Sinter plant heat recovery & 1.82 & 0.12 & 3.32 & $34 \%$ & 2.8 \\
\hline 21 & Thin slab casting & 1.87 & 0.98 & 4.30 & $31 \%$ & 3.3 \\
\hline 22 & Energy-efficient drives in the rolling mill & 1.96 & 0.01 & 4.31 & $31 \%$ & 3.2 \\
\hline 23 & Heat recovery on the annealing line & 2.62 & 0.10 & 4.41 & $21 \%$ & 4.0 \\
\hline 24 & Cogeneration & 4.02 & 1.18 & 5.59 & $14 \%$ & 6.1 \\
\hline 25 & Reduced steam use in the pickling line & 4.77 & 0.09 & 5.67 & $6 \%$ & 7.3 \\
\hline 26 & Hot charging & 5.34 & $0 . \mathrm{Il}$ & 5.79 & $16 \%$ & 5,9 \\
\hline 27 & Recupcrator hot blast stove & 5.66 & 0.07 & 5.86 & $3 \%$ & 8.7 \\
\hline 28 & Variable speed drive on ventilation fans & 6.49 & 0.01 & 5.87 & $0 \%$ & 9.9 \\
\hline 29 & VSD: flue gas control, pumps, fans & 6.98 & 0.03 & 5.90 & $-1 \%$ & 10.7 \\
\hline 30 & BOF gas + sensible heat recovery & 7.77 & 0.92 & 6.81 & $-3 \%$ & 11.9 \\
\hline 31 & Waste heat recovery from cooling watcr & 8.21 & 0.02 & 6.84 & - & $>50$ \\
\hline 32 & Variable specd drive coke oven gas compressors & 13.11 & 0.00 & 6.84 & $-12 \%$ & 21.2 \\
\hline 33 & Coke dry quenching & 17.78 & 0.37 & 7.21 & $-7 \%$ & 35.7 \\
\hline 34 & Top pressure recovery turbines (wct type) & 18.41 & 0.06 & 7.26 & $-9 \%$ & 29.8 \\
\hline 35 & Insulation of furnaces & 20.22 & 0.04 & 7.31 & - & 31.0 \\
\hline 36 & Coal moisture control & 52.83 & 0.09 & 7.40 & - & $>50$ \\
\hline
\end{tabular}

\section{Energy Conservation Supply Curve for U.S. Secondary Steelmaking}

We identified cost-effective energy savings of $104 \mathrm{PJ}$ and carbon dioxide emissions reductions of $1.5 \mathrm{MtC}$ of carbon dioxide for secondary steelmaking in 1994 which represents $6 \%$ of total U.S. steelmaking energy use and $4 \%$ of total carbon dioxide emissions. Figure 9 ranks the secondary steelmaking measures in a conservation supply curve. Some of the main cost-effective measures for secondary steelmaking include improved process control in the hot strip mill, recuperative burners in the rolling mill, improved process control in the EAF, and preventative maintenance. Table 7 provides a list of the measures ranked by their cost of conserved energy, internal rate of return, and simple payback periods. 


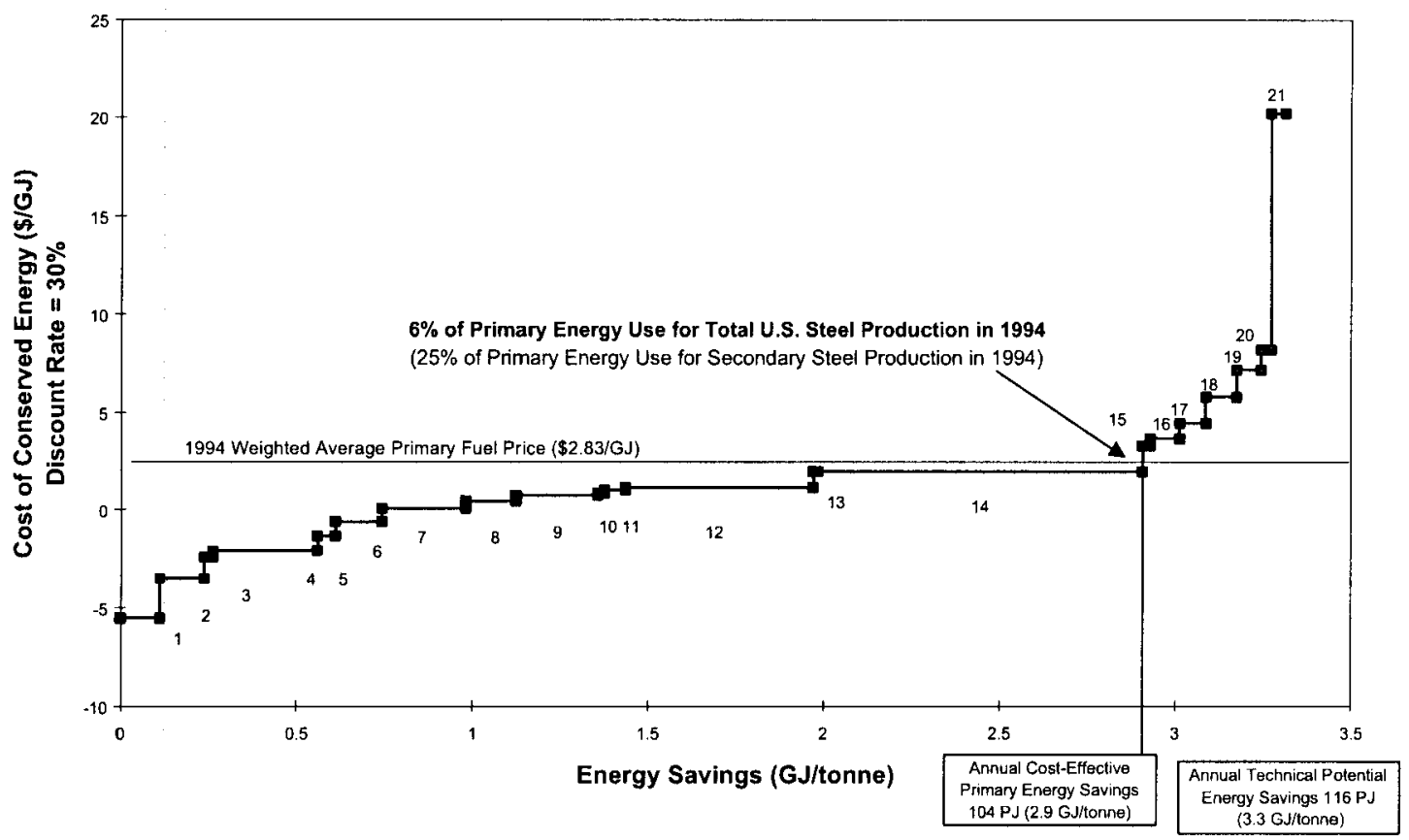

Table 7. Cost of Conserved Energy for Selected Measures in Secondary Steelmaking.

\begin{tabular}{|c|c|c|c|c|c|c|}
\hline & \multirow[t]{2}{*}{ Secondary Steelmaking Efriciency Measure } & $\begin{array}{l}\text { Primary } \\
\text { CCE }\end{array}$ & $\begin{array}{l}\text { Primary } \\
\text { Energy } \\
\text { Savings } \\
\end{array}$ & $\begin{array}{c}\text { Cumulative } \\
\text { Primary Energy } \\
\text { Savings } \\
\end{array}$ & $\begin{array}{c}\text { Internal Rate } \\
\text { of Return }\end{array}$ & $\begin{array}{c}\text { Simple } \\
\text { Payback } \\
\text { Time } \\
\end{array}$ \\
\hline & & $(\$ / G J)$ & (GJ/tonne) & (GJ/tonne) & $(\%)$ & (Years) \\
\hline 1 & Oxy-fuel burners & -5.52 & 0.11 & 0.11 & $109 \%$ & 0.9 \\
\hline 2 & $\begin{array}{l}\text { Scrap preheating, post combustion - Shaft furnace } \\
\text { (FUCHS) }\end{array}$ & -3.49 & 0.13 & 0.24 & $96 \%$ & 1.0 \\
\hline 3 & Bottom Stirring / Stirring gas injection & -2.42 & 0.02 & 0.26 & $171 \%$ & 0.2 \\
\hline 4 & Improved process control (ncural network) & -2.08 & 0.30 & 0.56 & $204 \%$ & 0.5 \\
\hline 5 & DC-Arc furnace & -1.33 & 0.05 & 0.61 & $136 \%$ & 0.7 \\
\hline 6 & Scrap preheating - Tunnel furnace (CONSTEEL) & -0.60 & 0.13 & 0.74 & $76 \%$ & 1.3 \\
\hline 7 & Preventative maintenance & 0.10 & 0.24 & 0.98 & $>500 \%$ & 0.0 \\
\hline 8 & $\begin{array}{l}\text { Controlling oxygen levels and VSDs on combustion } \\
\text { air fans }\end{array}$ & 0.46 & 0.14 & 1.12 & $187 \%$ & 0.5 \\
\hline 9 & Process control in hot strip mill & 0.75 & 0.23 & 1.35 & $121 \%$ & 0.8 \\
\hline 10 & Efficient ladle preheating & 0.87 & 0.02 & 1.37 & $105 \%$ & 0.9 \\
\hline 11 & Energy monitoring and management system & 1.04 & 0.06 & 1.43 & $109 \%$ & 0.9 \\
\hline 12 & Recuperative burners & 1.16 & 0.54 & 1.97 & $79 \%$ & 1.3 \\
\hline 13 & Energy-efficient drives in the rolling mill & 1.96 & 0.01 & 1.98 & $44 \%$ & 2.3 \\
\hline 14 & Near net shape casting/thin slab casting & 1.98 & 0.92 & 2.91 & $33 \%$ & 3.0 \\
\hline 15 & Twin Shell w/ scrap preheating & 3.33 & 0.02 & 2.93 & $28 \%$ & 3.5 \\
\hline 16 & Fluegas Monitoring and Control & 3.68 & 0.08 & 3.01 & $22 \%$ & 4.3 \\
\hline 17 & Transformer efficiency - UHP transformers & 4.47 & 0.08 & 3.09 & $18 \%$ & 5.2 \\
\hline 18 & Eccentric Bottom Tapping (EBT) on existing furnace & 5.81 & 0.09 & 3.17 & $14 \%$ & 6.8 \\
\hline 19 & Foamy slag & 7.19 & 0.07 & 3.24 & $8 \%$ & 4.2 \\
\hline 20 & Waste heat recovery from cooling water & 8.21 & 0.03 & 3.27 & $-4 \%$ & 20.8 \\
\hline 21 & Insulation of furnaces & 20.22 & 0.04 & 3.31 & $-12 \%$ & 22.1 \\
\hline
\end{tabular}

Energy Conservation Supply Curve for Total Steelmaking (Blast Furnaces and Steel Mills - SIC 33I2)

Adding the integrated and secondary steelmaking cost-effective potentials, we identified energy savings of $18 \%$ 
and carbon dioxide emissions reductions of $19 \%$ for U.S. iron and steelmaking. Figure 10 provides a summary supply curve for both integrated and secondary steelmaking combined. The savings in energy intensity are added using weighted intensity values, weighted by either the share of integrated or secondary steelmaking, depending upon which of these process can be made more efficient using the particular measure. Table 8 provides summary information on total cost-effective energy savings and carbon dioxide emissions reductions for the U.S. iron and steelmaking sector in 1994.

Figure 10. Energy Conservation Supply Curve for Total Steelmaking.

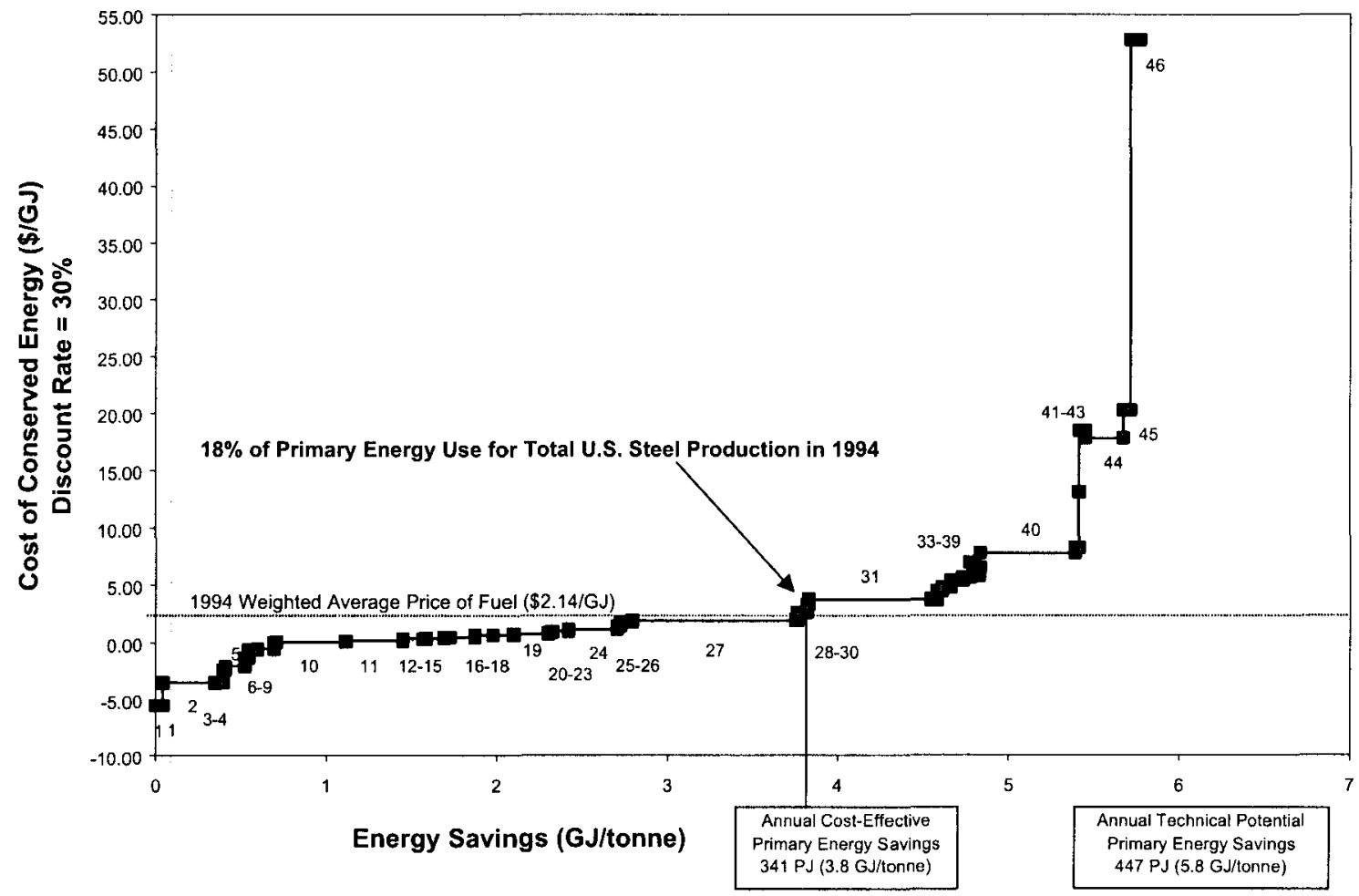

Table 8. Summary of Cost-Effective 1994 Energy Savings and Carbon Dioxide Emission Reductions. ${ }^{33}$

\begin{tabular}{l|c|c|c|c|c|c} 
& $\begin{array}{c}\text { Crude } \\
\text { Steel } \\
\text { Steelmaking }\end{array}$ & $\begin{array}{c}\text { Reduction in } \\
\text { Energy } \\
\text { Intensity } \\
(\mathrm{GJ} / \mathrm{t})\end{array}$ & $\begin{array}{c}\text { Reduction in } \\
\text { Primary } \\
\text { Energy Use* } \\
(\mathrm{MJ})\end{array}$ & $\begin{array}{c}\text { Share of Total } \\
\text { U.S. Iron and } \\
\text { Steel Primary } \\
\text { Energy Use } \\
(\%)\end{array}$ & $\begin{array}{c}\text { Reduction in } \\
\text { Carbon } \\
\text { Dioxide } \\
\text { Emissions } \\
(\mathrm{MtC})\end{array}$ & $\begin{array}{c}\text { Share of Total } \\
\text { U.S. Iron and } \\
\text { Steel }\end{array}$ \\
$\begin{array}{l}\text { Carbon Dioxide } \\
\text { Emissions (\%) }\end{array}$ \\
\hline Integrated & 55.4 & 4.3 & 236 & $13 \%$ & 5.0 & $15 \%$ \\
\hline Secondary & 35.9 & 2.9 & 104 & $6 \%$ & 1.5 & $4 \%$ \\
\hline Total & 91.2 & 3.8 & 341 & $18 \%$ & 6.5 & $19 \%$ \\
\hline
\end{tabular}

* Primary energy is calculated using a conversion rate from final to primary electricity of 3.08 , reflecting the difference between an average power plant heat rate of $10,500 \mathrm{Btu} / \mathrm{kWh}$ and a site rate of $3412 \mathrm{Btu} / \mathrm{kWh}$, including transmission and distribution losses.

\footnotetext{
${ }^{33}$ Although we used a $30 \%$ discount rate for our analysis to reflect industry preferences, we found that using a $15 \%$ discount rate in the analysis results in an additional cost effective energy savings for the industry of only $1 \%$ (12 PJ in integrated and 6 $\mathrm{PJ}$ in secondary steelmaking.
} 


\section{Summary and Conclusions}

Reviewing the industry as a whole (SIC 331 and SIC 332), we found that U.S. steel plants are relatively old and production has fluctuated dramatically in the recent past. Metallurgical coal is still the primary fuel for the sector but gas and electricity use has been increasing. Between 1958 and 1994, physical energy intensity for iron and steelmaking (SIC 331, 332) dropped $27 \%$, from $35.6 \mathrm{GJ} / \mathrm{t}$ to $25.9 \mathrm{GJ} / \mathrm{t}$, while carbon dioxide intensity (carbon dioxide emissions per tonne of steel) dropped $27 \%$ from $0.88 \mathrm{tC} / \mathrm{t}$ to $0.50 \mathrm{tC} / \mathrm{t}$. Compared to other large steel producers, the U.S. still tends to have higher energy intensities and has a large technical potential to achieve best practice levels of energy use for steel production.

In a detailed analysis of U.S. blast furnaces and steel mills (SIC 3312 only), we examined over 45 specific energy efficiency technologies and measures and estimated energy savings, carbon dioxide savings, investment costs, and operation and maintenance costs for each of these measures. Based on this information, we constructed a conservation supply curve for U.S. iron and steelmaking that found a total cost-effective reduction of $3.8 \mathrm{GJ} / \mathrm{t}$, equivalent to an achievable energy savings of $18 \%$ of 1994 U.S. iron and steel energy use and 19\% of 1994 U.S. iron and steel carbon dioxide emissions. We believe that this estimate is conservative since we may not have included all possible efficiency measures, we do not include for synergistic effects of lowered costs when investing in multiple technology upgrades at the same time, and costs that were reported in the trade literature or demonstration project may be different than average or typical costs for these particular measures.

Additional work needed to improve these energy conservation supply curve savings estimates includes the need for more detailed energy consumption information for the sector by process (especially for casting and rolling), understanding the differences in statistical information on energy use in the industry, gaining additional information on investment and operations costs for the measures, and finally, improved information on characterizing the existing technological disposition of the industry. Given the fact that the steel industry continues to evolve (for example $12 \mathrm{Mt}$ of new EAF capacity has been added since 1994), additional updates of a technology analysis would need to reflect this trend.

\section{Funding Statement}

This work was supported by the Climate Protection Division, Office of Air and Radiation, U.S. Environmental Protection Agency through the U.S. Department of Energy under Contract No. DE-AC03-76SF00098.

\section{Acknowledgments}

The authors of this report would like to acknowledge the efforts of several people. In particular, we would like to acknowledge the input of Jeremy Jones (AG Industries) and Joe Goodwill and Jennifer Kochis (EPRI Center for Materials Production) for providing their insights as well as useful documentation on energy efficiency in steelmaking, Peter Koros and other staff from LTV's Technology Center for sharing their expertise on integrated steelmaking, Libor Rostik and other staff from Chaparral Steel for their expertise on secondary steelmaking. We also thank Cliff Hanes (USS/Kobe Steel) for his review of the technologies, Jonathan Koomey (LBNL) for his review and knowledge of conservation supply curve analysis, Alan Fine (Univ. of Kentucky) and John Molburg (ANL) for their review of the report. We also thank the participants of the Technology Peer Review Workshop for the Iron and Steel Industry (Washington, DC, February 11, 1999) for their feedback, and sharing their insights with us. We acknowledge the work of Dan Einstein and Marta Khrushch to characterize the benefits of efficiency measures, and the technical support in data analysis and document production by Bryan Lehman. 


\section{References}

Adolph, A., G. Paul, K.H. Klein, E. Lepoutre, J.C. Vuilermoz, and M. Devaux, 1990. "A New Concept for Using Oxy-Fuel Burners and Oxygen Lances to Optimize Electric Arc Furnace Operation," La Revue de Metallurgie CIT 87(1): 47-53.

Aichinger, H.M., 1993. "Gesamtenergiesituation und Wirtschaft der Stahlerzeugunde Industrie in Deutschland, Kontakstudiums der TU Clausthal," Metallurgie des Eisens - Teil 2: Stahlerzeugung, Germany: GoslarHahnenklee.

American Iron and Steel Institute, 1995. 1994 Annual Statistical Report, Washington, DC: AISI.

American Iron and Steel Institute, 1996. 1995 Annual Statistical Report, Washington, DC: AISI.

American Iron and Steel Institute, 1997. 1996 Annual Statistical Report, Washington, DC: AISI.

American Iron and Steel Institute, various years. Annual Statistical Report, Washington, DC: AISI.

Ang, B.W., 1995. "Decomposition Methodology in Industrial Energy Demand Analysis," Energy 20(11): 10811096.

Anonymous, 1994. "Energy Saving VSD Quench Pumps," Steel Times, April: 150.

Anonymous, 1995. "Natural Gas Injection Tests Show Benefits," Iron \& Steelmaker 22(10): 12.

Anonymous, 1996. "BS announces 70M pound Investment," Ironmaking and Steelmaking," 23(1).

Anonymous, 1997a. "\$137 Million Expansion Project to Increase Capacity to 1.5 Mt," Iron \& Steel Maker 24(2).

Anonymous, 1997b. "Hoogovens envisage l'installation d'une coulee continue des brames minces," La Revue de Metallurgie-CIT 94(3): 583

Anonymous, 1997c. "Warmtekrachteenheid van 144 MWe bij Hoogovens" Energie en Milieuspectrum, October 1997, p.9

Argonne National Laboratory, 1982. Energy and Materials Flows in the Iron and Steel Industry. Argonne National Laboratory, IL.

Beentjes, P.A., S.P.A.M. Wokke, and J. van Breda, 1989. "Benefits of Automation of Hot Blast Stove Operation," Proceedings 1989 AISE Iron and Steel Exposition and Annual Convention, September, 18-21, 1989, Pittsburgh, PA: AISE.

Blok, K., E. Worrell, R.F.A. Cuelenaere, W.C. Turkenburg, 1993. "The Cost-Effectiveness of Carbon Dioxide Emission Reduction Achieved by Energy Conservation," Energy Policy 21(6): 656-667.

Bock, M., Boyd, G., Karlson, S., and Ross, M., 1994. "Best Practice Electricity Use in Steel Minimills," Iron and Steelmaker 21 (5): 63-66.

Bosley, J. and D. Klesser,1991. The Consteel Scrap Preheating Process, CMP Report 91-9, Center for Materials Production, Pittsburgh, PA.

Bouman, R.W. 1983. "Energy Requirements for Ironmaking and Steelmaking," Iron and Steelmaker. January.

Brown, H. et al., 1985. Energy Analysis of 108 Industrial Processes. Washington, DC: U.S. DOE. 
CADDET, 1987. A Horizontal Ladle Preheating Station fired with a Self-Recuperative Burner Improves Steel Production Operations, (Project 2B.F06.1451.87.UK), Sittard, The Netherlands: CADDET.

CADDET, 1989. "Improved Design for Foundry Ladle Pre-Heaters," CADDET Energy Efficiency Register 3.0 (project UK-89-003), Sittard, The Netherlands: CADDET.

CADDET, 1990a. "Energy Saving by Scale Removal from Charging Slab," CADDET Energy Efficiency Register 3.0 (project JP-90-022), Sittard, The Netherlands: CADDET.

CADDET, 1990b. "Computer-based Monitoring and Targeting on a Rolling Mill," Result 139 (Project UK 90.056/2B.FO3), Sittard, The Netherlands: CADDET.

Caddet, 1994. "Variable Speed Drive on a Large Continuous Furnace Combustion Air Fan," CADDET Energy Efficiency Register 3.0 (project UK-94-452), Sittard, The Netherlands: CADDET.

Caffal, C., 1995. "Energy Management in Industry," CADDET Analyses Series 17, Sittard, The Netherlands: Caddet.

Center for Materials Production, 1987. Technoeconomic Assessment of Electric Steelmaking Through the Year 2000, EPRI/CMP, Report 2787-2, October 1987.

Center for Materials Production, 1991. Direct Current Electric Arc Furnaces, Tech Commentary CMP-063, CMP, Pittsburgh, PA.

Center for Materials Production, 1992. Electric Arc Furnace Efficiency, EPRI/CMP, Report 92-10, Pittsburgh, PA: CMP.

Center for Materials Production, 1995. Coal \& Oxygen Injection in Electric Arc Furnaces, Tech Bulletin CMP 957TB, CMP, Pittsburgh, PA.

Center for Materials Production. 1997. Electric Arc Furnace Scrap Preheating. Tech Commentary, Pittsburgh, PA: Carnegie Mellon Research Institute.

Cores, A., A. Formoso, M. Sirgado, J. L. Verduras, and L. Calleja. 1996. "Recovery of Potential Thermal Energy of Rolling Mill Waste Oil Through Sintering," Ironmaking and Steelmaking 23(6): 486-492.

Dawson, P.R., 1993. "Recent Developments in Iron Ore Sintering, Part 4: The Sintering Process," Ironmaking and Steelmaking 20(2): 150-159.

de Almeida, A. and P. Fonsesca, 1997. "Characterisation of the Electricity Use in European Union and the Savings Potential 2010," in: A. de Almeida, P. Bertoldi and W. Leonhard (eds.), Energy Efficiency Improvements in Electric Motors and Drives, Berlin, Germany: Springer Verlag.

de Beer, J.G., M.T. van Wees, E. Worrell and K. Blok, 1994. ICARUS-3, The Potential of Energy Efficiency Improvement in The Netherlands from 1990 to 2000 and 2015, Utrecht, The Netherlands: Department of Science, Technology \& Society, Utrecht University.

de Beer, J.G., E. Worrell, and K. Blok, 1996. "Sectoral Potentials for Energy Efficiency Improvement in The Netherlands," Int. J. of Global Energy Issues 8 (5/6): 476-491.

Derycke, J., R. Bekaert, P. Cousein, L. Bonte, and H. Bruneel, 1990. "Automation of Hot Blast Stove Operation at Sidmar: Control and Optimisation of Energy Consumption," Ironmaking and Steelmaking 17(2): 135-138. 
Difiglio, C., Duleep, K.G., and Greene, D.L., 1990. "Cost Effectiveness of Future Fuel Economy Improvements," Energy Journal 11(1): 65-86.

Douglas, J.,1993. “New technologies for Electric Steelmaking" EPRI Journal, October/ November 1993, pp.7-15.

Dungs, H. and U. Tschirner, 1994. "Energy and Material Conversion in Coke Dry Quenching Plants as Found in Existing Facilities," Cokemaking International 6(1): 19-29.

Electric Power Research Institute, 1990. Efficient Electricity Use: Estimates of Maximum Energy Savings. Palo Alto, CA: EPRI.

Energetics, Inc. 1988. The U.S. Steel Industry: An Energy Perspective. Washington, DC: Energetics.

ETSU, 1992. "Reduction of Costs Using an Advanced Energy Management System," Best Practice Programme, $R \& D$ Profile 33, Harwell, UK: ETSU

Farla, J.C.M., E. Worrell, L. Hein, and K. Blok, 1998. Actual Implementation of Energy Conservation Measures in the Manufacturing Industry 1980-1994, The Netherlands: Dept. of Science, Technology \& Society, Utrecht University.

Fitzgerald, F., 1992. "Energy Use and Management in British Steel Plc.," Ironmaking and Steelmaking 19(2): 98106.

Flanagan, J.M., 1993. "Process Heating in the Metals Industry," CADDET Analyses Series 11, Sittard, The Netherlands: CADDET.

Flemming, G., 1995. Personal Communication with G. Flemming, SMS, Dusseldorf, Germany.

Gitman, G., 1998. American Combustion, Inc., Personal Communication, August 12 ${ }^{\text {th }}, 1998$.

Gregory, D.S., D.K. Ferguson, E. Slootman, F. Viraize and J. Luckhoff, 1996. "Results of ALARC-PC® PostCombustion at Cascade Steel Rollong Mills" Iron \& Steelmaker 23(5):49-54.

Haissig, M.,1994. "Enhancement of EAF Performance by Injection Technology" Steel Times, October 1994 pp.391-393.

Hanes, C., 1999. USS/Kobe Steel, Personal communication, June 1999.

Heesen, G.J. and D.H. Burggraaf, 1991. "New Process Control System of Hoogoven's Hot Strip Mill - Key to Improved Product Quality," Ironmaking and Steelmaking 18(3): 190-195

Hendriks, C.A.,1994. Carbon Dioxide Removal From Coal-Fired Power Plants, Kluwer Academic Publishers, Dordrecht, The Netherlands.

Herin, H.H. and T. Busbee, 1996. "The Consteel ${ }^{\circledR}$ Process in Operation at Florida Steel" Iron \& Steelmaker 23(2): 43-46.

Hofer, L.,1996. Electric Steelmaking with FUCHS Shaft Furnace Technology, Linz, Austria: Voest Alpine Industrieanlagenbau Gmbh, VAI.

Hofer, L.,1997. Personal communication, Voest Alpine Industrieanlagenbau Gmbh, Linz, Austria, 25 September 1997. 
Hogan, W. T. 1987. Minimills and Integrated Mills: A Comparison of Steelmaking in the United States. Lexington MA: Lexington Books.

Hogan, W.T., 1992. Capital Investment in Steel, A World Plan for the 1990's, New York, NY: Lexington Books.

Hogan, W.T., and F.T. Koelble, 1996a. “Fewer Blast Furnaces, but Higher Productivity,” New Steel 12(11): 62-66.

Hogan, W.T., and F.T. Koelble, 1996b. "Steel's Coke Deficit: 5.6 Million Tons and Growing," New Steel 12(12): $50-60$.

Inoue, K., 1995. "The Steel Industry in Japan: Progress in Continuous Casting," in Energy Efficiency Utilizing High Technology: As Assessment of Energy Use in Industry and Buildings, Appendix A: Case Studies, by M.D. Levine, E. Worrell, L. Price, N. Martin. London: World Energy Council.

Interlaboratory Working Group on Energy-Efficient and Low-Carbon Technologies, 1997. Scenarios of U.S. Carbon Reductions: Potential Impacts of Energy Technologies by 2010 and Beyond. Oak Ridge, TN: Office of Scientific and Technical Information.

International Energy Agency, 1995. Energy Prices and Taxes, First Quarter 1995, Paris: IEA.

International Iron and Steel Institute, Committee on Technology, 1982. Energy and the Steel Industry, Brussels, Belgium: IISI.

International Iron and Steel Institute, 1990. Statistics on Energy in the Steel Industry (1990 Update), Brussels, Belgium: IISI.

International Iron and Steel Institute, 1993. World Cokemaking Capacity, Brussels, Belgium: IISI.

International Iron and Steel Institute, 1996a. Steel Statistical Yearbook 1995. Brussels, Belgium: IISI.

International Iron and Steel Institute, 1996b. Statistics on Energy in the Steel Industry, 1996 Update. Brussels, Belgium: IISI.

I\&SM, 1997a. "Iron \& Steelmaker's 1997 Blast Furnace Roundup," Iron and Steelmaker 24(8): 24-2

I\&SM, 1997b. "Electric Arc Furnace Roundup - United States," Iron and Steelmaker 24(5): 20-39.

Janz, J. and W. Weis, 1996. "Injection of Waste Plastics into the Blast Furnace of Stahlwerke Bremen," La Revue de Metallurgie-CIT 93(10): 1219-1226.

Jones, J.A.T., 1993. Increased EAF Productivity through Improved Operating Efficiency, Nupro Corporation.

Jones, J. A. T. 1996. "New Steel Melting Technologies: Part III, Application of Oxygen Lancing in the EAF." Iron and Steelmaker 23(6): 41-42.

Jones, J. A. T. 1997a. "New Steel Melting Technologies: Part X, New EAF Melting Processes." Iron and Steelmaker 24(January): 45-46.

Jones, J. A. T. 1997b. Electric Arc Furnace Evolution: In Search of the Optimal Design. Bechtel Corporation..

Jones, J. A. T. 1997c. "New Steel Melting Technologies: Part XVI, CONSTEEL Process." Iron and Steelmaker 24(July): 47-48. 
Jones, J. A. T. 1997d. "New Steel Melting Technologies: Part XV, Fuchs Shaft Furnace." Iron and Steelmaker 24(June): 43-45.

Jones, J.A.T., 1998. Acutus Gladwin, Personal Communication, August $8^{\text {th }}, 1998$.

Kimmerling, K.,1997. Personal communication and reference list, Neural Applications Corporation, Coralville, IA (26 August 1997).

Kleimt, B. and S. Koehle, 1997. "Power Consumption of Electric Arc Furnaces with Post-Combustion" Metallurgical Plant \& Technology International 3: 56-57.

Koomey, J.G., Atkinson, C., Meier, A., McMahon, J.E. Boghosian, S., Atkinson, B., Turiel, I., Levine, M.D., Nordman, B., and Chan, P., 1991. The Potential for Electricity Efficiency Improvements in the U.S. Residential Sector. Berkeley, CA: Lawrence Berkeley National Laboratory (LBL-30477).

Krause, F., D. Olivier, and J. G. Koomey, 1995. Negawatt Power: The Cost and Potential of Electrical Efficiency in Western Europe, El Cerrito: International Project for Sustainable Energy Paths.

Kowalski, W., K-H. Peters, W. Cronert, P. Kuhn, and D. Sucker, 1990. "Optimierung der Brenner von Winderhitzern im Hinblick auf einen hohen CO-Ausbrand," Stahl u. Eisen 110(11); 41-50.

Lahita, J.A.,1995. "The Consteel ${ }^{\circledR}$ Process in Operation at New Jersey Steel Corporation" Proceedings $5^{\text {th }}$ European Electric Steel Congress, Paris, June 19-23, 1995.

Lanzer, W. and H.B. Lungen, 1996. "Roheisenerzeugung in Nordamerika," Stahl und Eisen 116(8): 61-69.

Lawrence Berkeley National Laboratory, International Energy Studies, 1998. OECD Database. Berkeley, CA: LBNL.

Ledbetter, M. and Ross, M., 1989. Supply Curves of Conserved Energy For Automobiles. Washington, DC: American Council for an Energy-Efficient Economy.

Macauley, D. and R.M. Smailer, 1997. "Engineering Fundamentals for a Least Cost/Flexible Steelmaking Solution" Paper presented at $25^{\text {th }}$ Advanced Technology Symposium on New Melting Technologies, St. Petersburg Beach, FL, May 11-14, 1997.

McAloon, T.P., 1994. “Alternate Ironmaking Update," Iron \& Steelmaker 21(2): 37-39 + 55.

Meier, A., Wright, J., and Rosenfeld, A.H., 1983. Supplying Energy Through Greater Efficiency: The Potential for Conservation in California's Residential Sector. Berkeley, CA: University of California Press.

Meijer, H.K.A., G.A. Flierman, C.P. Teerhuis, J.G. Bernard, and R. Boom, 1994. "The Cyclone Converter Furnace," Proc. Ironmaking 2000, 18th Advanced Technology Symposium, October, Myrtle Beach, SC, USA.

Meunier, H. and M. Cambier, 1993. "Use of Furnace Modelling to Improve Energy Efficiency in the Deepdrawing Steel Sheet Industry," P.A. Pilavachi (ed.), Energy Efficiency in Process Technology, Amsterdam: Elsevier Applied Science.

Midrex, 1993. The Midrex Direct Reduction Process, Charlotte, NC: Midrex Direct Reduction Corporation.

Midrex, 1995. 1994 World Direct Reduction Statistics, Charlotte, NC: Midrex Direct Reduction Corporation. 
Mitsubishi Heavy Industries, 1993. High Efficiency From Low BTU Gas, Outline of 145 MW Combined Cycle Power Plant for Kawasaki Steel Corporation, Chiba Works, Mitsubishi Heavy Industries, Ltd,, Tokyo, Japan.

Mueller, E.G.,1997. "High Production Meltshops: Trends and Innovations" Paper presented at $25^{\text {th }}$ Advanced Technology Symposium on New Melting Technologies, St. Petersburg Beach, FL, May 11-14, 1997.

Nashan, G., 1992. "Conventional Maintenance and the Renewal of Cokemaking Technology," In: IISI, Committee on Technology, The Life of Coke Ovens and New Coking Processes under Development, Brussels; IISI.

National Academy of Sciences, 1992. Policy Implications of Greenhouse Warming: Mitigation, Adaptation, and the Science Base. Washington, DC: National Academy Press.

Nelson, K., 1994. "Finding and Implementing Projects that Reduce Waste," in: R. Socolow, C. Andrews, F. Berkhout and V. Thomas, Industrial Ecology and Global Change, Cambridge, UK: Cambridge University Press.

Ninneman, P., 1997. "New Melt Shops and Rolling Mills" New Steel 13 (9): pp.40-58.

Oshnock, T.W., 1995a. "Pulverized Coal Injection for Blast Furnace Operation, Part IV," Iron \& Steelmaker 22(2): 41-42.

Oshnock, T.W., 1995b. "Pulverized Coal Injection for Blast Furnace Operation, Part VI," Iron \& Steelmaker 22(4): 49-50.

Palasios, J.M. and J.L. Arana,1995. "Research and Development of the EAF in Europe" Proceedings $5^{\text {th }}$ European Electric Steel Congress, Paris, June 19-23, 1995, pp.391-400.

Parodi, G.G., 1993. "Near Net Shape Casting of Flat Products," in: Proceedings $27^{\text {th }}$ Annual Meetings and Conference, International Iron and Steel Institute, Paris, 3-6 October, Brussels, Belgium: IISI.

Pisila, E., S: Kallo, T. Ahalo, and K. Heinanen, 1995. "High Productivity Operation of Rautaruukki Blast Furnaces," La Revue de Metallurgie-CIT 92(3): 375-380.

Price, L., Worrell, E., Martin, N., Farla, J., Schaeffer, R., 1997. "Energy Efficiency in the United States Iron and Steel Industry," Proceedings of the 1997 American Council for an Energy-Efficient Economy Summer Study on Energy Efficiency in Industry, Washington, DC: ACEEE.

Rengersen, J, Oosterhuis, E., de Boer, W.F., Veel, T.J.M. and Otto, J. 1995. "First Industrial Experience with Partial Waste Gas Recirculation in a Sinter Plant," Revue de Metallurgie-CIT 392 pp. 329-335 (1995).

Riley, M.F. and S.K. Sharma,1987. "An Evaluation of the Technical and Economic Benefits of Submerged Inert Gas Stirring in an Electric Arc Furnace" Iron \& Steelmaker 14(6): 27-32.

Ritt, A., 1996a. "The Benefits of Hot-Charging Slabs," New Steel 12(7): 34-37+44.

Ritt, A.,1996b. "Building More Powerful Melt Shops," New Steel 12(11).

Ritt, A., 1997. “Acme Rolls 0.030 Inch Hot Band,” New Steel 13(5).

Roederer, C. and L. Gourtsoyannis, 1996. Coordinated Study Steel-Environment, Luxembourg: European Commission, DG-XII. 
Rosenberg, M, 1997. "The United States Motor Systems Baseline: Inventory and Trends," in: A. de Almeida, P. Bertoldi and W. Leonhard (eds.), Energy Efficiency Improvements in Electric Motors and Drives, Berlin, Germany: Springer Verlag.

Rosenfeld, A.H., Atkinson, C., Koomey, J.G., Meier, A., Mowris, R., and Price, L., 1991. "Conserved Energy Supply Curves," Contemporary Policy Issues XI(1): 45-68.

Ross, M., 1987. "Industrial Energy Conservation and the Steel Industry of the United States," Energy 12(10/11): $1135-1152$

Ross, M., 1990. "Conservation Supply Curves for Manufacturing," Proceedings of the $25^{\text {th }}$ Intersociety Energy Conversion Engineering Conference. New York: American Institute of Chemical Engineers.

Ross, M. and Liu, 1991. "The Energy Efficiency of the Steel Industry in China," Energy 16(5): 833-848.

Schade, R.J.,1991. Bottom Stirring in an Electric Arc Furnace, Center for Metals Production, Pittsburgh, PA, February 1991.

Schorsch, L. L., 1996. "Why Minimills Give the U.S. Huge Advantages in Steel," McKinsey Quarterly (2):44-55.

Schriefer, J., 1996. “Improving Quality by Better Process Control,” New Steel 12(4): 81-83.

Schriefer, J., 1997. "Reaping the Value from Dust and Slag," New Steel 13(2): 24-33.

Schuett, K.J., and D.G. White, 1997. "Record Production on U.S. Steel Gary Works' No. 13 Blast Furnce with 450 Pounds/THM Co-Injection Rates," Iron and Steelmaker, 24(3): 65-68.

Serjeantson, R., R. Cordero and H. Cooke, 1987. Iron and Steel Works of the World, $9^{\text {th }}$ edition, Worcester Park, UK: Metal Bulletin Books Ltd.

Staib, W.E. and N.G. Bliss, 1995. "Neural Network Control System for Electric Arc Furnaces" Metallurgical Plant \& Technology International 2: 58-61.

Stelco, 1993. Present and Future Use of Energy in the Canadian Steel Industry, Ottawa, Canada: CANMET.

Stockmeyer, R., K-H. Heinen, H. Veuhoff, and H. Siegert, 1990. "Einsparung von elektrischer Energie am Lichtbogenofen durch eine neue Ausqualmregelung" Stahl u. Eisen 110(12): 113-116.

Takano, H., Kitauchi, Y., and Hiura, H., 1989. Design for the 145 MW Blast Furnace Gas Firing Gas Turbine Combined Cycle Plant," Journal of Engineering for Gas Turbines and Power, 111 (April): 218-224.

Teoh, L.L., 1989. "Electric Arc Furnace Technology: Recent Developments and Future Trends" Ironmaking and Steelmaking 16(5): 303-313.

Uemastsu, H., 1989. "Control of Operation and Equipment Prevents Coke Oven Damage," Ironmaking Conference Proceedings, Warrendale, PA: Iron and Steel Society.

U.S. Department of Energy, Energy Information Administration, 1994. Manufacturing Consumption of Energy 1991. Washington, DC: U.S. DOE, EIA.

U.S. Department of Energy, Energy Information Administration, 1995a. Measuring Energy Efficiency in the United States Economy: A Beginning. Washington, DC: U.S. DOE, EIA. 
U.S. Department of Energy, Energy Information Administration, 1995b. Monthly Energy Review. (February). Washington, DC: U.S. DOE, EIA.

U.S. Department of Energy, Energy Information Administration, 1996. Electric Sales and Revenue 1995. Washington, DC: U.S. DOE, EIA.

U.S. Department of Energy, Energy Information Administration, 1997. Manufacturing Consumption of Energy 1994. Washington, DC: U.S. DOE, EIA.

U.S. Department of Energy, Office of Industrial Technologies, 1996. Energy and Environmental Profile of the U.S. Iron and Steel Industry, Washington DC: U.S. DOE, OIT.

VAI, 1997. FUCHS Shaft Furnaces, The Power, The Performance, The Profit, Linz, Austria: Voest Alpine Industrieanlagenbau $\mathrm{Gmbh}$,

Vergote, H, 1996. "New Technologies in Process Control for Hot Strip Mills," Iron \& Steelmaker 23(2): 21-25.

Walli, R.A., 1991. Adjustable Speed Drives for Electric Arc Furnace Air Pollution Control Systems, Center for Metals Production, Pittsburgh, PA, December 1991.

Wakelin, D.H., 1997. Personal communication with David H. Wakelin, Manager of Development Engineering, LTV Cleveland Works, December 1.

Worrell, E., J.G. de Beer, and K. Blok, 1993. "Energy Conservation in the Iron and Steel Industry," in: P.A. Pilavachi (ed.), Energy Efficiency in Process Technology, Amsterdam: Elsevier Applied Science.

Worrell, E., 1994. Potentials for Improved Use of Industrial Energy and Materials. Utrecht, The Netherlands: Utrecht University.

Worrell, E., 1995. "Advanced Technologies and Energy Efficiency in the Iron and Steel Industry in China," Energy for Sustainable Development 2(4): 27-40

Worrell, E. and C. Moore, 1997. "Energy Efficiency and Advanced Technologies in the Iron and Steel Industry," in: Proceedings 1997 ACEEE Summer Study on Energy Efficiency in Industry, Washington, DC: ACEEE.

Worrell, E., Price, L., Martin, N., Farla, J., Schaeffer, R., 1997a. "Energy Intensity in the Iron and Steel Industry: A Comparison of Physical and Economic Indicators," Energy Policy 25 (7-9): 727-744.

Worrell, E., Farla, J., Price, L., Martin, N., Schaeffer, R., 1997b. "International Energy Efficiency Comparisons and Policy Implications in the Iron and Steel Industry," Proceedings of the 1997 European Council for an Energy Efficient Economy Summer Study, ECEEE.

Worrell, E., J-W. Bode, and J. De Beer, 1997c. Analysing Research and Technology Development Staretegies: The 'ATLAS' Project, Energy Efficient Technologies in Industry, Utrecht, The Netherlands: Dept. of Science, Technology \& Society, Utrecht University. 


\section{Appendix A. Description of Iron and Steelmaking Process}

Currently there are two main routes for the production of steel: production of primary steel using iron ores and scraps and production of secondary steel using scraps only. A wide variety of steel products are produced by the industry, ranging from slabs and ingots to thin sheets, which are used in turn by a large number of other manufacturing industries. Figure 1 presents a simplified scheme of the production routes.

Figure A-1. Iron and Steel Production Routes

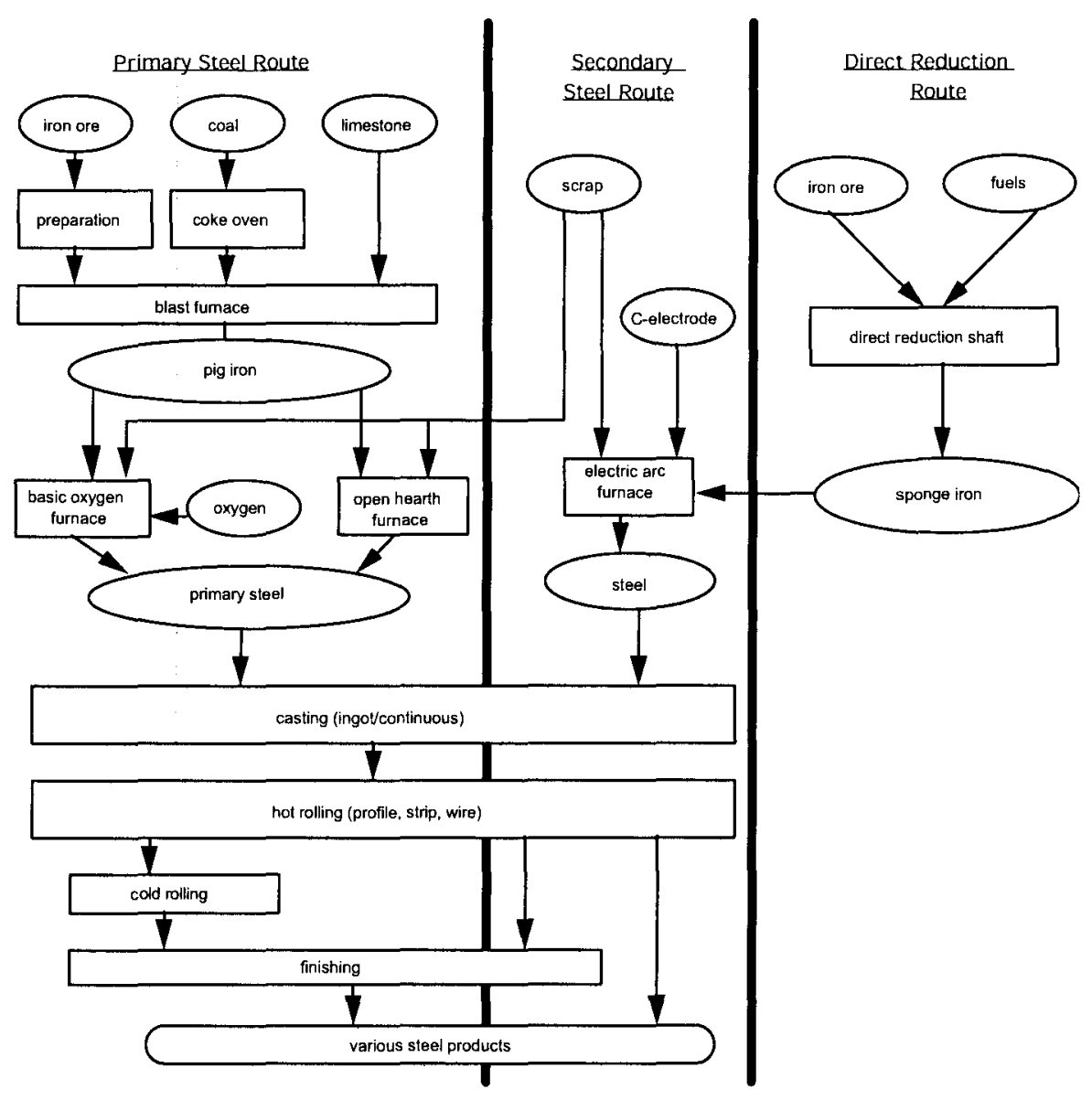

Pig iron is produced in a blast furnace, using coke in combination with injected coal or oil, to reduce sintered or pelletized iron ore to pig iron. Limestone is added as a fluxing agent. Coke is produced in coke ovens. Reduction of the iron ore is the largest energy-consuming process in the production of primary steel. Modern blast furnaces are operated at various scales, ranging from mini blast furnaces (capacity of $75 \mathrm{Ktonnes/year)} \mathrm{to} \mathrm{the} \mathrm{largest} \mathrm{with} \mathrm{a}$ capacity of 4 Mtonnes/year. Besides iron, the blast furnace also produces blast furnace gas (used for heating purposes), electricity (if top gas pressure recovery turbines are installed) and slags (used as building materials). Direct reduced iron (DRI) is produced by reduction of the ores below the melting point in small scale plants $(<1$ Mtonnes/year) and has different properties than pig iron. DRI production is growing and nearly $4 \%$ of the iron in the world is produced by direct reduction, of which over $90 \%$ uses natural gas as a fuel (Midrex, 1996). DRI serves as a high quality alternative for scrap in secondary steelmaking (see below).

Primary steel is produced by two processes: open hearth furnace (OHF) and basic oxygen furnace (BOF). The OHF is still used in different configurations, mainly in Eastern Europe, China, India and other developing countries. 
While OHF uses more energy, this process can also use more scrap than the BOF process. However, BOF process is rapidly replacing OHF worldwide, because of its greater productivity and lower capital costs. In addition, this process needs no net input of energy and can even be a net energy exporter in the form of BOF-gas and steam. The process operates through the injection of oxygen, oxidizing the carbon dioxide in the hot metal. Several configurations exist depending on the way the oxygen is injected. The steel quality can be improved further by ladle refining processes used in the steel mill.

Secondary steel is produced in an electric arc furnace (EAF) using scrap. Scrap is melted and refined, using a strong electric current. DRI can be used to enhance product quality. Several process variations exist, using either $\mathrm{AC}$ or DC currents, and fuels can be injected to reduce electricity use.

Casting and shaping are the next steps in steel production. Casting can be a batch (ingots) or a continuous process (slabs, blooms, billets). Ingot casting is the classical process and is rapidly being replaced by continuous casting machines (CCM). In 1990 nearly $60 \%$ of global crude steel production was cast continuously (IISI, 1992). The casted material can be sold as ingots or slabs to steel manufacturing industries. However, most of the steel is rolled by the steel industry to sheets, plates, tubes, profiles or wire. Generally the steel is first treated in a hot rolling mill. The steel is heated and passed through heavy roller sections reducing the thickness of the steel. Hot rolling produces profiles, sheets, or wire. After hot rolling the sheets may be reduced in thickness by cold rolling. Finishing is the final production step, and may include different processes such as annealing, pickling, and surface treatment. A more advanced technology, near net shape casting, reduces the need for hot rolling because products are cast closer to their final shape. 


\section{Appendix B. U.S. Integrated and Secondary Steel Mills}

Table B-1. 1997 Blast Furnaces in U.S. Integrated Steel Mills. Source: I\&SM, 1997a; Hogan and Koelble, 1996a.

\begin{tabular}{|c|c|c|c|c|}
\hline Company/Location & $\begin{array}{c}\text { Blast Furnace } \\
\text { Name }\end{array}$ & $\begin{array}{c}\text { Yr. built or } \\
\text { since last } \\
\text { rebuild }\end{array}$ & $\begin{array}{c}\text { Blast } \\
\text { Furnace } \\
\text { Age in } 1997 \\
\end{array}$ & $\begin{array}{c}\text { Production Rate } \\
\text { (millions of net } \\
\text { tonnes/year) }\end{array}$ \\
\hline $\begin{array}{c}\text { Acme Steel Co. } \\
\text { Chicago IL }\end{array}$ & $\begin{array}{c}\text { A } \\
\text { BS }\end{array}$ & $\begin{array}{l}1964 \\
1970\end{array}$ & $\begin{array}{l}33^{*} \\
27^{*}\end{array}$ & $\begin{array}{l}1.3 \\
0.5\end{array}$ \\
\hline $\begin{array}{l}\text { AK Steel Corp. } \\
\text { Ashland Works, Ashland KY } \\
\text { Middletown Works, Middleton OH }\end{array}$ & $\begin{array}{c}\text { Amanda } \\
3\end{array}$ & $\begin{array}{l}1963 \\
1984\end{array}$ & $\begin{array}{c}34 \\
13^{*}\end{array}$ & $\begin{array}{l}1.6 \\
2.1\end{array}$ \\
\hline $\begin{array}{l}\text { Bethlehem Steel Corp. } \\
\text { Burns Harbor Division, Burns Harbor IN } \\
\text { Sparrows Point Division, Sparrows Point MD }\end{array}$ & $\begin{array}{l}\text { C } \\
\text { D } \\
\text { L }\end{array}$ & $\begin{array}{l}1972 \\
1969 \\
1977\end{array}$ & $\begin{array}{l}25 \\
28 \\
20\end{array}$ & $\begin{array}{l}2.4 \\
2.3 \\
3.1\end{array}$ \\
\hline $\begin{array}{l}\text { Geneva Steel } \\
\text { Vineyard UT }\end{array}$ & $\begin{array}{l}1 \\
2 \\
3\end{array}$ & $\begin{array}{l}1963 \\
1963 \\
1963\end{array}$ & $\begin{array}{l}34^{*} \\
34^{*} \\
34^{*}\end{array}$ & $\begin{array}{l}0.8 \\
0.8 \\
0.8\end{array}$ \\
\hline \begin{tabular}{|l|} 
Gulf States Steel Inc. \\
Gadsden AL
\end{tabular} & 2 & 1966 & $31^{*}$ & 1.0 \\
\hline $\begin{array}{l}\text { Inland Steel Co. } \\
\text { Inland Steel Flat Products Co. } \\
\text { Indiana Harbor Works, East Chicago IN }\end{array}$ & $\begin{array}{l}5 \\
6 \\
7\end{array}$ & $\begin{array}{l}1974 \\
1976 \\
1980\end{array}$ & $\begin{array}{c}23^{*} \\
21^{*} \\
17\end{array}$ & $\begin{array}{l}0.9 \\
0.9 \\
3.3\end{array}$ \\
\hline $\begin{array}{l}\text { LTV Steel Co } \\
\text { Cleveland Works, Cleveland OH } \\
\text { Indiana Harbor Works, East Chicago IN }\end{array}$ & $\begin{array}{l}\mathrm{C}-1 \\
\mathrm{C}-5 \\
\mathrm{C}-6 \\
\mathrm{H}-3 \\
\mathrm{H}-4\end{array}$ & $\begin{array}{l}1972 \\
1990 \\
1989 \\
1988 \\
1987\end{array}$ & $\begin{array}{c}25^{*} \\
7^{*} \\
8^{*} \\
9^{*} \\
10^{*}\end{array}$ & $\begin{array}{l}1.1 \\
1.4 \\
1.4 \\
1.4 \\
1.7\end{array}$ \\
\hline $\begin{array}{l}\text { National Steel Corp. } \\
\text { Great Lakes Division, Ecore MI } \\
\text { Granite City Division, Granite City IL }\end{array}$ & $\begin{array}{c}\text { A-1 } \\
\text { B-2 } \\
\text { D-4 } \\
\text { A } \\
\text { B }\end{array}$ & $\begin{array}{l}1954 \\
1951 \\
1952 \\
1956 \\
1961\end{array}$ & $\begin{array}{l}43 \\
46 \\
45 \\
41 \\
36\end{array}$ & $\begin{array}{l}1.0 \\
0.8 \\
1.1 \\
1.0 \\
1.1\end{array}$ \\
\hline $\begin{array}{c}\text { Rouge Steel Co. } \\
\text { Dearborn MI }\end{array}$ & $\begin{array}{l}\mathrm{B} \\
\mathrm{C}\end{array}$ & $\begin{array}{l}1958 \\
1959\end{array}$ & $\begin{array}{l}39^{*} \\
38^{*}\end{array}$ & $\begin{array}{l}0.7 \\
1.5\end{array}$ \\
\hline $\begin{array}{l}\text { U.S. Steel Group } \\
\text { Edgar Thompson Plant, Braddock PA } \\
\text { Fairfield Works, Fairficld AL } \\
\text { Gary Works, Gary IN }\end{array}$ & $\begin{array}{c}1 \\
3 \\
8 \\
4 \\
6 \\
8 \\
13\end{array}$ & $\begin{array}{l}1943 \\
1930 \\
1978 \\
1950 \\
1947 \\
1943 \\
1974\end{array}$ & $\begin{array}{c}54^{*} \\
67^{*} \\
19 \\
47^{*} \\
50^{*} \\
54^{*} \\
23\end{array}$ & $\begin{array}{l}1.2 \\
1.1 \\
2.1 \\
1.1 \\
1.1 \\
1.1 \\
3.2\end{array}$ \\
\hline $\begin{array}{l}\text { USS/Kobe Steel Co. } \\
\text { Lorain } \mathrm{OH}\end{array}$ & $\begin{array}{l}3 \\
4\end{array}$ & $\begin{array}{l}1959 \\
1962\end{array}$ & $\begin{array}{l}38^{*} \\
35^{*}\end{array}$ & $\begin{array}{l}1.2 \\
1.1\end{array}$ \\
\hline $\begin{array}{c}\text { WCI Steel Inc. } \\
\text { Warren } \mathrm{OH}\end{array}$ & $W-1$ & 1980 & $17^{*}$ & 1.4 \\
\hline \begin{tabular}{|l|} 
Weirton Steel Corp \\
Weirton WV
\end{tabular} & $\begin{array}{l}1 \\
4\end{array}$ & $\begin{array}{l}1984 \\
1977\end{array}$ & $\begin{array}{l}13^{*} \\
20^{*}\end{array}$ & $\begin{array}{l}1.4 \\
1.2\end{array}$ \\
\hline $\begin{array}{l}\text { Wheeling-Pittsburgh Steel Corp. } \\
\text { Steubenville } \mathrm{OH}\end{array}$ & $\begin{array}{l}1 \\
5\end{array}$ & $\begin{array}{l}1991 \\
1995\end{array}$ & $\begin{array}{l}6^{*} \\
2^{*}\end{array}$ & $\begin{array}{l}0.8 \\
1.2\end{array}$ \\
\hline Total & 40 & 1968 & Avg $=29$ & 54.8 \\
\hline
\end{tabular}


Table B-2. 1994 U.S. Secondary Steel Mills. Source: I\&SM, $1997 b$.

\begin{tabular}{|c|c|c|c|c|c|c|}
\hline Company & $\begin{array}{c}\text { Plant } \\
\text { Location } \\
\text { City } \\
\end{array}$ & $\begin{array}{c}\text { Plant } \\
\text { Location } \\
\text { State } \\
\end{array}$ & $\begin{array}{c}\text { Yr. built or } \\
\text { since last } \\
\text { rebuild }\end{array}$ & $\begin{array}{c}\text { EAF Age in } \\
1997 \\
\text { (Years) } \\
\end{array}$ & $\begin{array}{c}\text { Power Consumption } \\
\text { (kWh/tonne) }\end{array}$ & $\begin{array}{c}\text { Total Nominal } \\
\text { Capacity } \\
\text { (ktonnes/year) }\end{array}$ \\
\hline ABC Rail Corp & Calera & $\mathrm{AL}$ & $\begin{array}{l}1954 \\
1970 \\
1972 \\
1972 \\
1970 \\
\end{array}$ & $\begin{array}{l}43 \\
27 \\
25 \\
25 \\
27\end{array}$ & $\begin{array}{l}551 \\
551 \\
551 \\
551 \\
551\end{array}$ & $\begin{array}{l}32 \\
32 \\
32 \\
32 \\
32\end{array}$ \\
\hline A] Tech Specialty Steel Corp & Dunkirk & NY & $\begin{array}{l}1951 \\
1951 \\
\end{array}$ & $\begin{array}{l}46 \\
46 \\
\end{array}$ & $\begin{array}{l}579 \\
579 \\
\end{array}$ & $\begin{array}{l}57 \\
57 \\
\end{array}$ \\
\hline Allegheny Teledyne Inc. & $\begin{array}{l}\text { Brackenridge } \\
\text { Latrobe } \\
\text { Lockport } \\
\text { Owensboro }\end{array}$ & $\begin{array}{l}\text { PA } \\
\\
\\
\text { PA } \\
\text { NY } \\
\\
\text { KY }\end{array}$ & $\begin{array}{l}1949 \\
1949 \\
1949 \\
1949 \\
1968 \\
1949 \\
1962 \\
1962 \\
1953 \\
1953 \\
\end{array}$ & $\begin{array}{l}48 \\
48 \\
48 \\
48 \\
29 \\
48 \\
35 \\
35 \\
44 \\
44 \\
\end{array}$ & $\begin{array}{l}551 \\
551 \\
551 \\
551 \\
524 \\
606 \\
606 \\
606 \\
573 \\
573 \\
\end{array}$ & $\begin{array}{l}113 \\
113 \\
113 \\
113 \\
54 \\
36 \\
36 \\
36 \\
50 \\
50 \\
\end{array}$ \\
\hline American Cast Iron Pipe & Birmingham & $\mathrm{AL}$ & $\begin{array}{l}1957 \\
1945 \\
1945 \\
1954 \\
\end{array}$ & $\begin{array}{l}40 \\
52 \\
52 \\
43 \\
\end{array}$ & $\begin{array}{l}689 \\
689 \\
689 \\
689 \\
\end{array}$ & $\begin{array}{c}18 \\
5 \\
5 \\
5 \\
\end{array}$ \\
\hline AmeriSteel & $\begin{array}{l}\text { Knoxville } \\
\text { Jackson } \\
\text { Charlotte } \\
\text { Baldwin } \\
\end{array}$ & $\begin{array}{l}\text { TN } \\
\text { TN } \\
\text { NC } \\
\text { FL } \\
\end{array}$ & $\begin{array}{l}1962 \\
1975 \\
1981 \\
1989 \\
1976 \\
\end{array}$ & $\begin{array}{c}35 \\
22 \\
16 \\
8 \\
21 \\
\end{array}$ & $\begin{array}{l}524 \\
524 \\
430 \\
391 \\
430 \\
\end{array}$ & $\begin{array}{l}136 \\
136 \\
544 \\
363 \\
454 \\
\end{array}$ \\
\hline Arkansas Steel Associates & Newport & $\mathrm{AR}$ & 1994 & 3 & 485 & 118 \\
\hline Armco Inc. & $\begin{array}{l}\text { Mansfield } \\
\text { Butler }\end{array}$ & $\begin{array}{l}\mathrm{OH} \\
\mathrm{PA}\end{array}$ & $\begin{array}{l}1963 \\
1987 \\
1969 \\
1969 \\
1969 \\
\end{array}$ & $\begin{array}{l}34 \\
10 \\
28 \\
28 \\
28 \\
\end{array}$ & $\begin{array}{l}464 \\
473 \\
452 \\
452 \\
452 \\
\end{array}$ & $\begin{array}{l}272 \\
381 \\
290 \\
290 \\
290 \\
\end{array}$ \\
\hline Atchison Casting Corp & Atchison & $\mathrm{KS}$ & $\begin{array}{l}1958 \\
1946 \\
1940 \\
1981 \\
\end{array}$ & $\begin{array}{l}39 \\
51 \\
57 \\
16 \\
\end{array}$ & $\begin{array}{l}507 \\
606 \\
716 \\
617 \\
\end{array}$ & $\begin{array}{l}16 \\
16 \\
16 \\
16\end{array}$ \\
\hline Auburn Steel Co. Inc. & $\begin{array}{l}\text { Auburn } \\
\text { Lemont }\end{array}$ & $\begin{array}{l}\text { NY } \\
\text { IL }\end{array}$ & $\begin{array}{l}1975 \\
1959 \\
1959 \\
\end{array}$ & $\begin{array}{l}22 \\
38 \\
38 \\
\end{array}$ & $\begin{array}{l}391 \\
513 \\
513 \\
\end{array}$ & $\begin{array}{l}390 \\
181 \\
181 \\
\end{array}$ \\
\hline Bar Technologies, Inc. & Johnstown & $\mathrm{PA}$ & 1981 & 16 & 540 & 680 \\
\hline Bayou Steel Corp. & $\begin{array}{l}\text { Rockwood } \\
\text { LaPlace } \\
\text { Rockwood } \\
\end{array}$ & $\begin{array}{l}\text { TN } \\
\text { LA } \\
\text { TN } \\
\end{array}$ & $\begin{array}{l}1966 \\
1981 \\
1981 \\
1981 \\
1974 \\
\end{array}$ & $\begin{array}{l}31 \\
16 \\
16 \\
16 \\
23 \\
\end{array}$ & $\begin{array}{l}430 \\
474 \\
594 \\
491 \\
430 \\
\end{array}$ & $\begin{array}{c}181 \\
357 \\
1043 \\
357 \\
181 \\
\end{array}$ \\
\hline Bethlehem Steel Corp & Steelton & $\overline{\mathrm{PA}}$ & $\begin{array}{l}1968 \\
1994 \\
\end{array}$ & $\begin{array}{c}29 \\
3 \\
\end{array}$ & $\begin{array}{l}485 \\
441 \\
\end{array}$ & $\begin{array}{l}499 \\
998 \\
\end{array}$ \\
\hline Birmingham Stecl Corp & \begin{tabular}{|l} 
Cartersville \\
Kankakee \\
Jackson \\
Birmingham \\
\end{tabular} & $\begin{array}{l}\text { GA } \\
\text { IL } \\
\text { MS } \\
\text { AL } \\
\end{array}$ & $\begin{array}{l}1976 \\
1990 \\
1990 \\
1993 \\
1987 \\
\end{array}$ & $\begin{array}{c}21 \\
7 \\
7 \\
4 \\
10 \\
\end{array}$ & $\begin{array}{l}595 \\
496 \\
452 \\
474 \\
457 \\
\end{array}$ & $\begin{array}{l}272 \\
816 \\
680 \\
408 \\
431 \\
\end{array}$ \\
\hline Border Steel Mills & El Paso & $\mathrm{TX}$ & $\begin{array}{l}1961 \\
1966 \\
\end{array}$ & $\begin{array}{l}36 \\
31 \\
\end{array}$ & $\begin{array}{l}496 \\
496 \\
\end{array}$ & $\begin{array}{l}113 \\
113 \\
\end{array}$ \\
\hline Calumet Steel Co. & Chicago Heights & $\mathrm{IL}$ & $\begin{array}{l}1967 \\
1967 \\
\end{array}$ & $\begin{array}{l}30 \\
30 \\
\end{array}$ & $\begin{array}{l}551 \\
551 \\
\end{array}$ & $\begin{array}{l}68 \\
68 \\
\end{array}$ \\
\hline Carpenter Technology Corp. & Reading & PA & $\begin{array}{l}1955 \\
1955 \\
1955 \\
1955 \\
1956 \\
1982 \\
\end{array}$ & $\begin{array}{l}42 \\
42 \\
42 \\
42 \\
41 \\
15 \\
\end{array}$ & $\begin{array}{l}474 \\
474 \\
474 \\
474 \\
474 \\
441 \\
\end{array}$ & $\begin{array}{c}18 \\
18 \\
18 \\
18 \\
18 \\
129 \\
\end{array}$ \\
\hline Company & $\begin{array}{c}\text { Plant } \\
\text { Location } \\
\text { City } \\
\end{array}$ & $\begin{array}{c}\begin{array}{c}\text { Plant } \\
\text { Location } \\
\text { State }\end{array} \\
\end{array}$ & $\begin{array}{l}\text { Yr. built or } \\
\text { since last } \\
\text { rebuild }\end{array}$ & $\begin{array}{c}\text { EAF Age in } \\
1997 \\
\text { (Years) } \\
\end{array}$ & $\begin{array}{c}\text { Power Consumption } \\
(\mathrm{kWh} / \text { tonne })\end{array}$ & $\begin{array}{c}\text { Total Nominal } \\
\text { Capacity } \\
\text { (ktonnes/year) }\end{array}$ \\
\hline Cascade Steel Rolling Mills & McMinnville & OR & 1991 & 6 & 452 & 635 \\
\hline Champion Steel Co. & Orwell & $\mathrm{OH}$ & 1968 & 29 & 678 & 5 \\
\hline
\end{tabular}




\begin{tabular}{|c|c|c|c|c|c|c|}
\hline $\begin{array}{l}\text { Chaparral Steel } \\
\text { Charter Manufacturing Co }\end{array}$ & $\begin{array}{l}\text { Midlothian } \\
\text { Saukville }\end{array}$ & $\begin{array}{l}\text { TX } \\
\text { WI }\end{array}$ & $\begin{array}{l}1975 \\
1981 \\
1991 \\
\end{array}$ & $\begin{array}{c}22 \\
16 \\
6 \\
\end{array}$ & $\begin{array}{l}441 \\
419 \\
551 \\
\end{array}$ & $\begin{array}{c}771 \\
1043 \\
318 \\
\end{array}$ \\
\hline CitiSteel USA Inc & Claymont & $\mathrm{DE}$ & 1989 & 8 & 468 & 363 \\
\hline CMC Steel Group & $\begin{array}{l}\text { Seguin } \\
\text { Birmingham }\end{array}$ & $\begin{array}{l}\mathrm{TX} \\
\mathrm{AL} \\
\end{array}$ & $\begin{array}{l}1992 \\
1994 \\
\end{array}$ & $\begin{array}{l}5 \\
3 \\
\end{array}$ & $\begin{array}{l}468 \\
452 \\
\end{array}$ & $\begin{array}{l}703 \\
499 \\
\end{array}$ \\
\hline Co-Steel Raritan & Perth Amboy & $\mathrm{NJ}$ & 1979 & 18 & 430 & 680 \\
\hline Crucible Materials Corp. & Syracuse & NY & $\begin{array}{l}1973 \\
1951 \\
\end{array}$ & $\begin{array}{l}24 \\
46 \\
\end{array}$ & $\begin{array}{l}518 \\
551 \\
\end{array}$ & $\begin{array}{l}45 \\
23 \\
\end{array}$ \\
\hline CSC Ltd. & Warren & $\mathrm{OH}$ & $\begin{array}{l}1976 \\
1975 \\
1975 \\
1976 \\
\end{array}$ & $\begin{array}{l}21 \\
22 \\
22 \\
21\end{array}$ & $\begin{array}{l}519 \\
521 \\
518 \\
520 \\
\end{array}$ & $\begin{array}{l}109 \\
109 \\
109 \\
109 \\
\end{array}$ \\
\hline $\mathrm{DSC}$, Inc. & Trenton & $\mathrm{MI}$ & $\begin{array}{l}1954 \\
1954\end{array}$ & $\begin{array}{l}43 \\
43\end{array}$ & $\begin{array}{l}557 \\
557\end{array}$ & $\begin{array}{l}254 \\
254\end{array}$ \\
\hline Electralloy & Oil City & $\mathrm{PA}$ & 1968 & 29 & 551 & 64 \\
\hline Ellwood Quality Steel lnc. & New Castle & $\mathrm{PA}$ & 1985 & 12 & 468 & 272 \\
\hline Eric Forge and Steel Inc. & Eric & $\mathrm{PA}$ & $\begin{array}{l}1986 \\
1966 \\
1966 \\
\end{array}$ & $\begin{array}{l}11 \\
31 \\
31 \\
\end{array}$ & $\begin{array}{l}441 \\
716 \\
595 \\
\end{array}$ & $\begin{array}{c}159 \\
32 \\
159 \\
\end{array}$ \\
\hline ESCO Corp. & $\begin{array}{l}\text { Portland } \\
\text { Newton }\end{array}$ & $\begin{array}{l}\text { OR } \\
\text { MS }\end{array}$ & $\begin{array}{l}1940 \\
1940 \\
1940 \\
1971 \\
1979 \\
\end{array}$ & $\begin{array}{l}57 \\
57 \\
57 \\
26 \\
18 \\
\end{array}$ & $\begin{array}{l}568 \\
568 \\
568 \\
463 \\
463 \\
\end{array}$ & $\begin{array}{c}13 \\
13 \\
13 \\
5 \\
5 \\
\end{array}$ \\
\hline Finkl, A., \& Sons & Chicago & IL & $\begin{array}{l}1953 \\
1953\end{array}$ & $\begin{array}{l}44 \\
44 \\
\end{array}$ & $\begin{array}{l}551 \\
551 \\
\end{array}$ & $\begin{array}{l}41 \\
41 \\
\end{array}$ \\
\hline FirstMiss Steel, Inc. & Hollsopple & $\mathrm{PA}$ & 1980 & 17 & 496 & 45 \\
\hline Georgetown Steel Corp. & Georgetown & $\mathrm{SC}$ & $\begin{array}{l}1969 \\
1969\end{array}$ & $\begin{array}{l}28 \\
28\end{array}$ & $\begin{array}{l}573 \\
573\end{array}$ & $\begin{array}{l}454 \\
454\end{array}$ \\
\hline GST Steel Co. & Kansas City & $\mathrm{MO}$ & $\begin{array}{l}1977 \\
1977\end{array}$ & $\begin{array}{l}20 \\
20\end{array}$ & $\begin{array}{l}463 \\
463\end{array}$ & $\begin{array}{l}435 \\
435 \\
\end{array}$ \\
\hline Harrison Steel Castings Co. & Attica & IN & $\begin{array}{l}1951 \\
1974 \\
1992 \\
\end{array}$ & $\begin{array}{c}46 \\
23 \\
5 \\
\end{array}$ & $\begin{array}{l}491 \\
463 \\
529 \\
\end{array}$ & $\begin{array}{l}15 \\
36 \\
36 \\
\end{array}$ \\
\hline Haynes International, Inc. & Kokomo & IN & $\begin{array}{l}1963 \\
1948 \\
\end{array}$ & $\begin{array}{l}34 \\
49 \\
\end{array}$ & $\begin{array}{l}551 \\
661 \\
\end{array}$ & $\begin{array}{l}18 \\
7 \\
\end{array}$ \\
\hline Hensley, GH & Dallas & $\mathrm{TX}$ & $\begin{array}{l}1987 \\
1989\end{array}$ & $\begin{array}{c}10 \\
8\end{array}$ & $\begin{array}{l}524 \\
524\end{array}$ & $\begin{array}{l}5 \\
5\end{array}$ \\
\hline Hoeganacs Corp. & $\begin{array}{l}\text { Gallatin } \\
\text { Riverton }\end{array}$ & $\begin{array}{l}\mathrm{TN} \\
\mathrm{NJ} \\
\end{array}$ & $\begin{array}{l}1979 \\
1970 \\
\end{array}$ & $\begin{array}{l}18 \\
27 \\
\end{array}$ & $\begin{array}{l}551 \\
551 \\
\end{array}$ & $\begin{array}{l}159 \\
102 \\
\end{array}$ \\
\hline Inland Steel Bar Co. & East Chicago & IN & 1970 & 27 & 507 & 490 \\
\hline Inmetco & Ellwood City & $\mathrm{PA}$ & 1978 & 19 & 551 & 25 \\
\hline IRI International & Pampa & $\mathrm{TX}$ & 1952 & 45 & 551 & 19 \\
\hline J\&L Specialty Steel, Inc. & Midland & $\mathrm{PA}$ & $\begin{array}{l}1980 \\
1980\end{array}$ & $\begin{array}{l}17 \\
17\end{array}$ & $\begin{array}{l}504 \\
504\end{array}$ & $\begin{array}{l}363 \\
363\end{array}$ \\
\hline K.O. Steel Foundry \& Machine & San Antonio & TX & 1979 & 18 & 546 & 22 \\
\hline Kentucky Electric Stecl Inc. & Ashland & $\overline{\mathrm{KY}}$ & $\begin{array}{l}1981 \\
1981\end{array}$ & $\begin{array}{l}16 \\
16\end{array}$ & $\begin{array}{l}590 \\
590\end{array}$ & $\begin{array}{l}140 \\
140\end{array}$ \\
\hline Keokuk Steel Castings, Inc. & Keokuk & IA & 1976 & 21 & 551 & 34 \\
\hline Keystone Steel \& Wire Co. & Peoria & IL & $\begin{array}{l}1969 \\
1970\end{array}$ & $\begin{array}{l}28 \\
27\end{array}$ & $\begin{array}{l}485 \\
485\end{array}$ & $\begin{array}{l}308 \\
308\end{array}$ \\
\hline Laclede Steel Co. & Alton & $\mathrm{IL}$ & $\begin{array}{l}1965 \\
1965\end{array}$ & $\begin{array}{l}32 \\
32\end{array}$ & $\begin{array}{l}474 \\
474\end{array}$ & $\begin{array}{l}454 \\
454\end{array}$ \\
\hline LaTourneau Inc. & Longview & TX & $\begin{array}{l}1973 \\
1973 \\
\end{array}$ & $\begin{array}{l}24 \\
24\end{array}$ & $\begin{array}{l}496 \\
496\end{array}$ & $\begin{array}{l}34 \\
34\end{array}$ \\
\hline Lone Star Steel lnc. & Lone Star & $\mathrm{TX}$ & $\begin{array}{l}1976 \\
1976\end{array}$ & $\begin{array}{l}21 \\
21\end{array}$ & $\begin{array}{l}551 \\
551\end{array}$ & $\begin{array}{l}240 \\
240\end{array}$ \\
\hline LTV Steel Co. & Cleveland & $\mathrm{OH}$ & $\begin{array}{l}1959 \\
1959 \\
\end{array}$ & $\begin{array}{l}38 \\
38 \\
\end{array}$ & $\begin{array}{l}507 \\
507\end{array}$ & $\begin{array}{l}359 \\
359\end{array}$ \\
\hline Lukens Inc. & Coatesville & $\mathrm{PA}$ & $\begin{array}{l}1985 \\
1965\end{array}$ & $\begin{array}{l}12 \\
32\end{array}$ & $\begin{array}{l}427 \\
465\end{array}$ & $\begin{array}{l}798 \\
263\end{array}$ \\
\hline
\end{tabular}




\begin{tabular}{|c|c|c|c|c|c|c|}
\hline Company & $\begin{array}{c}\text { Plant } \\
\text { Location } \\
\text { City } \\
\end{array}$ & $\begin{array}{c}\text { Plant } \\
\text { Location } \\
\text { State } \\
\end{array}$ & $\begin{array}{c}\text { Yr. built or } \\
\text { since last } \\
\text { rebuild } \\
\end{array}$ & $\begin{array}{c}\text { EAF Age in } \\
1997 \\
\text { (Years) }\end{array}$ & $\begin{array}{c}\text { Power Consumption } \\
\text { (kWh/tonne) }\end{array}$ & $\begin{array}{c}\text { Total Nominal } \\
\text { Capacity } \\
\text { (ktonnes/year) }\end{array}$ \\
\hline$\overline{\text { MACSTEEL }}$ & \begin{tabular}{|l} 
Jackson \\
Fort Smith
\end{tabular} & $\begin{array}{l}\text { MI } \\
\text { AR }\end{array}$ & $\begin{array}{l}1974 \\
1974 \\
1984 \\
1984\end{array}$ & $\begin{array}{l}23 \\
23 \\
13 \\
13\end{array}$ & $\begin{array}{l}534 \\
534 \\
463 \\
463\end{array}$ & $\begin{array}{l}236 \\
236 \\
363 \\
363\end{array}$ \\
\hline Marion Stcel Co. & Marion & $\mathrm{OH}$ & $\begin{array}{l}1976 \\
1967 \\
\end{array}$ & $\begin{array}{l}21 \\
30 \\
\end{array}$ & $\begin{array}{l}491 \\
491 \\
\end{array}$ & $\begin{array}{l}172 \\
172 \\
\end{array}$ \\
\hline Maynard Steel Casting Co & Milwaukce & WI & $\begin{array}{l}1948 \\
1982 \\
1962 \\
1957 \\
\end{array}$ & $\begin{array}{l}49 \\
15 \\
35 \\
40 \\
\end{array}$ & $\begin{array}{l}661 \\
551 \\
551 \\
551 \\
\end{array}$ & $\begin{array}{c}7 \\
16 \\
8 \\
7 \\
\end{array}$ \\
\hline National Forge Co & Irvine & PA & 1962 & 35 & 518 & 53 \\
\hline New CF\&I Inc. & Pueblo & $\mathrm{CO}$ & 1973 & 24 & 474 & 499 \\
\hline New Jersey Steel Corp. & Sayrevillc & $\mathrm{NJ}$ & 1994 & 3 & 424 & 617 \\
\hline North Star Steel Co. & \begin{tabular}{|l} 
Wilton \\
Beaumont \\
Youngstown \\
\\
Monroe \\
St. Paul \\
\end{tabular} & $\begin{array}{l}\mathrm{IA} \\
\mathrm{TX} \\
\\
\mathrm{OH} \\
\\
\mathrm{MI} \\
\mathrm{MN} \\
\end{array}$ & $\begin{array}{l}1976 \\
1976 \\
1976 \\
1986 \\
1986 \\
1980 \\
1994 \\
\end{array}$ & $\begin{array}{l}21 \\
21 \\
21 \\
11 \\
11 \\
17 \\
3 \\
\end{array}$ & $\begin{array}{l}518 \\
524 \\
524 \\
408 \\
408 \\
524 \\
524 \\
\end{array}$ & $\begin{array}{l}299 \\
381 \\
381 \\
213 \\
213 \\
544 \\
544 \\
\end{array}$ \\
\hline Northwestern Stcel \& Wirc Co. & Sterling & $\mathrm{IL}$ & $\begin{array}{l}1968 \\
1971 \\
1976 \\
\end{array}$ & $\begin{array}{l}29 \\
26 \\
21 \\
\end{array}$ & $\begin{array}{l}529 \\
529 \\
529 \\
\end{array}$ & \begin{tabular}{|l|}
862 \\
608 \\
862 \\
\end{tabular} \\
\hline NS Group Inc. & $\begin{array}{l}\text { Newport } \\
\text { Beaver Falls }\end{array}$ & $\begin{array}{l}\mathrm{KY} \\
\mathrm{PA} \\
\end{array}$ & $\begin{array}{l}1981 \\
1981 \\
1981 \\
1991 \\
\end{array}$ & $\begin{array}{c}16 \\
16 \\
16 \\
6 \\
\end{array}$ & $\begin{array}{l}575 \\
575 \\
578 \\
441 \\
\end{array}$ & $\begin{array}{l}133 \\
165 \\
208 \\
435 \\
\end{array}$ \\
\hline Nucor Corp. & \begin{tabular}{|l} 
Jewett \\
Norfolk \\
Darlington \\
Crawfordsville \\
Plymouth \\
Hickman
\end{tabular} & $\begin{array}{l}\text { SC } \\
\text { IN } \\
\text { UT } \\
\text { AR }\end{array}$ & $\begin{array}{l}1975 \\
1975 \\
1980 \\
1980 \\
1980 \\
1973 \\
1973 \\
1981 \\
1979 \\
1979 \\
1993 \\
1989 \\
1989 \\
1981 \\
1993 \\
1993 \\
\end{array}$ & $\begin{array}{l}22 \\
22 \\
17 \\
17 \\
17 \\
24 \\
24 \\
16 \\
18 \\
18 \\
4 \\
8 \\
8 \\
16 \\
4 \\
4 \\
\end{array}$ & $\begin{array}{l}474 \\
474 \\
452 \\
452 \\
474 \\
529 \\
529 \\
529 \\
529 \\
529 \\
364 \\
441 \\
441 \\
441 \\
386 \\
386 \\
\end{array}$ & $\begin{array}{l}159 \\
159 \\
168 \\
168 \\
159 \\
136 \\
136 \\
136 \\
136 \\
136 \\
635 \\
726 \\
726 \\
907 \\
907 \\
907 \\
\end{array}$ \\
\hline Nucor-Yamato Stecl Co. & Blytheville & $\mathrm{AR}$ & $\begin{array}{l}1988 \\
1988 \\
\end{array}$ & $\begin{array}{l}9 \\
9 \\
\end{array}$ & $\begin{array}{r}386 \\
386 \\
\end{array}$ & $\begin{array}{l}1134 \\
1134 \\
\end{array}$ \\
\hline Oregon Steel Mills, Inc. & $\begin{array}{l}\text { Portland } \\
\text { Pueblo }\end{array}$ & $\begin{array}{l}\mathrm{OR} \\
\mathrm{CO}\end{array}$ & $\begin{array}{l}1985 \\
1976\end{array}$ & $\begin{array}{l}12 \\
21 \\
\end{array}$ & $\begin{array}{l}474 \\
474 \\
\end{array}$ & \begin{tabular}{|l}
499 \\
499 \\
\end{tabular} \\
\hline Republic Enginecred Stecls & Canton & $\mathrm{OH}$ & $\begin{array}{l}1952 \\
1952 \\
1968 \\
1994 \\
\end{array}$ & $\begin{array}{c}45 \\
45 \\
29 \\
3 \\
\end{array}$ & $\begin{array}{l}617 \\
617 \\
551 \\
551 \\
\end{array}$ & $\begin{array}{c}86 \\
86 \\
118 \\
118 \\
\end{array}$ \\
\hline Roanoke Electric Stecl Corp. & Roanoke & VA & 1975 & 22 & 529 & 136 \\
\hline Rouge Steel Co. & Dearborn & MI & $\begin{array}{l}1976 \\
1976 \\
\end{array}$ & $\begin{array}{l}21 \\
21 \\
\end{array}$ & $\begin{array}{l}529 \\
529 \\
\end{array}$ & $\begin{array}{l}431 \\
431 \\
\end{array}$ \\
\hline Sandusky International Inc. & Sandusky & $\mathrm{OH}$ & $\begin{array}{l}1956 \\
1966 \\
\end{array}$ & $\begin{array}{r}41 \\
31 \\
\end{array}$ & $\begin{array}{l}551 \\
551\end{array}$ & $\begin{array}{l}4 \\
4 \\
\end{array}$ \\
\hline Sheffield Steel Corp. & Sand Springs & $\mathrm{OK}$ & $\begin{array}{l}1970 \\
1957 \\
\end{array}$ & $\begin{array}{l}27 \\
40\end{array}$ & $\begin{array}{l}507 \\
507 \\
\end{array}$ & $\begin{array}{l}272 \\
272 \\
\end{array}$ \\
\hline Slater Steels Corp. & Ft. Wayne & $\mathrm{IN}$ & 1942 & 55 & 496 & 18 \\
\hline SMI Steel South Caroline & Cayce & $\mathrm{SC}$ & 1992 & 5 & 496 & 318 \\
\hline Standard Steel & $\begin{array}{l}\text { Burnham } \\
\text { Latrobe }\end{array}$ & PA & $\begin{array}{l}1962 \\
1971 \\
1965 \\
1971\end{array}$ & $\begin{array}{l}35 \\
26 \\
32 \\
26\end{array}$ & $\begin{array}{l}606 \\
524 \\
579 \\
551\end{array}$ & $\begin{array}{c}52 \\
114 \\
36 \\
50\end{array}$ \\
\hline
\end{tabular}

\begin{tabular}{|c|c|c|c|c|c|c|}
\hline Company & $\begin{array}{c}\text { Plant } \\
\text { Location }\end{array}$ & $\begin{array}{c}\text { Plant } \\
\text { Location }\end{array}$ & $\begin{array}{c}\text { Yr. built or } \\
\text { since last }\end{array}$ & $\begin{array}{c}\text { EAF Age in } \\
1997\end{array}$ & $\begin{array}{c}\text { Power Consumption } \\
\text { (kWh/tonne) }\end{array}$ & $\begin{array}{c}\text { Total Nominal } \\
\text { Capacity }\end{array}$ \\
\hline
\end{tabular}




\begin{tabular}{|c|c|c|c|c|c|c|}
\hline & City & State & rebuild & (Years) & & (ktonnes/year) \\
\hline Steel of West Virginia, Inc. & Huntington & $\overline{W V}$ & $\begin{array}{l}1979 \\
1979\end{array}$ & $\begin{array}{l}18 \\
18\end{array}$ & $\begin{array}{l}551 \\
551\end{array}$ & $\begin{array}{l}91 \\
91\end{array}$ \\
\hline Texas Foundries & Lufkin & $\mathrm{TX}$ & $\begin{array}{l}1959 \\
1981\end{array}$ & $\begin{array}{l}38 \\
16 \\
\end{array}$ & $\begin{array}{l}594 \\
594\end{array}$ & $\begin{array}{l}18 \\
18\end{array}$ \\
\hline Texas Steel Co. & Ft. Worth & $T \overline{T X}$ & $\begin{array}{l}1923 \\
1942 \\
\end{array}$ & $\begin{array}{l}74 \\
55\end{array}$ & $\begin{array}{l}507 \\
496 \\
\end{array}$ & $\begin{array}{l}14 \\
23\end{array}$ \\
\hline Timken Co. & $\begin{array}{l}\text { Latrobe } \\
\text { Canton }\end{array}$ & $\begin{array}{l}\mathrm{PA} \\
\mathrm{OH}\end{array}$ & $\begin{array}{l}1964 \\
1964 \\
1976 \\
1964 \\
1971 \\
1985\end{array}$ & $\begin{array}{l}33 \\
33 \\
21 \\
33 \\
26 \\
12 \\
\end{array}$ & $\begin{array}{l}573 \\
474 \\
540 \\
540 \\
540 \\
459 \\
\end{array}$ & $\begin{array}{c}30 \\
20 \\
302 \\
302 \\
302 \\
780 \\
\end{array}$ \\
\hline Union Electric Steel Corp. & Carnegie & $\mathrm{PA}$ & 1966 & 31 & 645 & 45 \\
\hline $\begin{array}{l}\text { Universal Stainless \& Alloy Products, } \\
\text { Inc. }\end{array}$ & Bridgeville &  & 1961 & 36 & 540 & 95 \\
\hline Washington Stcel Corp. & Houston & $\overline{\mathrm{PA}}$ & $\begin{array}{l}1963 \\
1989\end{array}$ & $\begin{array}{c}34 \\
8\end{array}$ & $\begin{array}{l}524 \\
474\end{array}$ & $\begin{array}{c}90 \\
163\end{array}$ \\
\hline Worthington Industries, Inc. & Columbus & $\overline{\mathrm{OH}}$ & $\begin{array}{l}1965 \\
1978 \\
\end{array}$ & $\begin{array}{l}32 \\
19 \\
\end{array}$ & $\begin{array}{l}546 \\
546 \\
\end{array}$ & $\begin{array}{l}113 \\
100 \\
\end{array}$ \\
\hline Total & & & 1973 & $\mathrm{Avg}=\mathbf{2 4}$ & 481 & 50403 \\
\hline
\end{tabular}

Note: In cases where data were not reported, estimates were made for capacity and power consumption. 
Table B-3. 1995-1997 U.S. Secondary Steel Mills. Source: I\&SM 1997b.

\begin{tabular}{|c|c|c|c|c|c|c|}
\hline Company & $\begin{array}{c}\text { Plant Location } \\
\text { (City) }\end{array}$ & $\begin{array}{c}\text { Plant Location } \\
\text { (State) }\end{array}$ & $\begin{array}{c}\text { Year } \\
\text { Built } \\
\text { (year) }\end{array}$ & $\begin{array}{c}\text { Age in } 1997 \\
\text { (Years) }\end{array}$ & $\begin{array}{c}\text { Power } \\
\text { Consumption } \\
\text { (kWh/tonne) }\end{array}$ & $\begin{array}{c}\text { Total Nominal } \\
\text { Capacity } \\
\text { (ktonnes/year) }\end{array}$ \\
\hline Avesta Sheffield East, Inc. & Baltimore & $\mathrm{MD}$ & 1995 & 2 & 540 & 136 \\
\hline Birmingham Steel Corp & Seattle & WA & 1995 & 2 & 441 & 680 \\
\hline Birmingham Steel Corp & Memphis & $\mathrm{TN}$ & 1997 & 0 & n.a. & 816 \\
\hline Caparo Stecl & Farrell & PA & 1995 & 2 & 468 & 318 \\
\hline Caparo Stecl & Farrell & $\mathrm{PA}$ & 1995 & 2 & 468 & 318 \\
\hline FirstMiss Steel, Inc. & Hollsopple & $\mathrm{PA}$ & 1995 & 2 & 496 & 91 \\
\hline Gallatin Steel Co. & Ghent & $\mathrm{KY}$ & 1995 & 2 & 441 & 1089 \\
\hline Ipsco, Inc. & Montepclier & IA & 1997 & 0 & 419 & 1134 \\
\hline North Star BHP Steel & Delta & $\mathrm{OH}$ & 1996 & 1 & 331 & 1361 \\
\hline North Star Steel Co. & Kingman & $\overline{\mathrm{AZ}}$ & 1996 & 1 & 468 & 726 \\
\hline Nucor & Berkeley County & SC & 1996 & 1 & 375 & 816 \\
\hline Qualitech Steel Corp. & Pittsboro & IN & 1998 & -1 & n.a. & n.a. \\
\hline Republic Engineered Stcels, Inc. & Canton & $\mathrm{OH}$ & 1995 & 2 & 551 & 118 \\
\hline Roanoke Electric Steel Corp. & Roanoke & $\mathrm{VA}$ & 1996 & 1 & 441 & 454 \\
\hline Slater Steels Corp. & Ft. Wayne & IN & 1995 & 2 & 595 & 73 \\
\hline Stecl Dynamics, Inc. & Butler & IN & 1995 & 2 & 419 & 1089 \\
\hline TAMCO & Etiwanda & $\mathrm{CA}$ & 1996 & 1 & 491 & 499 \\
\hline Trico Steel Corp. & Decatur & $\mathrm{AL}$ & 1997 & 0 & n.a. & 1996 \\
\hline Total & & & 1996 & 1 & $422 *$ & $11,576^{* *}$ \\
\hline
\end{tabular}

${ }^{*}$ Weighted average of furnaces with reported power consumption

** Only reported capacity 


\section{Appendix C. Comparison of Economic and Physical Indicators of Energy Intensity in Steel Production}

Analyses of energy intensity in industrial subsectors can be performed using either economic or physical indicators. Economic energy intensity indicators are expressed in terms of energy use per dollar of economic output (measured as value added, gross output, or value of shipments). Value of shipments includes the receipts for products manufactured, services rendered, and resales of products bought and resold without further manufacture. Value added is defined as a measure of activity derived by subtracting the cost of materials, supplies, containers, purchased fuel and electricity, and contract work from the value of shipments. Gross output is the most comprehensive measure of manufacturing production and includes sales of receipts and other operating income plus inventory change (U.S. DOE, EIA, 1995). Physical energy intensity is defined as the amount of energy required to execute a certain activity (e.g. the production or processing of a specific product) expressed in physical terms.

We compared trends between physical and economic energy intensity indicators for steel production in seven countries (Brazil, China, France, Germany, Japan, Poland, and the U.S.) between 1985 and 1991 (Worrell et al., 1997a). We found that value added based energy intensity indicators tracked the physical energy intensity indicator reasonably well over the study period for the industrialized countries. The correlation between value added and the physical indicator was strongest for Japan, but weaker for France, Germany and the U.S., especially in the later years (Figure C-1 shows the comparison for the U.S.). Value added seemed to bear no connection to the physical indicator for China and Poland, and hence does not seem to be a reliable indicator for both countries. The two value added data points available for Brazil lie close to the physical indicator values, but it is difficult to draw any conclusions regarding trends. The lack of correlation with value added in China and Poland might be due to the pricing of commodities in these countries, which are less dependent on market developments and costs of raw materials.

Energy intensities on the basis of gross output correlate surprisingly well to physical indicators for China and follow trends (but not actual values) relatively closely for Japan and the U.S. (except for 1982 and 1983). Gross output does not track physical developments well in France or Germany, where it is often moving in the opposite direction of the physical indicator trend. Based on these limited observations, we find that energy intensities based on gross output seem less useful as an indicator than value added. Also the correlation with energy intensities based on value added are different, which could lead to different results, as was found in other studies (Ang, 1995).

Value of shipments data were only available for the U.S. and Brazil, and therefore conclusions should be drawn carefully. In both cases, value of shipments data show large fluctuations from year to year which do not follow the physical indicator trends. As with gross output, value of shipments trends are sometimes even moving in the opposite direction of the physical indicators, especially for the U.S. Also, because value of shipments data is not readably available for most countries, the usefulness of this economic indicator is questionable. 
Figure C-1. Comparison of Physical and Economic Energy Intensity Indicators for Steel Production in the U.S., 1985-1991. Source: Worrell et al., 1997a.

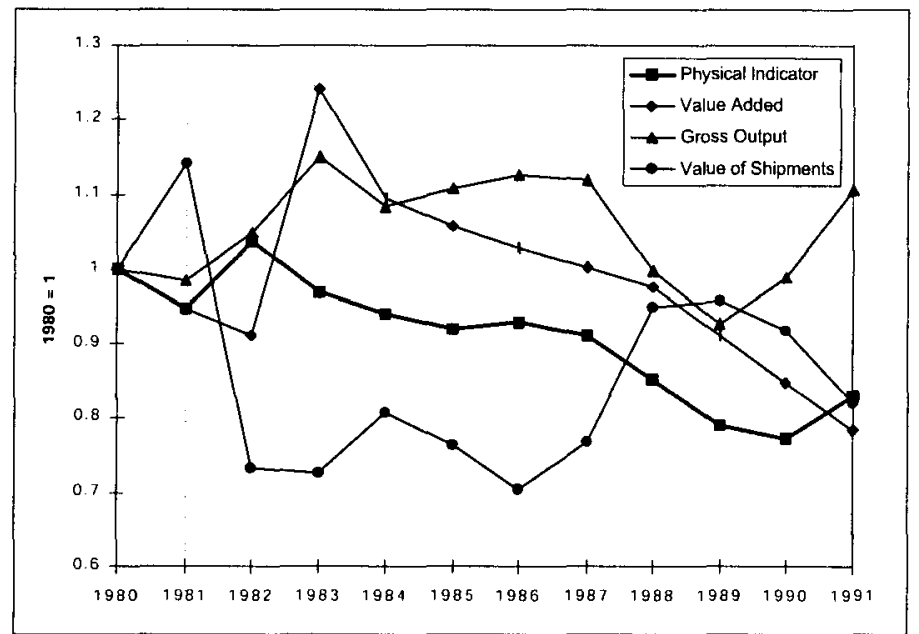

\section{Appendix D. Energy Consumption Estimates for Iron and Steel Production in 1994}

Table D-1 identifies sources for our estimates of energy consumption by process. Estimates were primarily derived from AISI, 1995, Energetics, 1988, Brown et al., 1985, and Bouman, 1983. We believe that future work in this area will require the collection of more up-to-date process energy consumption data for existing plants as well as improved data on general heat and steam loads which are currently unallocated.

Table D-1. Sources for Estimating Energy Use and Carbon Dioxide Emissions by Process in U.S. Steel Production, 1994

\begin{tabular}{ll}
\hline Process Stage & \multicolumn{1}{c}{ Sources } \\
\hline $\begin{array}{l}\text { Integrated Steelmaking } \\
\text { Sintermaking }\end{array}$ & Bouman, 1983 and Dawson, 1993. \\
Cokemaking & AISI, 1995; ANL, 1982; Bouman, 1983; EIA, 1995; Nelson et \\
& al., 1991. \\
Ironmaking & AISI, 1995; ANL, 1982; Bouman, 1983; EIA, 1995; Nelson et \\
& al., 1991. \\
BOF Steelmaking & AISI, 1995; ANL, 1982; Bouman, 1983; EIA, 1995; Nelson et \\
& al., 1991; Steiner 1995; Worrell, 1994 \\
BOF Casting & Brown et al., 1985; Energetics, 1988; Worrell, 1994. \\
BOF Hot Rolling & Brown et al., 1985; Energetics, 1988. \\
BOF Cold Rolling and Finishing & Brown et al., 1985; Energetics, 1988. \\
Boilers & AISI, 1995. \\
Cogeneration & AISI, 1995; EIA, 1997. \\
\hline $\begin{array}{l}\text { Secondary Steelmaking } \\
\text { EAF Steelmaking }\end{array}$ & AISI, 1995; ANL, 1982; I\&SM, 1997; Steiner, 1995 \\
EAF Casting & Worrell, 1994. \\
EAF Hot Rolling & Brown et al., 1985; Energetics, 1988. \\
EAF Cold Rolling and Finishing & \\
Boilers & AISI, 1995. \\
Cogeneration & AISI, 1995; EIA, 1997.
\end{tabular}

Notes

Pelletizing - We note that the production of iron ore pellets is normally undertaken at the mining site and not at the mill. We therefore have excluded energy use for pelletizing in our baseline.

Oxygen - Energy consumed to produce oxygen that is used in the blast furnaces, basic oxygen furnaces, and electric arc furnaces is not included in the calculations. 
Limestone - Carbon dioxide produced during the calcination of limestone when used as a fluxing agent in the furnaces is not included in the calculations. Statistics from the American Iron and Steel Institute show a use of 1,350 ktons of limestone and 3,949 ktons of lime used in steelmaking. We estimate this to be $0.9 \mathrm{MtC}$.

Calculation of EAF Steelmaking Energy Use - The Iron \& Steelmaker annually reports power (kWh/ton) consumption for each electric arc furnace. LBNL calculated a weighted average consumption for 1994 of 436 $\mathrm{kWh} /$ ton (or $480 \mathrm{kWh} /$ tonne).

Iron Alternates - Direct reduced iron (DRI) comprised only 2\% of secondary steel inputs in 1994 (AISI, 1997). Energy use for U.S. DRI production is included in our statistics.

Boilers and Cogeneration - We assume that $80 \%$ of boiler energy use is in integrated steelmaking facilities and that $90 \%$ of cogeneration energy use is also in integrated steelmaking facilities. 


\section{Appendix E. Advanced Technologies for Energy Efficiency Improvement in the U.S. Steel Industry}

In the report we have described technologies that are currently commercially available, or in use in the steel industry in the U.S or elsewhere in the world. Advanced technologies are under development that may affect the long-term trends in energy efficiency in the iron and steel industry. Below we outline some of the major process developments. However, these have not been taken into account in the assessment of the potential for energy efficiency improvement.

\section{Integrated Steelmaking}

Smelting reduction processes are the latest development in pig iron production, abandoning coke preparation. Processes are under development that will also abandon the ore preparation, including CCF, DIOS, AISI, and HISmelt. Currently, only the COREX-process (Voest-Alpine, Austria) is commercial, and operating in South Africa and South Korea, with plants under construction in India, South Korea, and South Africa. In the U.S., Geneva Steel has shown interest in the COREX process. The COREX process uses agglomerated ore, which is prereduced by gases coming from a hot bath. The pre-reduced iron is then melted in the bath. The process produces excess gas, which is used for power generation, DRI-production, or as fuel gas.

Abandoning coke making will decrease capital costs to approximately $\$ 250 / t$ hot metal (compared to $330-350$ for a new blast furnace plant), as well as save energy (Worrell, 1995). The use of steam coal will reduce the coal purchasing costs. The process is inherently cleaner compared to the emissions of the coke oven (Worrell, 1995). The net coal use is estimated to be 15-17 GJ/t hot metal (Worrell, 1995), compared to an estimated 1994 U.S. energy consumption of $18.6 \mathrm{GJ} / \mathrm{t}$ hot metal (U.S. DOE, OIT,1996). The net savings of the (current) COREX process are estimated to be $3.6 \mathrm{GJ} / \mathrm{t}$ hot metal. Investment costs are estimated to be $\$ 250 / \mathrm{t}$ hot metal, with a reduction in operating costs of approximately $\$ 7 / \mathrm{t}$ hot metal (Meijer et al., 1994). Further cost reductions are feasible through abandoning ore agglomeration, currently under development in advanced smelt reduction processes (see below) and a new version of COREX: FINEX using ore fines.

\section{Secondary Steelmaking}

A number of new process designs for the EAF are under development in Europe and Japan. We will only briefly discuss the major developments, stressing that other process might be seen as alternatives as well (e.g. EOF). The processes described here basically use the same concepts as described above (fuel injection, scrap preheating) in a new integrated design.

IHI Process. IHI (Japan) is currently developing a new process consisting of a shaft type preheater with twin electrode DC furnace (Takeuchi et al.,1995; Jones,1997). By using two DC electrodes the heat flux is directed to the middle of the furnace, reducing the heat losses in the furnace walls. Process operation is fully automated. Two pilot/demonstartion plants are in operation in Japan. The process parameters are estimated to be an electricity consumption of $260 \mathrm{kWh} /$ tonne, a fuel consumption of $0.8 \mathrm{GJ} /$ tonne, and an oxygen injection of $33 \mathrm{NM} 3 /$ tonne steel (Jones,1997). The capital costs are expected to be lower than that of conventional DC furnaces due to the higher productivity. No capital cost data were available for this study.

Contiarc process. The Contiarc process is being developed by Mannesmann Demag (Germany). The Contiarc process consists of a continuous scrap smelting process (instead of the current batch process) with a capacity of 1 Mtonnes/year. The design aims to be energy efficient and low emission (Reichelt and Hofman, 1996). The Contiarc process has only been tested in a small scale, and a pilot plant may be constructed soon (Möllers et al,,1997). The designed and expected electric energy consumption is estimated to be $258 \mathrm{kWh} /$ tonne, while injecting 0.25 GJ/tonne steel (Reichelt and Hofman,1996). The production costs are expected to be $\$ 10$ lower per tonne steel produced (Reichelt and Hofman,1996)

Comelt process. The Comelt process (Voest Alpine, Austria) aims at the development of a highly efficient semicontinuous process (Jones, 1997). The process has four graphite electrodes and one bottom return electrode. The whole furnace is tilted to tap the heat. The position of the electrodes enables increased heat recovery as the shaft preheater can be located on top of the furnace. Electricity consumption is estimated to be $307 \mathrm{kWh} /$ tonne, natural gas use of $0.24 \mathrm{GJ} /$ tonne (plus additional carbon use), with an electrode consumption of only $1.8 \mathrm{~kg} /$ tonne liquid 
steel (Jones, 1997). The capital costs of a large Comelt-unit are expected to be equal to that of a DC furnace (Jones,1997), and higher for small capacities. The production costs are estimated to be $\$ 8-10 /$ tonne lower than conventional DC or AC furnaces (Berger and Mittag,1995).

\section{Casting and Rolling}

Strip casting is currently under development in various projects in all major industrialized countries. It takes the direct shaping of steel even further, reducing the need for reheating, and casting thin strip directly. Current experimental casters show positive results, with respect to productivity and product quality. The casters are very small scale, and first installations are believed to have scales smaller than the current thin slab casters. Although developments are proceeding rapidly in this field, we assume that commercial implementation of this technology will not take place before 2005-2010 in the U.S. Energy use data were not found in the literature, but would be lower than that of thin slab casting, as no fuel is needed for the reheating furnace. 